UNIVERSIDADE DE SÃO PAULO

FACULDADE DE FILOSOFIA, LETRAS E CIÊNCIAS HUMANAS

DEPARTAMENTO DE LETRAS CLÁSSICAS E VERNÁCULAS

GUILHERME TAUIL

Vento vadio

Estudo sobre as crônicas de Antônio Maria

VERSÃO CORRIGIDA

Guilherme Nogueira Tauil

Dissertação apresentada ao Programa de pósgraduação em Literatura Brasileira da Faculdade de Filosofia, Letras e Ciências Humanas da Universidade de São Paulo para obtenção do título de mestre em Letras.

Orientador: prof. dr. Augusto Massi

São Paulo, julho de 2020 


\section{GUILHERME TAUIL}

\section{Vento vadio \\ Estudo sobre as crônicas de Antônio Maria \\ VERSÃO CORRIGIDA}

Dissertação apresentada ao Programa de pósgraduação em Literatura Brasileira da Faculdade de Filosofia, Letras e Ciências Humanas da Universidade de São Paulo para obtenção do título de mestre em Letras.

Orientador: prof. dr. Augusto Massi 
Autorizo a reprodução e divulgação total ou parcial deste trabalho, por qualquer meio convencional ou eletrônico, para fins de estudo e pesquisa, desde que citada a fonte.

Catalogação na Publicação

Serviço de Biblioteca e Documentação

Faculdade de Filosofia, Letras e Ciências Humanas da Universidade de São Paulo

$\mathrm{T} 224 \mathrm{~V}$

Tauil, Guilherme

Vento vadio: estudo sobre as crônicas de Antônio

Maria / Guilherme Tauil ; orientador Augusto Massi.

- São Paulo, 2020.

$133 \mathrm{f}$.

Dissertação (Mestrado) - Faculdade de Filosofia, Letras e Ciências Humanas da Universidade de São

Paulo. Departamento de Letras Clássicas e

Vernáculas. Área de concentração: Literatura

Brasileira.

1. Antônio Maria. 2. Literatura brasileira. 3. Crônica. 4. Rio de Janeiro. 5. Década de 1950. I. Massi, Augusto, orient. II. Título. 


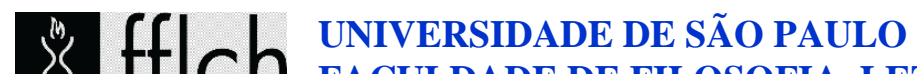

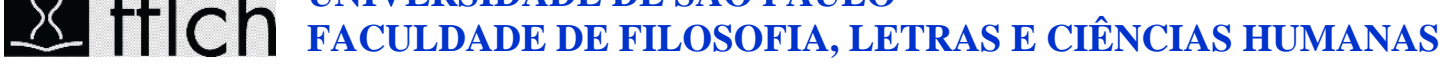 \\ ENTREGA DO EXEMPLAR CORRIGIDO DA DISSERTACÃO/TESE}

\section{Termo de Ciência e Concordância do (a) orientador (a)}

Nome do aluno: Guilherme Nogueira Tauil

Data da defesa: $14 / 09 / 2020$

Nome do prof. orientador: Augusto Massi

Nos termos da legislação vigente, declaro ESTAR CIENTE do conteúdo deste EXEMPLAR CORRIGIDO elaborado em atenção às sugestões dos membros da comissão Julgadora na sessão de defesa do trabalho, manifestando-me plenamente favorável ao seu encaminhamento e publicação no Portal Digital de Teses da USP.

São Paulo, 30/10/2020

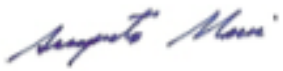




\title{
Resumo
}

Esta dissertação nasceu do desejo de estudar a crônica de Antônio Maria à luz da reorganização de sua obra, atualmente dispersa e fora de catálogo. Embora não se proponha a ser um perfil biográfico, faz uma reconstituição da vida do cronista, corrigindo informações imprecisas de trabalhos anteriores. E, partindo de uma ampla pesquisa de imprensa, reconstitui a trajetória profissional de Antônio Maria por recortes temporais, a fim de dimensionar sua contribuição para a formação do gênero, sobretudo na década de 1950.

Palavras-chave: Antônio Maria, literatura brasileira, crônica, Rio de Janeiro, década de 1950.

\begin{abstract}
This dissertation arose from the desire to study the "crônicas" of Antônio Maria considering a new organisation of his works, which is currently scattered and out of print. Though I do not intend to draw a biographical profile of the author, I will however rely on chronological elements in order to reconstruct the paths of his career. Thus, I seek to take into account his contributions in the formation of the genre, especially in the 1950s.
\end{abstract}

Keywords: Antônio Maria, Brazilian literature, "crônica", Rio de Janeiro, 1950s decade. 
Para Maria Rita,

que só viu o começo. 


\section{Agradecimentos}

A Augusto Massi, professor, editor, mestre.

A Aluízio Falcão, Álvaro Costa e Silva, André Luis Rodrigues, Antonio Prata, Alcides Villaça, Angélica Nogueira, Anthony Trevino, Antônio Maria Filho, Arnóbio Marques, Bárbara Blum, Beatriz Resende, Bia Paes Leme, Bruno Hoffmann, Bruno Mazzeo, Carol Rodrigues, Claudio Leal, Danilo Tauil, Edu Otsuka Teruki, Elvia Bezerra, Eurico Rodolfo, Heitor Nader de Araújo, Helen Garcia Claro, Heloisa Starling, Hermínio Bello de Carvalho, Humberto Werneck, Igor Julião, Ivan Marques, Jane Moraes, Joca Souza Leão, José Trajano, Leda Cartum, Lili Schwarcz, Luis Fernando Verissimo, Maria Lúcia Rangel, Maria Rita Araújo de Moraes, Mauro Nápoles, Milena Varallo, Nelson Caldas, Paulo Roberto Pires, Pedro Henrique Castro, Perfilino Neto, Priscilla Campos, Rafael Gouvêa, Rafael Ireno, Renato Vieira, Roberto Moura, Schneider Carpeggiani, Sofia Nestrovski, Tania Carneiro Leão e Victor Calcagno.

Aos funcionários do Boteco do Gois, do Café Jardin e do Manuê, meus escritórios.

Aos funcionários do Departamento de Letras Clássicas e Vernáculas da Universidade de São Paulo, universidade pública.

Aos funcionários do Arquivo Público de Pernambuco e da Hemeroteca Digital Brasileira, instituições públicas.

Ao financiamento concedido pela Coordenação de Aperfeiçoamento de Pessoal de Nível Superior (CAPES), órgão do ensino público.

Obrigado pelas contribuições diretas. Há ainda todos que ajudaram indiretamente, fundamentais em diferentes medidas. E também os que não atrapalharam, de igual importância.

O presente trabalho foi realizado com apoio da Coordenação de Aperfeiçoamento de Pessoal de Nível Superior - Brasil (CAPES) - Código de Financiamento 001 
Modo de usar

Ao fim da dissertação, a seção "Anexos" traz alguns suplementos importantes. Ao leitor sem intimidade com a obra de Antônio Maria, é recomendável a leitura prévia de "Pequena antologia", que traz a transcrição integral das crônicas analisadas ao longo do estudo. Para os pesquisadores, "Relação de colunas" lista os veículos de imprensa com os quais o cronista colaborou, corrigindo informações biográficas equivocadas. 


\section{Introdução}

1 Antônio Maria, quem diria

\section{Capítulo um}

5 Lembranças de Recife: infância e deslocamento

10 Cachoeira Lisa: mundo perdido

17 Rádio Clube: palavra falada

\section{Capítulo dois}

20 Rio de Janeiro: deslumbre e queda

25 Fortaleza, Salvador: aprendizado e ascensão

\section{Capítulo três}

36 Rio de Janeiro, gosto de você: chegada na capital

39 A noite é grande: nascimento do cronista

47 Menino grande: música e samba-canção

51 Pernoite: cronista noturno

58 Plantão noturno: realização literária

\section{Capítulo quatro}

69 Mesa de pista: alta sociedade

71 Romance policial de Copacabana: submundo carioca

76 Danuza Leão: paixão improvável

79 Diário da Noite: cronista solar

81 O Jornal: de golpe em golpe

\section{Anexos}

91 Relação de colunas

92 Pequena antologia

\section{Referências bibliográficas}


Os homens tristes geralmente fazem graça.

(Antônio Maria)

\section{INTRODUÇÃO}

\section{ANTÔNIO MARIA, QUEM DIRIA}

Ele foi o único cronista de sua geração que não publicou livro. O modo como levou a vida, excessiva e desregrada, sugere uma explicação: trabalhou muito e morreu cedo. No âmago da vida noturna do Rio de Janeiro, se dividia ao mesmo tempo em várias frentes de trabalho, no rádio, na televisão, no jornal e nas boates. A impressão que se tem, ao ler o pouco que se produziu sobre ele, é a de um homem interessado apenas em desfrutar a noite carioca, confiando à posteridade a valorização de sua obra. A ausência em livro seria, então, uma espécie de charme desse personagem enfronhado na boemia, como se tivesse optado por seguir pelas margens. Uma leitura atenta de seus movimentos e de sua obra, no entanto, revela um esforço visível de dialogar com os grandes cronistas. Foi um artista múltiplo que nunca deixou de mirar a realização literária. Marcou intensamente as diferentes linguagens que exerceu: era capaz de escrever crônicas elegíacas e líricas, programas de humor e canções de desamor.

A primeira antologia de crônicas, organizada por amigos, veio em 1968, quatro anos após sua morte. De lá para cá, foram editadas outras quatro compilações e um diário. Embora dê conta de apresentar um cronista singular em seu tempo, apontando uma lacuna na história da literatura brasileira, o conjunto não demonstra a importância da crônica de Maria para a consolidação do gênero na década de 1950. Como seu histórico editorial é feito praticamente por amigos, questões estruturantes de sua obra ficaram pouco expostas, ou mesmo ignoradas. É como se a persona do cronista, que sempre cuidou de se apresentar vulnerável e afetuoso, tivesse demarcado alguns limites para críticos e leitores, que sempre o trataram mais como personagem que escritor.

O primeiro livro, O jornal de Antônio Maria, foi publicado pela Editora Saga em 1968. Com organização de Ivan Lessa, traz apresentações de Vinicius de Moraes e Paulo Francis, além de ilustrações do próprio Maria. O livro ganhou uma segunda edição em 1980, pela editora Paz e Terra, à qual se somou um prefácio de José Aparecido de Oliveira. São 72 textos compilados entre crônicas e aleatoriedades jornalísticas, como pequenas respostas a cartas de leitores dos jornais. Embora graciosas, as respostas não têm valor literário e rebaixam a qualidade do conjunto de sua prosa. O resultado foi certo 
escoamento de sua obra literária, compilada em pé de igualdade a notas avulsas e outras aleatoriedades jornalísticas. Esse comportamento editorial pautou as iniciativas posteriores, ficando evidente que os organizadores de Maria nunca o encararam como um escritor cuja obra fosse capaz de se sustentar por si só.

Outros cronistas, como Rubem Braga e Fernando Sabino, também se valiam de recursos jornalísticos. Drops, pequenos comentários objetivos e a junção de anedotas breves para preencher o espaço do jornal eram estratégias comuns no trabalho do cronista - pressionados, muitas vezes, por colunas diárias. Porém, na transição para o livro, todos revisaram seus textos, alteraram títulos, suprimindo parágrafos, eliminando excessos. Alguns reescreveram crônicas inteiras. Maria, não.

Em 1989, Maria retorna à praça com Pernoite, uma parceria entre a Martins Fontes e a Funarte. O livro, mais uma vez, traz apresentação de José Aparecido de Oliveira. De Vinicius de Moraes, o mesmo texto usado anteriormente mais uma entrevista póstuma. E, por fim, uma nota de Hermínio Bello de Carvalho, coordenador do projeto. As 45 crônicas selecionadas pelos professores Leonardo Castilho e Sônia Mota são do período em que o cronista publicou na revista Manchete. É o melhor projeto editorial sobre Antônio Maria, sem interferências jornalísticas e com fotos do autor. O livro foi lançado junto com um LP, que dava conta de resgatar sua obra musical.

Em 1994, foi publicada uma nova edição da Paz e Terra, organizada por Alexandra Bertola, que assina o posfácio de Com vocês, Antônio Maria. É uma versão ampliada de O jornal de Antônio Maria, com o mesmo paratexto de Vinicius de Moraes e outra apresentação de José Aparecido de Oliveira. Metade dos textos, contando as respostas a cartas de leitores, é de inéditos.

Em 1996, a coleção "Perfis do Rio", parceria entre a editora Relume Dumará e a prefeitura do Rio de Janeiro, publicou um perfil biográfico sobre Antônio Maria. Noites de Copacabana, do jornalista Joaquim Ferreira dos Santos, é o primeiro trabalho biográfico sobre Maria. Talvez pelo recorte da coleção carioca, que perfilou diversas personalidades de outros estados que viveram no Rio, o perfil ignora o passado do pernambucano Maria pelo Nordeste. Desaparecem, assim, aspectos essenciais para a análise de sua obra literária e musical. A limitação de fronteiras sobreviveu à reelaboração do perfil, republicado pela Objetiva em 2006 com o título de Um homem chamado Maria. Revista e ampliada, a biografia continuou ocultando as raízes nordestinas de Maria, como 
se fossem apetrechos na parafernália literária do cronista. Além disso, diversos erros factuais, sobretudo de datas e veículos de imprensa, despistam o pesquisador e desinformam o leitor.

Joaquim Ferreira dos Santos foi responsável pela revitalização de Antônio Maria. Antes da biografia, havia publicado em 2002 O diário de Antônio Maria, um impressionante documento pessoal de grande utilidade ao estabelecimento da vida tão lacunar do cronista. No mesmo ano, organizou pela Civilização Brasileira o volume Benditas sejam as moças, quase inteiramente composto por crônicas inéditas, todas do jornal Última Hora. Em 2005, organizou outro: Seja feliz e faça os outros felizes, com mais vinte textos inéditos.

Somados, os textos publicados de todas as iniciativas dão um pouco mais de 240 . Representam cerca de 6\% da obra de Antônio Maria - quase totalmente dispersa pela imprensa. Períodos de grande realização literária ficaram de fora. Estudá-lo, portanto, demanda um passo para trás. Após exaustiva pesquisa na imprensa fica patente a incompletude das edições de seus livros, sem falar das lacunas biográficas que poderiam fornecer novos caminhos para a interpretação de suas angústias e obsessões.

Relida nessa chave, a obra não realizada de Antônio Maria ganha outra dimensão: não a de um personagem da noite carioca que derramou nos jornais um pouco de seu talento, mas a de um cronista completo e distinto entre seus pares, consumido por inseguranças pessoais que o afastaram da publicação em livro e, a longo prazo, da vida literária brasileira.

Sem pretender ser um perfil biográfico, a dissertação se divide em quatro capítulos, cada um dedicado a um período de vida em ordem cronológica, a partir dos quais se aborda a literatura de Antônio Maria.

O primeiro é dedicado à infância e à juventude de Maria. As lembranças de Recife, memórias da adolescência, o mundo dos engenhos do avô e a reelaboração artística de uma grande experiência de perda. Além das próprias crônicas elegíacas de Maria, que o colocam na linha dos grandes memorialistas pernambucanos, jornais de época serviram como fonte para a reconstituição dos engenhos. A visita ao Arquivo Público de Pernambuco foi fundamental para a pesquisa. 
O segundo trata dos deslocamentos iniciais de Antônio Maria. Em direção ao Rio, onde tentou cortar um atalho para a conquista da vida independente, e depois rumo a Fortaleza e Salvador, onde pôde aprender e amadurecer a carreira de comunicador dentro do império jornalístico de Assis Chateaubriand. Nesse período, aparecem colunas inéditas em livro e não mencionadas em sua biografia.

O terceiro cobre o período de 1948 a 1959. Da chegada definitiva à capital nacional até a sua consolidação como cronista. Por se tratar do período mais conhecido de sua vida, os apontamentos biográficos se restringem ao interesse da análise literária, trazendo à tona momentos fortes de sua prosa, também inéditos em livro.

O quarto, além de pontuar reações imediatas do cronista ao golpe militar, analisa movimentos mais amplos de Maria no fim da vida. Da clausura das boates às calçadas noturnas de Copacabana como repórter policial, da alegria pela paixão improvável por Danuza Leão à depressão do término. 


\section{CAPítulo UM}

\section{LEMBRANÇAS DE RECIFE: INFÂNCIA E DESLOCAMENTO}

Filho de Inocêncio Ferreira de Moraes e Deolinda Diva Araújo de Moraes, Antônio Maria - ou Tombinha, assim chamado por adorar pitomba - nasceu em dezessete de março de 1921. Ao lado dos quatro irmãos, Rodolfo, Maria das Dores, Consuelo e a caçula Luiza, Antônio cresceu num casarão da rua da União, número 9 - a mesma eternizada nos versos de Manuel Bandeira -, num ambiente de conforto e riqueza. O patrimônio acumulado pelo avô materno, Rodolpho Albuquerque de Araújo, figura destacada da elite canavieira, estruturada em torno dos engenhos de cana-de-açúcar, proporcionou às crianças um contato prematuro com o mundo da música e das letras, traço recorrente na formação das elites brasileiras que pressupunha aulas particulares de piano e de francês.

A infância no Recife é um dos tempos fortes da prosa de Antônio Maria. As crônicas em que rememora a terra natal são significativas a ponto de constituir um núcleo importante, destacando uma veia memorialística relevante para a cristalização de seu estilo literário, de natureza abertamente confessional, numa linguagem mesclada de temperos, notações líricas e sociais, pitadas de afeto e de agressividade. "Eram cinco irmãos”, publicada em 26/10/1959, é uma delas:

Eram cinco irmãos, cinco pessoas muito unidas, numa família que vinha de avô muito bom e muito nobre. Acordavam de manhã cedinho, beijavam-se (os mais velhos ajudavam os menores a vestir-se), e sentavam a uma grande mesa de café. Comiam, fartamente, de bolos e de queijos especiais, além de aipins, batatas e inhames, entre goles volutuosos de um gordo, doce e quente café com leite. Depois chegava a professora de piano e, um a um, tomava a lição de todos. Na casa, subindo ao andar de cima (que parecia vazio, de tão grande), repetiam as notas do exercício: dó-mi-sol-ré-mi-ré-dó. $\mathrm{Na}$ rua, os primeiros pregões do cuscuzeiro, do vassoureiro e do homem de "lã-debarriguda".

Lá pelas nove, os cinco irmãos tomavam banho, botavam-se a cheirar de lavanda inglesa e desciam para a lição de francês. A professora: uma mademoiselle de corpo grande e rosto feio. Os olhos e a boca sempre tristes e o nariz vermelho, de bolão. Seu vestido cheirava a roupa que se suava, se guardava, se vestia de novo e nunca era necessariamente 
lavada ou posta ao sol. E, se mademoiselle não tivesse muitos iguais, era sempre o mesmo - preto de meias mangas, uma gola branca passada a ferro, um cinto cinzento com fivela coberta de veludo (preto também), a saia justa nos quadris, indo até os tornozelos. Os sapatos, baixos, de verniz, com uma fivela de adorno, no peito do pé. Começava a aula com uma pergunta direta: Est-ce un livre? E o arguido respondia, fazendo o bico que the era recomendado para evitar a pronúncia norte-brasileira o mais possível e, naturalmente, facilitar a pronúncia francesa: Oui, c'est un livre. Depois, vinha a pergunta falsa. Mademoiselle apontava uma pilha de livros e perguntava: Est-ce que se sont des cahiers? E o arguido com ar vitorioso: Non, ce ne sont pas des cahiers. Ce sont des livres. E mademoiselle, rescendendo o seu vestido negro, ordenava o exercício mexendo a xícara do café, que lhe era trazido, religiosamente, ao meio da lição, por uma criada de avental muito limpo: Escrivez la leçon numéro deux au pluriel - c'est un homme, ce sont hommes etc.

Dos cinco irmãos, um morreu e os outros quatro ficaram pobres. Foram viver cada qual um destino malfadado, envelhecendo e engordando, simplesmente. Escrevem-se nas datas e, antigamente, para avisar o nascimento dos filhos. Não se veem, nem se mandam fotografias, que é para não serem comparados, como no tempo da lição de piano, da lição de francês, da casa, enfim, que hoje é um prédio banal de apartamentos, com farmácia, açougue e lavanderia, nas lojas térreas. $\mathrm{Na}$ rua, não há mais pregões e as manhãs dos domingos perderam aquele ar de imensa felicidade... (1994, p. 45)

Sobretudo nos últimos anos de vida, Maria se debruça sobre a infância como quem estabelece suas memórias - e a memória, como se sabe, "trabalha com a mesma lógica oblíqua e rebelde dos sonhos" (PITOL, 1997, p. 52). Ela contrasta com naturalidade as dádivas do passado com as agruras do presente. Sem estranhamento, imagens contraditórias e ideias opostas se aproximam, tempos e vozes distintas são sobrepostos. $\mathrm{Na}$ crônica, um gênero com tanta facilidade para falar do passado, o tom elegíaco ganha força particular.

A crônica de Antônio Maria tem a característica de resgatar elementos do passado sem anular a voz do presente. Em "Eram cinco irmãos", o cronista evoca detalhes de uma realidade que acena para a completude da infância, quando a vida é simples e o pouco 
basta, mas sem deixar de expor pequenas contradições e estranhamentos de um observador que se soube, desde muito cedo, deslocado no mundo.

A fartura das comidas e a restrição nos costumes, a lavanda inglesa e a lição de francês, o vestido preto da mademoiselle e o avental muito limpo da criada registram um mundo rígido e organizado. Ordem que é desfeita de um parágrafo para o outro, descrita de maneira serena e abrupta: os irmãos empobreceram, envelheceram e engordaram. A apatia e o desinteresse irrompem como consequências naturais da progressiva desordem, que não se restringe à falência da família. A rua, com o fím dos pregões, também perdeu a felicidade, e o imenso casarão do passado deu lugar a um prédio banal de estabelecimentos térreos, pragmáticos e funcionais. ${ }^{1} \mathrm{O}$ espaço público e o privado se fundiram na tristeza.

Assim, a distância afetiva que se instaura entre os irmãos adquire a conotação de uma decadência física e social, derrocada definitiva, perda de uma infância que chegou cedo ao fim. Ou, como no poema de Bandeira, de uma vida "que podia ter sido e que não foi”. Não se trata, porém, da recusa do tempo presente. Maria não costuma desembocar num saudosismo paralisante. Em suas crônicas, a infância geralmente aparece em tinta fresca, não como realidade em que se busca refúgio. O Antônio Maria criança é parecido com o Antônio Maria maduro, o tempo todo reelaborando questões densas sobre amor, afeto, aprendizado, masculinidade e solidão. As observações partem do presente, não desejam recriar o ponto de vista de um menino. É por isso que a professora de francês tem o "corpo grande" e o "rosto feio", a aparência triste e o vestido malcheiroso.

A princípio, Manuel Bandeira, seu conterrâneo, está na origem dessa representação literária a respeito da própria infância. Sobre isso, a observação de Davi Arrigucci Jr. pode ajudar na compreensão do universo lírico de Maria:

De alguma forma [...] o poético pode brotar dessas raízes fundas da infância, de uma terra encantada da memória, pois por vezes as imagens aí sedimentadas se revelam carregadas de uma emoção distinta das emoções comuns, uma emoção imantada, cuja força de atração se traduz em sua capacidade de instaurar um mundo, articulando os

\footnotetext{
${ }^{1}$ Onde hoje se encontra o edifício residencial Sumaré, no número 27, conforme endereço atualizado da rua da União.
} 
elementos mais heterogêneos em torno de seu polo essencial. (2009, p. 203)

Para Bandeira, "o passado [...] não deixou de atuar, inserindo-se no presente como lembrança viva, [...] capaz de, atualizando-se, tornar-se uma forma de percepção do mundo" (ARRIGUCCI JR., 2009, p. 204). Mas, ao contrário da mitologia pessoal e dos alumbramentos do poeta de "Evocação do Recife", é a partir da própria infância que Antônio Maria se descobre à margem do mundo. Essa é uma condição estruturante de sua obra. Em toda oportunidade, descreve-se como feio e gordo, traços físicos que o definem e o situam diante da vida, sobretudo nos relacionamentos afetivos. Essa descoberta, negativa e implacável, se dá quando deixa o ambiente familiar da casa e passa a frequentar o tradicional Colégio Marista, onde foi colega de João Cabral de Melo Neto. ${ }^{2}$ O episódio é evocado em "A mesa do café", de 26/9/1961:

Menino só sabe que é feio, no colégio, quando o padre escolhe os que vão ajudar à missa, os que vão sair de anjo, na procissão, e os que vão constituir a diretoria do Grêmio Mariano.

Eu soube que não era bonito em 1928, no Colégio Marista do Recife. Nunca fui escolhido. Mas sem a menor tristeza, sem concordar até. Aquele julgamento era precipitado, pois (estava convencido) ainda não havia nada de definitivo sobre o bonito e o feio, a beleza e a fealdade. Quais seriam as demarcações? Se não existia a explicação lógica do feio e do bonito, a notícia da minha feiura não me causava mal nenhum. Ao contrário, livrava-me dos tributos que teria de pagar se fosse bonito, ajudando missa e saindo de anjo, à frente das procissões.

Na mesa do café, éramos cinco irmãos. Havia bolo de mandioca, requeijão, bananas fritas, pão torrado e bolacha d'água. Éramos cinco irmãos e, dos cinco, quatro eram bonitos. Vá lá, eu era o feio. Então, por que minha mãe gostava mais de mim? Ela, que nos zelava a todos, que nos conhecia pelo avesso e pelo direito, por que gostava mais de mim? De pena não era, porque pena é uma coisa e amor é outra. Menino

\footnotetext{
${ }^{2}$ Em "As latrinas do Colégio Marista do Recife", recolhido em Agrestes (1985), Cabral registra o atraso moralista do ensino religioso: "Nos Colégios Marista (Recife),/ se a ciência parou na Escolástica,/ a malvada estrutura da carne/ era ensinada em todas as aulas,// com os vários creosotos morais/ com que lavar gestos, olhos, língua;/ à alma davam a água sanitária/ que nunca usavam nas latrinas.// Lavar, na teologia marista,/ é coisa da alma, o corpo é do diabo;/ a castidade dispensa a higiene/ do corpo, e de onde ir defecálo" (1994, p. 524). Ao que tudo indica, ambos foram colegas de José Abelardo Barbosa de Medeiros, o Chacrinha, com quem, mais tarde, Antônio viria a dividir moradia no Rio de Janeiro.
} 
conhece. O gesto complacente, por mais carinhoso, é sempre vacilante e triste. O gesto de amor chega a ser bruto, de tão livre, alegre e descuidado.

Minha mãe gostava mais de mim. Eu sabia, e ela sabia que eu sabia. Em tudo a nossa cumplicidade. Na fatia de bolo, na talhada de requeijão e no sobejo do seu copo d'água. Nossa cumplicidade até hoje existe, quando de raro em raro nos encontramos. [...] Vi-me, então, corajosamente... e não era como gostaria de ser. No coração, um amor tão bonito. Ninguém iria acreditar, mesmo dizendo, mesmo eu explicando, mesmo eu jurando.

Apaguei a luz, tocava o concerto $n^{\circ} 3$ de Beethoven e, no final, apesar do tom ser menor, o lirismo era tão ardente que tudo ficou entendido, entre mim e a minha feiura: eu a amava e não a abandonaria até a morte. (1994, p. 51)

A aceitação da desvantagem física é um ponto definidor de seu universo lírico, marcado por uma perspectiva de ouvinte e repleto de situações autodepreciativas, geralmente calcadas no humor. Como se, para se defender dos outros, fosse o primeiro a se afirmar vulnerável. Essa espécie de poética da falta tem desdobramentos em sua literatura e também em suas canções, e serão abordados mais adiante. Por ora, é importante analisar a figura da mãe, única capaz de desdizer o destino.

A mãe é uma presença marcante no universo do cronista. Nela se reconhece um elemento de valor literário que transcende o registro objetivo, cuja importância ultrapassa o plano biográfico. A elaboração desse personagem parece ter delimitado o mundo masculino de Maria, ajustado em registro passivo, receptor dos carinhos e cuidados femininos: "Minha mãe, coitada, por mais que me amasse, que jeito me daria o seu amor, tão longe estava de mim e de minha miséria?” (1994, p. 40). Essa carência sentimental, que norteia a configuração de sua prosa, é expressa também nos versos antológicos de canções - "Ninguém me ama/ ninguém me quer/ ninguém me chama/ de meu amor" - e num tipo particular de crônica marcada por forte sociabilidade em que se puxa conversa, fala de pessoas, circula em todas as rodas. Daí Maria ser tratado por "o menino grande" e "o bom Maria", apelidos e epítetos pueris.

O pai, por outro lado, praticamente não aparece no romance familiar das crônicas. Pouco se sabe sobre Inocêncio Ferreira de Moraes. A linhagem Ferreira de Moraes 
descende do primeiro matrimônio de Domingos Ferreira de Moraes, senhor de engenho alagoano, bisavô de Inocêncio. Félix Ferreira de Moraes Filho, avô de Antônio Maria, morreu na Batalha do Paraguai e não viu crescerem os dois filhos. A família residia no Engenho do Alto, em Gameleira, próximo a Alagoas, na mata sul de Pernambuco - terras que viriam a ser absorvidas pela família materna de Antônio Maria. Inocêncio era um coronel: participava da vida econômica e política da cidade como fazendeiro, membro de associações comerciais e integrante da comissão executiva do Partido Republicano Conservador de Gameleira. Em 1908, casou-se com Diva, dando início à linhagem de Antônio Maria, os Araújo de Moraes. Para os outros tantos filhos que teve fora do casamento, negou o sobrenome Araújo e o direito à herança.

A ausência do pai nas memórias do filho poderia se explicar, em parte, por sua morte precoce, em 1928, quando Maria tinha sete anos. Mas há, para além disso, uma curiosa aproximação de Maria à família materna. Além da presença constante da mãe, herdou o nome do bisavô, Antônio Maria de Araújo, proprietário de escravos, e fala com devoção do avô Rodolpho Albuquerque de Araújo, dono dos engenhos de Cachoeira Lisa, território fundamental de suas memórias de infância.

\section{CACHOEIRA LISA: MUNDO PERDIDO}

Localizado em Gameleira, ${ }^{3}$ o engenho Cachoeira Lisa foi adquirido nos primeiros anos do século XX pelo avô. Nascido em abril de 1860 no engenho Maravilha, também em Gameleira, Rodolpho Albuquerque de Araújo fez os primeiros estudos na Paraíba, mas graduou-se bacharel na Faculdade de Direito de Pernambuco, em 1884. Começou a vida de agricultor em 1892, e desde cedo esteve envolvido com política. Foi membro do Partido Republicano Democrático e era muito próximo ao general Dantas Barreto, que participou da campanha de Canudos e foi ministro da Guerra de Hermes da Fonseca. Em 1912, Rodolpho de Araújo foi eleito deputado federal pelo primeiro distrito de Pernambuco. Era um dos proprietários do pequeno jornal $A$ Rua. Sempre próximo às instâncias maiores de poder, chegou a representar o então ministro da Agricultura e a se

\footnotetext{
${ }^{3}$ A zona da mata pernambucana foi um dos primeiros espaços brasileiros de atividade econômica, desde o século XVI. Gameleira, como tantas outras cidades, se formou ao redor das atividades e prosperidade dos engenhos. Atualmente, a cidade tem $257,7 \mathrm{~km}^{2}$, 30 mil habitantes e é composta pelos povoados de José da Costa, Cuiambuca e Cachoeira Lisa - os dois últimos, seguramente foram propriedades de Rodolpho de Araújo, que dá nome à principal avenida da cidade.
} 
candidatar ao governo do estado. A cordialidade de seu trato conciliador seria uma solução para a "crise latente entre as diversas correntes partidárias", mas teve a candidatura impugnada por "elementos adversos", conforme noticiou a imprensa, sem mais detalhes.

Como agricultor, expandiu suas terras ao adquirir o engenho Cachoeira Lisa e vários outros no entorno, que foram absorvidos. Investiu em maquinário moderno e elevou Cachoeira Lisa à condição de usina - embora não seja possível precisar sua relevância econômica em relação às outras da região, há registros de que a produção anual saltou de 15 mil para 110 mil sacas de açúcar.

É preciso atentar para a diferença entre usina e engenho. Os primeiros engenhos, que existiam desde o início da colonização do Brasil, eram chamados de banguês. Com numerosos escravos, valiam-se da força animal ou dos rios para a exploração da cana-deaçúcar, resultando num produto de baixa qualidade. No fim do século XIX, os banguezeiros se associaram para enfrentar a concorrência internacional, fazendo surgir os engenhos centrais, com novas técnicas de industrialização e maior poder econômico. Os banguês que não se uniram passaram a tão somente fornecer matéria-prima aos engenhos centrais, que a refinavam com melhor qualidade. Com o aprimoramento de técnicas e do maquinário moderno, muitas dificuldades primárias foram superadas, e então surgiram as usinas, uma evolução capitalista dos grandes engenhos centrais. Com o negócio aperfeiçoado, nasceu a demanda pela renovação completa de toda a estrutura dos engenhos, e assim instalaram-se fábricas diversas, cada uma dedicada a um processo específico, e uma extensa malha ferroviária que integrava todo o processo. Com a expansão das grandes usinas, muitos engenhos menores foram absorvidos e reduzidos à terra para plantio. ${ }^{4}$

Se a primeira usina de Pernambuco foi implantada em 1875, apenas duas décadas antes da modernização de Cachoeira Lisa, é seguro afirmar que o avô de Antônio Maria acumulou um grande patrimônio material. No total, sua usina reunia 29 engenhos de tamanhos variados, sendo Almécegas, Pereira Grande e Cuiambuca os três maiores.

\footnotetext{
${ }^{4}$ Este parágrafo é feito de paráfrases de informações consultadas nas obras da seção "Engenhos e usinas" da bibliografia, em especial ANDRADE, Manuel Correia de. História das usinas de açúcar de Pernambuco. Recife: Fundação Joaquim Nabuco/Massangana, 1989.
} 
Alguns relatos na imprensa, todos de intelectuais ou de homens ligados à estrutura da República Velha, ajudam a dimensionar a imensidão de Cachoeira Lisa, que recebia migrantes de outros estados em busca de trabalho e dispunha de serviços como escola e farmácia. $\mathrm{O}$ artigo do professor Antônio Austregésilo, membro da Academia Brasileira de Letras, publicado no Jornal Pequeno em 10/5/1920, é um exemplo:

Cachoeira Lisa é o reduto de uma família de agricultores adiantados. À frente se acha o dr. Rodolpho de Araújo, prestimoso chefe do dantismo e um dos mais sagazes e progressistas agricultores. A propriedade hoje abrange uma série de bons antigos engenhos, de terras férteis, cortadas de rios, de linhas férreas próprias às usinas, e onde filhos e genros dão o melhor da atividade para progredimento de tão fecundo estabelecimento rural. Nada falta aí: bom plantio de diferente variedade de cana, uma das mais excelentes, bons maquinismos, vasta extensão territorial, gado escolhido e carinhosamente tratado, de raças várias e de espécies diferentes, belos chalés e vilas de moradas, saudável banho de ducha e de imersão, fartura, hospitalidade e espírito sadio, que constituem as fórmulas de Cachoeira Lisa. Fui hospedado por toda a família, dormimos em uma casa, almoçamos noutra, jantamos noutra, proseamos e tomamos café na residência do Rodolpho, palestra magnífica e hospedagem genuinamente nortista. [...] As casas dos filhos e genros do anfitrião são, umas catitas, confortáveis, outras, vastas, todas perfeitamente mobiliadas, atapetadas, cheias de cortinas, de vasos floridos, tudo com o ar risonho e saudável da prosperidade do ambiente. [...] Velhos retratos da família, redes armadas, um piano de mais de meio século, varanda rústica, dão o aspecto grave de uma tradição respeitada.

Em torno da usina, onde passava as férias escolares, Antônio Maria escreve inúmeras crônicas em que revisita a infância, com suas descobertas profundas e povoada por muitos primos. Guiadas por um espírito de aventura entre os vários engenhos da família, as crianças se inserem num universo lúdico de animais e fantasmas, do qual é possível depreender questões de classe e da religiosidade cristã, como consta em "Meus primos", publicada em 25/7/1953:

Nós éramos uns quinze primos feios, quinze loucos e passávamos as duas férias do ano em Cachoeira Lisa, herança do nosso avô honrado, 
uma usina que, em 1924, não devia um tostão a ninguém mas que, em 1946, foi torrada nos cobres por dois vinténs, porque suas dívidas eram terríveis e insustentáveis. Dormíamos num apartamento enorme - sala imensa e um banheiro de bom tamanho e em quinze camas de lona, com um lençol, uma baeta e um travesseiro para cada menino. Cada um tinha sua manta. R. A., por exemplo, adorava caçadas. Um dia the disseram que, na mata do sítio Curuzu, havia uma árvore cujos frutos eram uma comida querida de todos os passarinhos da redondeza. Alguns caçadores, quando anoitecia, iam para lá, deitavam ao pé do tronco, cochilavam e, de manhã cedinho, acordavam com a cantoria dos bichos e cada tiro que davam era uma juriti ou trocaz no embornal. R. A resolveu ir também, mas como era, antes de mais nada, um comodista, levou cobertor, travesseiro, um colchão, candeeiro de querosene e um volume de Os Maias (Eça de Queiroz) para ler, enquanto o sono demorava. Achamos graça em seu equipamento e, à sua saída, ainda perguntamos quando voltaria da África. No dia seguinte, entre oito e nove horas, R. A. deveria voltar com seus passarinhos mortos. Mas deu dez horas, onze, meio-dia e nada. Ficamos sobressaltados e fomos para a mata de Curuzu, um pouco desconfiados que uma cobra ou um gatodo-mato o houvesse apanhado. Procuramos, gritamos seu nome, até que, uma hora depois, embaixo da tal árvore, R.A. dormia como um justo, coberto até o nariz, com o candeeiro aceso e o livro de Eça aberto na página que dizia: "Foi num sábado que Afonso da Maia partiu para Santa Olávia. Cedo, nesse mesmo dia, Maria Eduarda...”. Com o seu comodismo, havia feito uma cama gostosa demais. Leu, adormeceu e, como a friagem da manhã estivesse muito gostosa, dormiu, perdidamente, até uma da tarde, hora em que o encontramos, todo cuspido de passarinho [...]. (1994, p. 36)

O senso de aventura é aguçado pelo apuro geográfico - a amplidão das terras é mesurada pela menção de vários engenhos, e a construção de um universo algo fantástico se faz em torno da evocação das histórias particulares de cada mata, cada morro, todos com nome próprio. O sempre reforçado adjetivo "feio" contrasta com a alegria dos jovens, que estão descobrindo o sexo e o mundo. $\mathrm{O}$ adjetivo soa gratuito, e mais parece a mão pesada do cronista reafirmando sua própria sensação de deslocamento, já que a beleza não desempenha papel estrutural no texto. Outro momento em que se nota uma interferência 
do cronista é no detalhe da citação de Os Maias - a transcrição literal do início do $14^{\circ}$ capítulo é uma disposição de Maria de reelaborar a infância via ficção.

A sugestão vai contra a ideia geral de que Antônio Maria nunca tenha almejado organizar algo de sua obra literária. "Meus primos" faz parte de uma série de crônicas sobre o passado publicadas em 1953 na prestigiosa revista Manchete. Sem dúvida, as memórias representavam um diferencial de grande valor no combate amistoso que travava com a concorrência, formada por cronistas como Fernando Sabino e Sérgio Porto, então colegas de revista.

No fim da vida, Maria volta a publicar mais uma série de relatos da infância pernambucana. E o título de uma das crônicas desvela a ambição do cronista: "Para um possível livro de lembranças”. É preciso atentar para as questões que Maria escolhe expor ao resgatar sua infância, posto que o desconserto irradiado, mesmo que timidamente, revela seu protagonismo nessa espécie de resumo de vida. Isso fica mais perceptível na continuação de "Meus primos":

Primos e primas, seis moças e seis rapazes, resolveram passear a cavalo num engenho nosso, que se chamava Cuiambuca. Saíram de madrugada e prometeram voltar às três da tarde. Acontece que deu sete horas, estava quase escurecendo, e nada deles voltarem. Como era negócio de moças e rapazes, embora primos, as mães ficaram meio assustadas. Eu e Tião, porém, sabíamos que o grupo voltaria são e salvo. Planejamos ir para Volta da Jaqueira, frequentado por fantasmas e almas penadas. Quando os cavaleiros surgissem, Tião, embrulhado num lençol, iria para o meio da estrada e ficaria parado, rezando, aos berros, uma jaculatória pelo repouso dos espíritos desassossegados. Fiquei atrás da jaqueira e quando ouvi o tropel dos cavalos, mandei Tião, com o seu lençol, para o meio do caminho. Nossos primos, tomados pelo susto, em vez de correr, baixaram os rebenques no pobre do Tião, que, durante quinze minutos, apanhava e gritava: "Não tem graça não. Vocês sabem que sou eu". Do meu esconderijo, queria intervir, mas a crise de riso era tanta, que não conseguia sair do lugar.

São estas as pobres e perdidas recordações, embora sem ternura para os outros, de que me sirvo nos dias de saudade. Meus quinze primos, espalhados, desarrumados no mundo (um deles é frade dominicano, em Paris), são hoje, nestas coisas que conto, minha única maneira de voltar 
ao moleque da campina, que não sabia nada e era rei de tudo, para quem o remorso foi uma simples palavra do catecismo, no tempo em que a reza da noite redimia as viagens impossíveis do sexo. Não desprezeis minhas humildes saudades, mas buscai, em vossa meninice, lembranças parecidas com estas e elas vos restituirão um certo apego, um pouco de bem-querer aos dias de hoje, tão sem graça em sua maioria.

O desfecho amargo, sobreposto a instantes de graça e alegria, instaura um cenário contraditório que tensiona a atenção do leitor. A mesma estratégia foi adotada em "Eram cinco irmãos". Assim como os irmãos da crônica já comentada, os primos desta última se espalharam, “desarrumados" pelo mundo. Com eles vão os fantasmas da Volta da Jaqueira, as aves da mata do Curuzu, os cavalos do engenho Cuiambuca. Reminiscências de um mundo que ruiu. A decadência afetuosa, mais do que a degradação financeira, é a verdadeira ausência sentida pelo cronista.

Mas impérios do porte de Cachoeira Lisa não se desmontam repentinamente. $\mathrm{O}$ declínio teve início em dezembro de 1920, com o assassinato de Paulo de Araújo, tio de Antônio Maria e um dos administradores da usina. Aos 29, foi apunhalado por um velho funcionário da casa. O laudo médico assinala quinze ferimentos profundos de faca, e os depoimentos não registram a motivação do crime. Foi o primeiro dos gestores da família a morrer.

Quatro anos depois, em julho de 1924, o avô Rodolpho de Araújo morre aos 64 anos. A causa da morte não foi divulgada pela imprensa, que registrou o cortejo e a despedida numerosa. Familiares, amigos, figuras políticas e da burguesia prestaram homenagens. Dentre os telegramas recebidos, o de Dantas Barreto, marechal e senador da República: "Queiram v. exc. e família acolher expressão minha grande mágoa pela morte eminente amigo Rodolpho Araújo".

Com a morte do patriarca, uma associação comercial de nome Araújo, Dorotheu \& Cia, formada por filhos e genros de Rodolpho, passou a responder pela gestão da usina. Cachoeira Lisa estava ainda no âmbito familiar e funcionaria, por muitos anos, a todo vapor. Mas, de certa forma, a morte do líder acelera o processo de decadência. Gradualmente, a associação foi passando do seio da família para as mãos de agregados e outras associações de usineiros. Em 1928, quatro anos depois da morte de Rodolpho, morrem Mário Rodolpho Araújo, o primogênito, e Inocêncio Ferreira, pai de Antônio Maria. O Diário de Pernambuco registra que Inocêncio morreu aos 45 anos, em sua 
residência, na rua Conde da Boa Vista, 113. "Simples, modesto e inteligente, viveu para a família e o trabalho, esquecido das vaidades do mundo", diz a nota.

Em setembro do mesmo ano, Gil Duarte, um leal agregado da família, publica "Uma lembrança", no Jornal Pequeno:

Quando estive ultimamente em Cachoeira Lisa, uma das coisas que fiz questão de ver foi a casa em que morou Rodolpho Araújo. Encontrei-a ao abandono de sua velhice, marcando ainda o relevo de um grande passado. [...] Debaixo do seu teto cresceu toda a família. Estive, alguns momentos, observando a tela do quadro. As paredes alvas pareciam mudas; naqueles tempos, transmitiam o som e a voz da meninada [...]. Ali mesmo, numa dependência da fábrica, caiu Paulo a golpes de um punhal miserável. Era a desgraçada contribuição da família em favor da indústria; depois, o grande tronco Rodolpho foi vencido pela fatalidade da vida; e depois Mario e depois Inocêncio... Ficaram Luiz e as três irmãs cobertas de preto, a casa velha, abandonada. [...] A grama invadiu o terreiro e a usina viu seu grande nome perder-se no revolver rumoroso do progresso. [...] Hoje, estou jogado no abandono, mas, ainda sou feliz. Vejo todos os dias o rosto de Luiz e outro dia d. Diva esteve aqui, cercada de um rosário de filhos. Só quero que nunca me arranquem deste lugar, enquanto a usina for deles... Não pertencerei a outros donos. Prefiro ruir sobre meus próprios alicerces, caindo como caiu Rodolpho Araújo sobre os braços generosos de seus filhos.

Por volta de 1946, abandonada e endividada, a usina foi vendida. ${ }^{6} \mathrm{O}$ trauma da falência não é uma marca biográfica superficial - na crônica de Maria, a lembrança sempre traz o travo da ruptura e a necessidade de recomeçar. A experiência do fim de um ciclo está presente na obra de diversos romancistas e poetas pernambucanos vinculados ao engenho, que vai se desfazendo no mundo real, mas não em suas memórias - "Algo da estagnação/ dos palácios cariados,/ comidos/ de mofo e erva-de-passarinho./ Algo da estagnação/ das árvores obesas/ pingando os mil açúcares/ das salas de jantar pernambucanas,/ por onde

\footnotetext{
${ }^{5}$ A rua Conde da Boa Vista fica poucos quarteirões de distância da rua da União. Se a família tinha se mudado ou se era um segundo imóvel, não foi possível confirmar.

${ }^{6}$ Curiosamente, o registro mais recente que se tem sobre a usina é a convocatória de uma sessão de alienação judicial em 2018, quando se iniciou o processo de penhora da propriedade, avaliada em $\mathrm{R} \$ 1.830 .958,80$.
} 
se veio arrastando", como no trecho de "Paisagem do Capibaribe", de João Cabral de Melo Neto (1994, p. 107).

Os palácios cariados de Pernambuco permanecem no imaginário de várias gerações de intelectuais e escritores, de Minha formação (1900), de Joaquim Nabuco, a Menino de engenho (1932), de José Lins do Rego. Antônio Maria não leva adiante a linhagem dos homens de sua família. Abandonou o curso de agronomia. Perdeu o mundo que tinha. E com a mesma voracidade com que lhe foi retirada a ordem da vida, irá tentar abocanhar de volta do mundo o que perdeu. Apressado e glutão, tentará subverter o fluxo natural das coisas, renunciando a etapas de formação na tentativa de recuperar, num salto, alguma totalidade assentada. E vai, como é característico de sua geração, aprendendo enquanto faz.

\section{RÁDIO CLUBE: PALAVRA FALADA}

O primeiro trabalho de Antônio Maria foi na Rádio Clube de Pernambuco. Abílio de Castro, radialista importante para a consolidação profissional do rádio no Brasil, era amigo de Mário Rodolfo, primo do futuro cronista e quem o levou para um teste na PRA8 , prefixo da rádio. Foi prontamente admitido, ainda na adolescência. ${ }^{7}$

O rádio, que vivia um momento de grande expansão, era uma possibilidade de realização do ofício da palavra, já que seus trabalhadores escreviam o que seria lido. A atividade é fundamental para a vida de Maria. Além de representar o primeiro contato com o mundo da música, estar diante do microfone marca também sua carreira literária. Maria é o único cronista que ascende do registro da oralidade e de um saber ao vivo, instantâneo e efêmero - traços caros à crônica.

Pouco se sabe dos primeiros anos de atuação de Maria na Rádio, por onde passaram, em diferentes períodos, artistas como Chacrinha, Chico Anysio, Capiba e o maestro Nelson Ferreira. Há registros de que tenha trabalhado como speaker, se envolvido com locução de futebol, programas de música e produção de radionovelas. A

\footnotetext{
${ }^{7}$ Embora algumas fontes apontem que Maria tenha começado aos dezessete anos, a maioria afirma que foi aos treze, incluindo Paulo Mendes Campos, em elaborado perfil publicado na Manchete, em que registra "depois do curso ginasial, o primeiro emprego na rádio". O início precoce se explicaria pela necessidade financeira do desmanche da usina.
} 
impressão é de que Maria foi se expandindo junto com a emissora, praticando os diferentes gêneros conforme eram assimilados à grade.

Precursora do rádio no Brasil, a Rádio Clube de Pernambuco foi fundada por um grupo de amadores. O Jornal do Recife anunciou, em 7/4/1919, a fundação da primeira rádio clube do país "sob os auspícios de uma plêiade de moços que se dedicam ao estudo da eletricidade e da telegrafia sem fio". A estação experimental dispunha de aparelhos construídos pelos próprios usuários, "para a transmissão sem fios do pensamento humano". Segundo Renato Phaelante, "não se pensava em radiodifusão propriamente dita àquela época, até porque somente a 2/11/1920 se inaugura a primeira estação de radiodifusão nos Estados Unidos, a KDKA da Westinghouse". ${ }^{8}$

Em termos oficiais, a primeira transmissão radiofônica massiva se deu no Rio de Janeiro, em 1922. Instalado no Corcovado por uma empresa norte-americana, um transmissor de 500w levou a oitenta residências o discurso do presidente Epitácio Pessoa e a ópera $O$ guarani, de Carlos Gomes, como parte da comemoração do centenário da Independência. No ano seguinte, o antropólogo Edgar Roquette-Pinto fundaria a Rádio Sociedade do Rio de Janeiro, a primeira emissora legalizada do Brasil.

Muitos pesquisadores reclamam o pioneirismo de Recife, uma vez que a Rádio Clube de Pernambuco já funcionasse com um pequeno transmissor de $10 \mathrm{w}$. Não surpreende que a capital do país tenha sido mais ágil em legalizar e estruturar uma emissora propriamente dita, mas é certo que a cultura do rádio em Recife tinha um papel estruturante na organização das artes, do poder público e da sociedade no geral.

Em 1923, com o aporte financeiro do usineiro João Cardoso Ayres, pai do pintor Lula Cardoso Ayres, a Rádio Clube de Pernambuco se reorganizou e passou a transmitir palestras e música instrumental ao vivo. A instalação de transmissores modernos fez com que a Rádio Clube funcionasse em ondas curtas, ampliando as atividades e atraindo novos locutores, radialistas e músicos que ficaram desempregados com a chegada do cinema falado. Em seguida, o jornalismo - isto é, a leitura de artigos publicados na imprensa passou a integrar a programação.

\footnotetext{
${ }^{8}$ Para mais detalhes do estudioso Renato Phaelante sobre a fundação da Rádio Clube de Pernambuco e do rádio, conferir BESSA, Silvia. "Rádio Clube, a pioneira do Brasil, comemora 100 anos". Diário de Pernambuco. Recife, 06 abr. 2018.
} 
Um dos primeiros gêneros da rádio a se consolidar foi a locução esportiva, em meados dos anos 1930. Em torno do futebol, criou-se uma estrutura profissional de grande interesse popular - os repórteres de campo e os comentaristas de intervalo tinham surgido recentemente, nas transmissões de profissionais como Ary Barroso e Oduvaldo Cozzi, na capital federal. Os jogos eram transmitidos de maneira precária, de qualquer lugar do campo que comportasse a pequena equipe. É justamente como speaker futebolístico que Maria se destaca no início de sua carreira - segundo o colega de escola João Cabral de Melo Neto, Maria "se transformou em locutor esportivo para se consolar de seu fracasso como goleiro". ${ }^{9}$ Com bordões originais, a narração de Antônio Maria se vale de uma forte característica presente em todos os seus trabalhos, da comunicação à literatura: o humor.

Mas Recife era pouco para o coração ambicioso de Maria. Aos dezenove anos, em março de 1940, atendendo ao chamado de Fernando Lobo, seu melhor amigo de infância, pega o ita Almirante Jaceguai com destino ao Rio de Janeiro. Era um jovem se aventurando na capital em busca de emprego, cumprindo o rito de tantos outros nordestinos. Mais do que isso, era o movimento do menino em direção ao mundo grande, a fim de reconquistar de imediato a vida estabelecida que tinha perdido.

\footnotetext{
${ }^{9}$ O registro é de Rubem Braga na coluna "Gente da cidade", em que perfilava personalidades e artistas. "João Cabral, poeta" foi publicado à página 58 da edição da Manchete de 27 de novembro de 1954. Cabral, segundo Maria, jogava de meio-campo recuado.
} 


\section{CAPÍTULO DOIS}

\section{RIO DE JANEIRO: DESLUMBRE E QUEDA}

Maria desembarca na capital com pouca mala, alguma experiência de rádio e um grande desejo de conquista. Conta com o amparo dos colegas que por lá já estavam estabelecidos. Sem chegar a formar um grupo articulado como o dos mineiros, os nordestinos (e não somente os pernambucanos) se ajudavam e se fortaleciam profissionalmente.

Seu primeiro endereço é o apartamento 1.005 do edifício Souza, na rua do Passeio, Cinelândia, próximo ao cinema Palácio e ao café Nice. No apartamento moravam o pernambucano Fernando Lobo, o baiano Dorival Caymmi e o alagoano Teófilo de Barros, pai do letrista Théo de Barros. "Não havia lugar para ninguém, mas o gordo [Antônio Maria] se ajeitou. Trouxera ternos novos, camisas variadas, e até um chapéu de feltro que jamais usou e que um dia virou bola de futebol no pequenino apartamento" (LOBO, 1991, p. 28).

O amigo maranhense Henrique de La Rocque, futuro deputado federal, arruma emprego de speaker para Maria na Rádio Ipanema (PRH-8), atual Rádio Contemporânea. Cobrindo o locutor baiano Erik Cerqueira, afastado para tratar uma tuberculose, o jovem Maria é anunciado como Araújo de Moraes, formalidade que destoa de seu estilo bemhumorado e debochado de narrar futebol. Seus bordões, que trouxera da Rádio Clube de Pernambuco, estavam em situação de impedimento, à frente de seu tempo. Sobre isso, o jornalista Joaquim Ferreira dos Santos dedica as primeiras páginas do perfil biográfico Um homem chamado Maria:

O Rio de Janeiro de 1940 já estava confuso. Demole-se o morro de Santo Antônio, ampliam-se os jardins da Glória, inventa-se a Esplanada do Castelo. Muita poeira. E aquela narração do speaker recém-chegado de Pernambuco não ajudava nada a clarear as coisas. Os senhores ouvintes levariam ainda muitos jogos para compreender que "bola no fotógrafo", expressão inventada por Maria, queria dizer que o atacante simplesmente chutou para fora. [...] "Bola com Romeu Pellicciari, que passa por Domingos da Guia, por Pichin e chuta. Entrou de guardachuva aberto" - descrevia Araújo diretamente do estádio da Gávea, certo de que todos entenderiam. Tratava-se de um gol espetacular, feito com tal facilidade pelo craque que ele se dava ao conforto daquela 
proteção. Havia uma tentativa de bossa, mas o sotaque, o chiado da transmissão, a novidade da coisa, nada ajudava. (2006, pp. 21-2)

O emprego dura apenas seis meses: "Queria muito ser poeta e sou speaker esportivo. Speaker esportivo, com sotaque, e só até o dia em que Erik Cerqueira sarar dos pulmões" (1980, p. 104), escreve num diário que aproveitaria em crônica uma década depois, já ressaltando o obstáculo que o sotaque pernambucano representou.

Apesar do distanciamento apontado entre ser poeta e ser speaker esportivo, é possível dizer que, diante do microfone, Maria encontrou alguma realização do ofício da palavra. Escreveu os textos de seus programas como quem escreve crônicas: sempre para o dia seguinte, com regularidade estabelecida e com o descarte imediato pressuposto. $\mathrm{Na}$ carreira de locutor de futebol, esses traços são menos possíveis, mas outros se realçam. $\mathrm{O}$ locutor precisa desenvolver uma fala de sedução. Sua palavra circula entre todos, os analfabetos inclusive, e demanda um apuro de observação, de simplicidade e de inventividade, traços fundamentais para o cronista moderno. Assim como no jornal, era preciso conquistar o público pela palavra.

Pouco depois, Teófilo de Barros e Dorival Caymmi, os nordestinos mais velhos que já tinham carreira iniciada, deixam o apartamento para os novatos. Responsáveis pelo aluguel, Lobo e Maria passam aperto. Chegam a roubar comida de vizinhos e dos cabarés, onde contam com a solidariedade das dançarinas, que lhes facilitam o acesso à cozinha. "O dinheiro daria justo se não tivéssemos um destino boêmio a cumprir: pelo menos aos sábados soltávamos nossos passos no Dancing Avenida, para depois cairmos nos braços das moças" (LOBO, 1991, p. 28). Somado à angústia financeira, o comportamento inconsequente dos jovens faz com que tenham dificuldade de estabelecer residência.

Com outros nordestinos que se juntaram à empreitada, como o pintor Augusto Rodrigues e Abelardo Barbosa (o futuro apresentador Chacrinha), são expulsos de prédio em prédio. Primeiro, se mudam para o edifício Orânia, na rua Ronald de Carvalho. Depois para o edifício Othon, no cruzamento da rua Viveiros de Castro com a Duvivier, e, por fim, para o edifício Andraus, na avenida Nossa Senhora de Copacabana. Espécie de república de estudantes, festas e encontros eram comuns no apartamento. Em certa ocasião, uma das dançarinas do Dancing Avenida ligou do apartamento para a polícia e disse que havia sido sequestrada. Maria chegou a ser preso por uma noite. O episódio está relatado na crônica "A senha do sotaque", de 1953: 
Faltavam uns oito dias para o carnaval de 1941 e eu entrava, sem paletó, sem moral e sem camisa, segurando as calças com as mãos, num compartimento úmido e fétido da Polícia Central do Rio de Janeiro. Os outros presos batiam samba em latas de goiabada e cantavam uma toada, que dizia: "aquela que me acompanhava na minha jornada partiu para onde, eu não sei". ${ }^{10}$ A água fria que, de 10 em 10 minutos jogavam na barriga da gente (para acalmar), escorria no cimento lodoso, misturada a feijão, a restos de carne, a urina e fezes. A cadeia estava cheia demais e ao procurar um cantinho onde pudesse me acocorar, era ameaçado pelos olhares dos que haviam chegado primeiro. Ai de mim se pisasse alguém. Acocorei-me, afinal, entre um mulato e um brancoso e comecei a tomar conhecimento da minha situação. Vi-me só, esquecido, ignorado e inúteis eram todos os bens que pudessem me querer. Minha mãe, coitada, por mais que me amassse, que jeito me daria o seu amor, tão longe estava de mim e de minha miséria? Minha namorada, tão aflita que sempre tinha sido em relação às minhas artes, por mais telefonemas que desse, jamais saberia de mim. Meus amigos outra coisa não podiam fazer, além de ficar tristes, trancados num apartamento do Edifício Andraus, esperando notícias e pedindo a Deus que eu chegasse antes deles. Naquele exato momento, compreendi a grandeza do homem que tem de valer por si mesmo, pela sua dor, pela sua desproteção e, sentindo a imensa coragem dos desvalidos, os meus olhos, que vieram suaves e mansos, se tomaram do mesmo ar de desafio, da mesma arrogância, que havia nos olhos dos meus irmãos, assassinos e ladrões. Podia haver o que houvesse e minha dor não teria gemidos, podiam me dar de chicote até eu virar ferida e não diria a ninguém que parasse. Foi quando rangeu o cadeado da porta de grades e disseram meu nome por extenso. $\mathrm{O}$ mulato à minha direita, palpitou por conta própria: "acho que vais apanhar". Eu também achava. Mas, quando me vi no corredor, lado a lado com o guarda que me viera buscar, o destemor era tão grande, o desapego da vida era tão frio e real, que lhe disse já em tom de briga: "na hora de bater, bata em lugar que mate; ou, então, bata longe". O policial parou de repente e me fez parar,

10 "Partiu... para onde não sei”, samba de Felisberto Martins e Henrique Mesquita, gravado por J. B. de Carvalho em 1940: “Ai, não posso mais sofrer/ Ai, não posso mais amar/ Aquela que me acompanhava na minha jornada/ Partiu para onde não sei/ Por que vou chorar/ Se eu nunca chorei?// Quem souber chorar/ Venha me ensinar/ Que eu quero aprender/ Pra desabafar/ Esta dor que me faz sofrer/ Dores eu sinto demais/ Não sei chorar/ Mas ai dos meus ais". 
também, segurando-me pelo cós das calças. Olhou-me com ódio e eu o olhava com desprezo. Estávamos há cem anos de olhos pregados um no outro, quando veio um guarda de talabarte e perguntou o que era que estava acontecendo. Tirou os olhos de mim e respondeu: "nada. É o preso que está querendo cigarro". Meteu a mão no bolso e ofereceu cigarros Liberty. Tirei um, botei atrás da orelha e continuamos andando.

Uma hora depois, eu tinha sido solto e estava na rua, sem saber que caminho ia tomar. Por um desses raros e importantes acasos da era de Filinto Müller, ${ }^{11}$ ninguém tinha me batido. Então, o mesmo guarda, que eu pensei que fosse um mau sujeito, estava me esperando na esquina. Disse que, da outra vez, eu fosse menos valente e, quando soube que eu morava em Copacabana, deu-me vinte mil réis para ir de táxi. Tinha sotaque de pernambucano. (1980, pp. 35-7)

Publicada no Diário Carioca, a crônica ganha corpo à medida em que realiza aspectos biográficos no registro literário. $\mathrm{O}$ primeiro pensamento que acomete o cronista, depois de averiguar a situação, é reconhecer-se só. Apartado dos outros, "inúteis" seriam "todos os bens" que pudessem lhe querer. Posta com tanta certeza, sua autovalorização é indicativa da busca implacável pelo afeto alheio. O cronista sabe bem o lugar que ocupa, ou que deseja ocupar, no universo afetivo dos outros. Antes de lamentar a própria situação, lamenta a impossibilidade de receber o carinho. Os adjetivos utilizados pressupõem o outro: "só, esquecido, ignorado". E a figura da mãe reaparece ao lado de outros dois grupos constantes no mapa afetivo de Maria, compondo uma espécie de santa trindade: os amigos e a mulher.

Estar sozinho é algo que evitou toda a vida, de modo que o isolamento ganha um ar definitivo de superação. Por isso sente-se grande ao compreender que precisa valer por si só, pela "sua dor" e "sua desproteção" - "desproteção", aliás, é o adjetivo singular que faz a crônica se multiplicar em significados, evocando o sentimento de desmonte da infância. De que outra desproteção, de que outra dor poderia falar um jovem de dezenove

\footnotetext{
${ }^{11}$ Filinto Müller foi chefe da polícia política de Getúlio Vargas. Prendeu e torturou arbitrariamente. Foi um dos responsáveis pela deportação de Olga Benário Prestes, grávida, à Alemanha nazista. Entre 1969 e 1973 , foi senador e presidente do Arena, partido de base da ditadura civil-militar. A citação a Müller é indício da consciência que o cronista tinha da tortura como prática recorrente da polícia, o que intensifica ainda mais o entrave com os guardas.
} 
anos, com amigos, mãe e namorada, vivendo na capital, senão a dor de um passado? O seu referencial de dor é a experiência da ruína familiar.

Num ambiente desprotegido, aprende a adaptar-se rápido, e a lição é sobretudo masculina: "Sentindo a imensa coragem dos desvalidos, os meus olhos, que vieram suaves e mansos, se tomaram do mesmo ar de desafio, da mesma arrogância, que havia nos olhos dos meus irmãos, assassinos e ladrões". Não foi a primeira vez que Maria precisou enrijecer. Já trazia consigo algo da estrutura do abandono. Sutil, é pelo olhar, e não pelos atos, que o jovem observador se irmana aos outros presos - o que não deixa de ser um certo modo de não estar só.

Em ritmo crescente, a crônica arma uma expectativa de violência, com o recrudescimento físico, o rangido do cadeado e o palpite do presidiário: "Acho que vais apanhar". A disposição do cronista para a briga aparece em sua postura, com o olhar fixo nos olhos do policial que o chama, e em sua fala: "Na hora de bater, bata em lugar que mate". A tensão entre os olhares dura uma infinidade e só se quebra com a chegada de um terceiro, um guarda. A este, o primeiro policial nada quis delatar, desarmando a possibilidade da violência com a entrega de um cigarro, ironicamente chamado Liberty. E, de repente, o agressor em potencial se torna um aliado. A reviravolta inesperada de papéis só se revela no bote da última frase: "Tinha sotaque de pernambucano".

O sotaque funcionou como senha para que se reconhecessem os conterrâneos. A fala ressignificou a agressividade em camaradagem. Sinal de identidade, o sotaque traz à tona o disfarce adotado pelos nordestinos na capital, deslocados e destoantes. Um sofrimento invisível que o policial entendeu de imediato e soube ocultar de todos. A cumplicidade exibe várias camadas, com a entrega do cigarro, o dinheiro para o táxi e o conselho de proteção, dado somente do lado de fora da delegacia, para que da próxima vez fosse menos valente. Uma irmandade silenciosa e quase subterrânea.

Sobretudo em seus primeiros anos, Maria era tratado na imprensa como "o nordestino", “o pernambucano", “o nortista" e até mesmo "o baiano". Apesar da grande quantidade de nordestinos desempenhando papéis importantes, sobretudo na indústria artística do Rio, o preconceito era palpável. O sotaque, se funcionou como senha no presídio, era uma espécie de contrassenha na vida profissional de Maria, representando uma das barreiras que dificultaram seu estabelecimento como locutor na Rádio Ipanema e, a rigor, a conquista da vida que almejava. 
Derrotado e humilhado, Maria retorna ao Recife ainda no início de 1941. Parece mesmo que o jovem Antônio Maria tinha pressa em reconquistar um mundo que perdeu e, diferente do usual, trocou a fase de aprendizado na Rádio Clube de Pernambuco pela sedução de vitória na Rádio de Ipanema. Atrapalhou-se e perdeu o rumo. Sua carreira de radialista fica marcada primeiro por uma experiência de queda, e só depois, maduro e assentado, viverá a ascensão. Foi preciso parar, regressar para casa e reorganizar os planos.

\section{FORTALEZA, SALVADOR: APRENDIZADO E ASCENSÃO}

De volta ao Recife, Maria retoma o trabalho na Rádio Clube de Pernambuco. Se por um lado a experiência juvenil na capital, manifestação de um desejo de conquista reparatória, representou um atraso em sua carreira, por outro, fez com que absorvesse novas referências. Abílio de Castro, radialista responsável por sua contratação anos antes, disse em depoimento:

Antônio Maria era um colega nosso, $[\ldots]$ foi para o Rio e encontrou essa moda de camisa slack, esportiva. Quando voltou, trouxe uma camisa esportiva e foi entrando no estúdio assim. Eu disse: "Olha, rapaz, acaba com isso, vai botar uma camisa social, gravata e paletó". Oscar [Moreira Pinto, proprietário] disse: "É, vá vestir-se. No meu estúdio, só entra de gravata e paletó”. Antônio Maria voltou para casa, foi pegar a gravatinha, a camisinha, o paletozinho e voltou para trabalhar. (apud BESSA, 2018)

Esse frescor pode ter sido um aliado importante da necessidade de reorganização que Maria sentiu após a frustração no Rio de Janeiro. Assim, Maria amplia suas atividades, todas encerradas no ofício da palavra, passando a trabalhar também com redação de propaganda e publicando suas primeiras crônicas avulsas na imprensa. Em crônica de 1961, "Vigésimo aniversário", rememora sua experiência inicial:

Comecei no Recife, em abril de 1941, via pistolão, após receber de volta onze crônicas que entreguei, pessoalmente, ao secretário do jornal. Fui publicado, afinal, descrevendo uma mulher que vira na Rua Nova e que face a ela me colocara "com a humildade de um mendigo diante de um prato de comida". A imagem fez muito sucesso entre quatro ou cinco 
amigos, na calçada da Fênix, em Recife. Mas foi só. À noite, quando fui levar a segunda crônica, o secretário trancou-se comigo em seu gabinete e passou-me este carão:

- A Norma Shearer (havia-lhe elogiado o "estrabismo lascivo de Norma Shearer") de quem você falou é esposa de um anunciante nosso, que mandou suspender o anúncio da edição de domingo. Você, hoje, tem que escrever qualquer coisa explicando que a semelhança de sua personagem com qualquer pessoa é mera coincidência.

Depois:

- Já vi que você quer ir no caminho de Rubem Braga. Mas fique sabendo que, em cidade pequena, isto é impossível.

Segui dali para a frente tomando imenso cuidado com qualquer coisa que pudesse desgostar o anunciante. Na mesma crônica de estreia, a revisão me atingira pela primeira vez. Corrigira "mendigo" para "mendingo". Na do dia seguinte, sobre carnaval, saiu "sempertina". Em vez de "serpentina". Pensei muito em abandonar o jornalismo. Por dois motivos: o anunciante e a revisão [...]. (2003, p. 71)

Ainda que não tenham sido localizadas tais primeiras crônicas, é possível afirmar que a iniciação de Maria na literatura se dá em um período de amadurecimento do gênero, que passou por um importante desenvolvimento na década anterior. Antonio Candido, ao analisar as mudanças sociais da década no célebre ensaio "A Revolução de 1930 e a cultura", aponta o papel de eixo catalisador do movimento de outubro, em torno do qual muitos elementos culturais dispersos se reconfiguraram em novos significados fenômeno possível porque afloraram, também, condições materiais e culturais da polvorosa década de 1920. A "rotinização" das novidades culturais, impulsionadas por novas condições econômico-sociais e novas correlações entre sociedade e Estado, se deu em diversos setores: “instrução pública, vida artística e literária, estudos históricos e sociais, meios de difusão cultural como o livro e o rádio (que teve desenvolvimento espetacular)" (2011, p. 220).

A educação pública viveu um momento de raro esclarecimento e, numa renovação pedagógica liberal, passou a pretender formar o cidadão. As ideias libertárias que culminariam na criação da Universidade de São Paulo norteavam as reformas do ensino. No âmbito religioso, o catolicismo também se renovou, com a criação da Ação Católica 
e sua atuação nas favelas cariocas, atingindo setores não religiosos. De maneira similar, a vida política, com a consciência social impulsionada pelas experiências agitadas do mundo, impregnou a intelectualidade brasileira de modo geral. Assim, assistimos tanto ao engajamento espiritual e social de artistas e intelectuais católicos que tomaram gosto “pela pesquisa da 'essência', o ‘sentido', a ‘vocação', a 'mensagem', a 'transcendência', o "drama", quanto à impregnação de conceitos marxistas por ensaístas e prosadores, não necessariamente comunistas, como "'luta de classes', 'espoliação', 'mais-valia', 'moral burguesa', 'proletariado', ligadas à insatisfação difusa em relação ao sistema social dominante" (CANDIDO, 2011, pp. 228-9).

Esse caldo de novidades impactou a literatura, já marcada por inovações temáticas e formais do Modernismo. No que diz respeito à crônica, houve um grande salto qualitativo, principalmente em função de dois eixos: o literário, com a realização e a atualização do ideário modernista, e o material, com a consolidação da indústria brasileira dos meios de comunicação. A crônica acompanhou a evolução da imprensa, que passou a ocupar papel central na vida urbana.

A trajetória de Rubem Braga, o mais relevante dos cronistas, só foi possível com a expansão dessa indústria, que, ao difundir a crônica por um público amplo e de vários estados, permitiu que o cronista, diferente dos prosadores tradicionais, vivesse da literatura que pingava no jornal. No ímpeto desenvolvimentista de um país que queria se descobrir e se construir, a literatura de jornal encontrou espaço para amadurecer, experimentar e se transformar. Cronista passou a ser profissão.

Uma década antes, em 1924, o paraibano Assis Chateaubriand fundava os Diários Associados, então o maior conglomerado de jornais, rádios e, posteriormente, televisões. Primeiro comprou O Jornal, do Rio de Janeiro, e em seguida o Diário da Noite, de São Paulo. A trajetória profissional de Antônio Maria está diretamente associada à expansão dessa indústria. A modernização da imprensa é um dos muitos frutos da "mentalidade mais democrática a respeito da cultura, que começou a ser vista, pelo menos em tese, como direito de todos, contrastando com a visão de tipo aristocrático que sempre havia predominado no Brasil" (CANDIDO, 2011, p. 235). Não à toa, a missão declarada dos Diários Associados era "promover a integração do Brasil pela palavra escrita".

Foi nesse cenário que Rubem Braga se consolidou como cronista nacional. É sintomático pensar que apenas cinco anos após ter estreado com $O$ conde e o passarinho, 
Braga já fosse referência a ponto de, em 1941, o jovem Antônio Maria ouvir do editor do jornal que deixasse de tentar seguir o caminho de Rubem Braga. ${ }^{12}$

O editor se referia a certa maneira nova de fazer crônica, que subvertia o que pudesse haver de objetivo para transformá-lo em subjetividade, exprimindo experiências num veículo que "quer liquidá-las, substituindo-as pela pura informação" (ARRIGUCCI JR., 1999, p. 152). O ponto de partida do cronista era um olhar frequentemente melancólico, muitas vezes reflexivo e sempre detido sobre o instante - pois mesmo superando seu originário caráter documental, a crônica nunca deixou de falar sobre as questões e a gente do seu tempo. Tudo isso norteado por uma linguagem simples e um profundo interesse pelas pessoas e pela vida comum, o que abriu espaço para aflorar o "senso modernista do momento poético" (ARRIGUCCI JR., 1999, p. 154). Mais ou menos estabelecida pela pena de um homem com "uma certa emoção do interior", a crônica moderna, nas mãos de Rubem Braga, ganhou ar definitivo de conversa gratuita, um modo peculiar de se postar diante do mundo, de prosa meio desconversada sobre qualquer coisa que, de repente, vira algo maior, com significados densos ditos de maneira insuspeitamente corriqueira.

É certo que Braga parte de uma crônica já marcada pela experiência das ruas, pelo manejo gracioso e inventivo da língua mesmo quando na dureza parnasiana, e que ainda aperfeiçoaria sua própria técnica nas décadas seguintes; mas muitas dessas características já tinham corpo em 1936, com seu primeiro livro. Se compararmos o tom braguiano com alguns textos de Carlos Drummond de Andrade em Confissões de Minas, que reúne escritos de 1925 a 1944, ou mesmo com Crônicas da província do Brasil, de Manuel Bandeira, publicado em 1937, é possível notar um descompromisso de Braga com o corte ensaístico que marca os dois livros mencionados. Mais do que isso, a crônica moderna praticamente recusa os conhecimentos formais na medida em que ganha feição mais bem delineada, o que contribui com a sua transformação em mercadoria nos anos seguintes, quando passa a ser veiculada no rádio e publicada em livro com maior frequência.

Para compor Confissões de Minas, Drummond valeu-se de formas variadas que vão do diário ao ensaio crítico, da simples descrição à crônica de fato - uma indefinição

\footnotetext{
12 Braga tinha passado por Recife de maio a setembro de 1935, onde colaborou com o Diário de Pernambuco e editou a Folha do Povo, porta-voz nordestina da Aliança Nacional Libertadora, onde publicou crônicas. Há mais informações sobre o período em CARVALHO, Marco Antonio de. Rubem Braga: um cigano fazendeiro do ar. São Paulo: Biblioteca Azul, 2013.
} 
de gêneros em que a proximidade com um tom geral da crônica se faz notar pela "experiência pessoal objetivada, que se desvia da intimidade para a esfera pública e incorpora, ao cabo, a consciência de uma época" (MARQUES, 2011, p. 363). A crônica e o ensaio, que proliferaram na cultura modernista, são gêneros dos quais se espera, muito mais do que dos outros, uma relação com o tempo - marca fundamental da experiência moderna e da própria noção de modernidade.

Se a crônica ganhou sustança crítica e reflexiva com o caldo concentrado do Modernismo, desenvolvendo-se tanto pelos princípios estéticos quanto pela consciência ideológica - resultado, segundo João Luiz Lafetá, da pressão que a problemática política e social exerceu na consciência estética (2000, p. 38) -, era de se esperar que, nos anos seguintes, o gênero deixasse quase por completo a sua conexão com o noticiário para se dedicar a possibilidades mais literárias. A crônica já tinha acúmulo interno suficiente para tomar o caminho que a levaria para o que é hoje, um espaço de possibilidade do etéreo terreno, em que o cronista está livre para versar o que quiser, valendo-se de quaisquer recursos narrativos ou poéticos, mas geralmente sem perder o vínculo com a realidade e com sua herança da oralidade. Sem pressupor leitor especializado, ela quer ser lida até por quem se detém no caderno imobiliário. Daí o caráter lúdico e a linguagem leve, quase como para convencer o leitor a adentrar um caminho mais denso embora nunca tortuoso, do qual sairá com alguma sensação não disponível em nenhuma outra página do jornal. Uma experiência, portanto, de subjetividade.

Com o amadurecimento literário do gênero, é possível notar certa experimentação, talvez inconsciente, de seus limites imprecisos e elásticos nos anos seguintes. Em torno da crônica, formou-se um grupo diversificado de escritores com traços autorais bastante distintos, o que ampliou as possibilidades formais do gênero e foi deixando para trás uma convenção antiga de classificar qualquer texto jornalístico em primeira pessoa como crônica. Nesse grupo, Antônio Maria desempenhará um papel importante na década de 1950, como veremos adiante.

Alguns anos antes, ainda em Recife, após ter publicado crônicas esparsas, Maria tem sua primeira experiência de assinar uma coluna fixa, "Irradiações", na Folha da Manhã, de fevereiro a março de 1944. Publicada aos domingos, inédita em livro e sequer mencionada em sua biografia, a coluna revela um profissional do registro oral que passava, pouco a pouco, também para o registro escrito. "Irradiações", como o nome sugere, trabalha com elementos do universo do rádio, e serve, basicamente, como 
publicidade para seu programa semanal, o Vitrine, que consistia em transmitir apresentações musicais feitas ao vivo no palco do cinema Boa Vista, com músicos locais e os que estavam de passagem, como Nelson Gonçalves, que causou frisson ao se apresentar para a sociedade pernambucana. O programa apresentado por Antônio Maria ia ao ar às quartas-feiras, às $16 \mathrm{~h}$, contava com patrocínio de marcas comerciais e, para quem quisesse assistir ao vivo, a entrada custava apenas dois cruzeiros.

Embora não possam ser chamados propriamente de crônicas, os textos de "Irradiações", exibiam uma prosa graciosa que incorporava elementos da vida cotidiana do Recife. Por servir de base naval para o bloco dos Aliados na Segunda Guerra, a cidade vivia um momento de grande agitação, recebendo diversos estrangeiros. A impressão é a de que Maria nunca coube em uma coluna objetiva de jornal, e mesmo quando se restringe a fatos e notícias, arruma um jeito de escapar com o leitor pelas ruas da cidade.

Antônio Maria havia estruturado sua vida: programa próprio na rádio, salário suficiente e planos de casamento com Maria Gonçalves Ferreira, a Mariinha, filha de Candido Ferreira Cascão, proprietário da usina Pirangy. Fernando Lobo, já estabelecido no Rio de Janeiro como profissional da música e da comunicação, triangulava com os Diários Associados um cargo para o amigo na Ceará Rádio Clube, recém-adquirida pelo conglomerado de Assis Chateaubriand e precisando de reformulação. Em carta a Lobo, Maria manifesta seu desejo de crescer e a consciência de que a passagem pelo Ceará seria um momento de aprendizado, uma etapa necessária para que pudesse retomar seu objetivo de viver na capital do país. Não se trata mais de um arroubo de juventude, mas de um plano estratégico:

Recife, 28 de fevereiro de 1944

Você, agora, mais do que nunca, precisa ser meu amigo. O seu convite e as suas bases, diante da boa situação que construí aqui, deixaram-me em um angustioso estado de susto... Vejo bem as vantagens da sua proposta. Vêm ao encontro do que eu quero. Com a confiança que deposito em mim, vejo perfeitamente que a minha estada no Ceará será transitória, uma rápida viagem para aí: a finalidade. Não posso também esconder a minha satisfação diante da oportunidade de dirigir, à minha maneira, com o nosso jeitão. Você precisa considerar as cifras que passo a discriminar: 
Ordenado de rádio: $\mathrm{Cr} \$ 1000,00^{13}$

Programa Vitrine, transmitido do cinema Boa Vista, com publicidade contratada por mim e ingresso a "dois cruzeirinhos": Cr\$2000,00

Redação de publicidade da Malharia Imperatriz: Cr\$200,00

Como redator de uma seção na Folha da Manhã: Cr 200,00

Há também um cachê de Cr\$100,00 quando - coisa raríssima - aparece por esta terra um jogo de futebol...

Estava com casamento marcado para esses dias. Para sair daqui, sairei casado, e, fora daqui, preciso de um mínimo de Cr\$2000,00. Não deixe que a oportunidade desapareça para mim, pois não quero perdê-la. Estamos, eu e Mariinha, animadíssimos. Responda com urgência. ${ }^{14}$

Em março, Maria se casa com Mariinha, dando continuidade à lógica dos matrimônios entre a aristrocracia de engenho, ainda que ressignificada. Não demora para conseguir o cargo de diretor artístico em Fortaleza. É o primeiro degrau dentro dos Diários Associados, que, após consolidar sua liderança na imprensa escrita, passou a investir nas rádios do Norte e do Nordeste. No começo da década de 1940, o grupo já havia adquirido rádios no Piauí, Bahia, Natal e Paraíba. Em janeiro de 1944, comprou a Ceará Rádio Clube (PRE-9). A contratação de Maria se encaixava nos planos de expansão do império midiático dos Diários. E aos 23 anos, o jovem pernambucano recomeçava a pôr em prática seus planos de reconquistar o Rio de Janeiro.

A passagem pelo Ceará é um período obscuro de sua trajetória profissional. Além de ter participado de uma novela de rádio como par da atriz Laura Santos, o pouco que se sabe da breve temporada foi narrado pelo próprio Maria na crônica "Fortaleza de Nossa Senhora d'Assunção", publicada na Manchete, em 12/09/1953:

Lá passamos todo o ano de 1944, um comecinho de 45 e teríamos ficado para o resto de vida, se não fosse o telegrama "western", que dizia: "siga Bahia”. [...] Os melhores recantos residenciais são: Aldeota (bairro de

\footnotetext{
${ }^{13}$ Segundo o decreto-lei 5977, de 1943, o salário mínimo corrente era de Cr\$380,00. Maria recebia, então, algo em torno de nove mínimos.

${ }^{14}$ Esta é uma das poucas cartas preservadas de Maria. Foi transcrita para o encarte do disco Antônio Maria, fascículo 36 da coleção "História da música popular brasileira", cujo texto foi revisto e republicado em 1978, na coleção rebatizada de "Nova história da música popular brasileira". Há outras cartas no acervo de Dorival Caymmi, sob a guarda do Instituto Antonio Carlos Jobim, assim como oito cartas trocadas com Vinicius de Moraes, nos aquivos da Fundação Casa de Rui Barbosa, ambas no Rio de Janeiro.
} 
casas modernas), a praia de Iracema - se o mar ainda não a engoliu por inteiro - e todo o caminho do Benfica, ${ }^{15}$ onde o casario é mais sisudo e o silêncio da noite ajuda uma grande paz para quem foi dormir em estado de graça. [...] Se chove, o distinto é vestir um calção ou desvestir-se completamente e ir tomar a chuva nas costas, aos gritos de alegria, com uma cachacinha antes e outra depois. As famílias se visitam muito, quase sempre após o jantar e, com as cadeiras na calçada, ficam horas e horas adivinhando invernos [...]. (MARIA, 1989, pp. 43-

4)

Fortaleza representa um armistício. Maria fala da cidade com prazer, como um turista fazendo recomendações a um amigo. As imagens e as palavras evocam felicidade: grande paz, silêncio da noite, dormir em estado de graça. "De um jeito saudoso, quero bem a Fortaleza, a loura desposada do sol!", conclui. A alegria contrasta com a abordagem agridoce do Recife de sua infância, quando a frustração e a violência convivem com as brincadeiras de criança. Trata-se de outro período de vida: o começo da própria família e de uma promissora carreira no rádio. A passagem de Recife a Fortaleza só guarda um traço em comum com a aventura juvenil vivida no Rio de Janeiro: a necessidade de recomeçar a vida fora de casa.

No início de 1945, Maria é transferido para a Rádio Sociedade da Bahia, em Salvador, também do grupo de Chateaubriand. Era uma emissora maior, de prestígio. De início, mora numa pensão do Largo Dois de Julho, próximo ao endereço da rádio, situada na rua Carlos Gomes, 57. A promoção proporciona um grande momento de consolidação profissional. Como diretor artístico, sem deixar de transmitir jogos de futebol, Maria reorganiza toda a grade. Uma de suas iniciativas memoráveis são os concursos de música para cantores e compositores, que lançaram, entre outros artistas, o sambista Batatinha. ${ }^{16}$

Em 1947, a imprensa já trata Maria como “o locutor número um da Bahia”. Nesse período, publica uma coluna breve sobre futebol no jornal Cidade do Salvador, de nome

\footnotetext{
${ }^{15}$ A família viveu em uma casa na rua Joaquim Magalhães, no bairro do Benfica. Sobre o período na cidade, o cronista publicou também "Fortaleza-Ceará", na Manchete, em 16/5/1953.

${ }^{16}$ A história está contada em entrevista a Fernando Faro para o programa MPB Especial da TV Tupi, de 1974. Batatinha relata o incentivo que Maria lhe deu para tomar parte em seus concursos, quando ainda era um compositor sem confiança. Foi Maria quem o batizou, parodiando o nome artístico de Vassourinha, jovem cantor paulistano. Maria também foi responsável pelo início da carreira individual do sambista Riachão. Em entrevista a Claudio Leal, o compositor relata que se apresentava na Rádio em dupla, com um amigo, pelas manhãs. Um dia, o amigo bebeu demais e não pôde se apresentar. Riachão reportou a situação a Maria, seu diretor. A resposta mudou a vida do sambista: "A partir de hoje você vai trabalhar sozinho", decidiu Maria.
} 
"O comentário de Antônio Maria". O título é significativo de uma maturidade profissional: é a primeira vez que Maria usa seu próprio nome como marca, algo que vai levar vida afora sobretudo nos jornais, como se a exposição de seu nome evocasse um estilo próprio.

A essa altura, já era pai de seus dois filhos, Maria Rita e Antônio Maria Filho, que nasceram em Recife - os pais fizeram questão de que assim fosse. Mais do que a tranquilidade familiar em Fortaleza, Salvador representa um momento de plenitude e aparece com frequência em suas crônicas. Lá, conhece amigos fundamentais, como Odorico Tavares, diretor de grande importância para os Diários Associados, e se aproxima de Jorge Amado, Carybé, Carlos Pena Filho e outros artistas e intelectuais. É possível dizer que, em Salvador, Antônio Maria acumulou bagagem e construiu a ponte para o salto definitivo em direção à capital. Estava se preparando para se transformar no Antônio Maria da década de 1950.

“Bahia, galinhas \& festas”, da mesma série memorialística de 1953, é uma das crônicas em que evoca o contentamento de Salvador:

É com imensa saudade de coisas e pessoas, que vamos falar da "galinha do Manoel”, a melhor comida de toda São Salvador. Até hoje, ninguém pôde fazer uma ideia de como aquelas maravilhas são preparadas e quem cometeu a ingenuidade de pedir receitas, voltou ignorando-a mais do que nunca, tão hábil é o despistamento do proprietário desse bar triste, onde nada é especialmente romântico, nada foi projetado, mas onde aconteceu tanta coisa da Bahia. Vem uma travessa imensa e são seis ou oito galinhas, nadando em molho gordo e escuro. A padaria ao lado, cúmplice desse misterioso assado, mandou o pão estalante e quentinho que, daqui a pouco, estará enxugando a graxa gostosa de um prato que precisa ser batizado. Com Odorico Tavares, num domingo de não fazer nada, resolvemos chamá-la de "Galinha ao Mobiloil 40" e foi assim que a apresentamos a Aníbal Machado, Rubem Braga e à moça Tônia Carrero, que vinham da Europa e ficaram conosco (Anísio Teixeira também estava) durante dois dias, enquanto a estiva, preguiçosa e politizada, prendia o Poconé $e^{17}$ no cais. Se Deus ainda me

\footnotetext{
17 A classe de estivadores de Salvador era muito mobilizada e representativa, com sindicato próprio. Episódios de greve e retenção de navios cargueiros como o Poconé eram comuns. Assim como na nota anterior de Filinto Müller, a menção ao episódio de conflito demonstra que o cronista estava sempre consciente de questões sociais, podendo dizer muito a partir de uma simples referência.
} 
quiser na Bahia, nem que seja por umas horas, eu quero ir buscar uma porção de saudades naquele canto da Barra. Quero, também, pagar os 300 mil reis que eu devo ao Manoel - única fatura baiana que não liquidei, quando vim de lá, em abril de 48 . Se alguém está de viagem marcada para esses dias, em Salvador, encontrará duas festas - a da Aleluia e a do Espírito Santo, no domingo de Pentecostes. De passagem pela barra, será um crime perder a "galinha do Manoel", feita sem dendê, sem pimenta, sem nada da tradicional comida afro-baiana, mas, boiando naquele molho, cuja receita ninguém obterá jamais. A rua e o número eu nem me lembro. Mas, fica ali defronte do mar, perto do farol, atrás do edifício Oceania, quase na esquina onde se cruzam e dobram os bondes de Barra e Barra Avenida. É só perguntar, que todo mundo ensina. [...] Gente pacata, a da Bahia. A incomparável doçura do povo rende os nove dias da Conceição da Praia, sem uma cena de sangue, sem uma briga de sopapo. Discutir discutem, porque quem é baiano tem que bater boca a vida inteira. Mas, nada de estragar a roupa e a pele do outro. No Recife, em festas mais humildes (só de barraquinhas de prendas e carrosséis), a confusão era tanta e depois de certa hora, exército, polícia e povo se entendiam tão pouco, que o jeito era o tiroteio. Feliz de quem pode estar na Bahia, a 8 de dezembro, e assistir a uma Conceição da Praia. Noite e dia, o zabumba comendo, o povo cantando, dançando e, como anotou o samba de Caymmi: "o sol está queimando, mas ninguém dá fé”. (1989, pp. 19-20)

A comida está sempre associada aos momentos de maior deleite, seja nos cafés da manhã da infância no Recife, seja nas melhores lembranças das mesas que dividiu com amigos no Rio. Mas nada se compara ao relato gastronômico da galinha do Manoel, que, ao lado das festas populares, é pilar estrutural da crônica. Em Salvador, Maria é acolhido e acolhe os amigos. Tempo de fartura culinária e festas religiosas que tomam conta das ruas. Contrastam com as festas de Recife, atravessadas pela violência e pelos tiroteiros. Quando lembra de Pernambuco, detém-se sobre o que perdeu. No Ceará e na Bahia, fala de coisas que conquistou - o sentimento final é de dádiva e gratidão. ${ }^{18}$

\footnotetext{
${ }^{18}$ Esta crônica faz parte de um conjunto de seis publicadas na Manchete, entre março e abril de 1953, todas com o subtítulo "Bahia": "Antiquários e praça", "Candomblés e pais de santo", "Comidas", "Galinha \& festas", "Oradores" e "Oradores e tipos populares", esta encerrada com a declaração "Mais revista tivesse a meu dispor e cem dessas histórias seriam contadas, intactas em minha lembrança, com o testemunho do povo baiano" (MARIA, 4/4/1953).
} 
Como homem de destaque dos Diários Associados, chegou a concorrer ao cargo de vereador, o que revela disposição de se manter em Salvador. A campanha foi pelo ralo quando, pouco antes da eleição, reagiu a uma provocação agredindo o cidadão Jacaré, popular alcóolatra que emprestou o apelido da marca de uma cachaça local. Segundo Maria, o motivo da rusga foi sua naturalidade pernambucana, o que o impossibilitaria de exercer o cargo no entendimento de Jacaré. O registro aparece em crônica de Arthur Carvalho:

Conheci Antônio Maria nos anos 40, irradiando jogos em Salvador, pela PRA-4, Rádio Sociedade da Bahia, no lendário alçapão da Graça. Ele inovou a maneira de transmitir as partidas - e uma vez disse que Bengalinha, half do Vitória, tinha saído de campo "manquitolando". Menino de calça curta, eu jamais ouvira aquele verbo, o que muito me impressionou. Com prestígio entre os intelectuais da Boa Terra, o Menino Grande discutiu com Jacaré, tipo popular do Mercado Modelo, e deu-lhe uma bofetada. Desgastado com o episódio, tomou um Ita no Norte e foi brilhar no Rio de Janeiro até morrer de amor. (2015, p. 372) A ida para o Rio, no entanto, nada tem a ver com o episódio da bofetada. Trata-se de um movimento progressivo de conquista. Depois de derrotado em sua primeira tentativa, retornou para casa e tomou o caminho de aprendizagem, acumulando experiências. Em abril de 1948, Maria vai para o Rio de Janeiro com trabalho garantido nos Diários Associados. ${ }^{19}$ Já tem um nome e, como convidado, não precisa mais entrar pela porta dos fundos.

\footnotetext{
${ }^{19}$ Uma nota jocosa de $O$ momento, jornal do Partido Comunista da Bahia, comemora a saída de Maria: "O sr. Antônio Maria emigrou novamente. Não pôde permanecer por mais tempo na defesa dos interesses do imperialismo ianque nesta praça: as vaias eram frequentes. Muda o comércio para o Rio" (18/4/1948). O comentário acentua sua posição de destaque nos Diários Associados. Não é exagero dizer que Maria deve seu estabelecimento como cronista a Assis Chateaubriand, também um nordestino com desejo de conquista, e com quem Maria preservará um vínculo profissional até o fim da vida.
} 


\section{CAPÍTULO TRÊS}

\section{RIO DE JANEIRO, GOSTO DE VOCÊ: CHEGADA NA CAPITAL}

Aos 27 anos, Maria chega à capital com a família. Estava encarregado da direção artística de duas rádios: a prestigiosa Rádio Tupi, primeira emissora dos Diários Associados, e a Rádio Tamoio, recentemente adquirida pelo grupo de Chateaubriand, onde trabalhavam futuros talentos como Walter Clark e Chacrinha. A Rádio Tupi era a segunda em audiência, perdendo apenas para a Rádio Nacional. Dentre seus contratados, estavam nomes como Carmen Miranda, Ary Barroso, Luiz Gonzaga, Dolores Duran, Dalva de Oliveira e Dorival Caymmi, que saúda a chegada do amigo em sua coluna em O Jornal:

Para essa série de inovações nas duas associadas [Rádio Tupi e Rádio Tamoios] foram mobilizados outros elementos de organização para a realização desse trabalho maior. Assim é que já está comandando artisticamente as duas emissoras, Antônio Maria Araújo de Moraes, que veio da Rádio Sociedade da Bahia, após ter criado pacientemente uma rádio que hoje tem sido apontada como forte na capital baiana. [...] A presença de Antônio Maria na direção das duas irmãs associadas traz no ambiente de rádio uma esperança de renovação. (13/5/1948)

Caymmi foi o primeiro a falar detidamente de Maria na imprensa carioca. Mais velho e já estabelecido no Rio, Dorival acolhe o amigo num gesto paternal de uma amizade que dura toda a vida. O compositor é assunto recorrente na obra do cronista, sempre vinculado a momentos de afeto e simplicidade. De certo modo, Caymmi transparece como exemplo para Maria. É provável que estudos comparatórios entre o cancioneiro de ambos encontrem influências do baiano, para quem, anos mais tarde, Maria escreveu: "Deixa que me orgulhe e me sinta mais gente pela ventura de contigo ter andado, de mãos dadas, por caminhos duros ou macios, em horas de riso ou de tristeza" (1989, p. 57).

Ainda sem a popularidade que ganharia nos anos seguintes, o novo diretor artístico das emissoras é apresentado pelo nome completo. Os registros indicam que atuou como apresentador, animador, entrevistador e locutor de futebol, além de ter feito contribuições como roteirista de programas humorísticos e musicais. "Locomotiva capaz de puxar toda uma composição de atividades fatigantes", como descreveu Paulo Mendes Campos, envolvia-se por completo em tudo que fazia. É difícil classificá-lo como homem de rádio que também atuou na televisão, ou como cronista de jornal que também se envolveu com 
rádio. Trata-se de um profissional do ofício da palavra em sentido amplo, e agora disposto a se firmar como cronista, ambição ausente de sua primeira empreitada pelo Rio.

Desde o fim de 1948, Antônio Maria assina "Rádio", uma pequena coluna em $O$ Jornal, carro-chefe dos Diários Associados. Ela fazia parte da seção “Artes e espetáculos", voltada à programação artística da cidade. Notas pequenas, de caráter informativo, davam pouca margem para o desenvolvimento de uma individualidade. Não se trata, ainda, de crônica. Mas representam uma consolidação da indústria cultural, ferramentas dadas aos cronistas (e aos aspirantes) para desenvolverem vozes próprias.

Se nos primórdios da imprensa no século XIX a crônica disputava leitores dentro do folhetim, um espaço voltado ao lazer e responsável "pelo ingresso de temas até então alheios aos grandes jornais" (SOARES, 2014, p. 74), restritos a interesses econômicos e políticos da

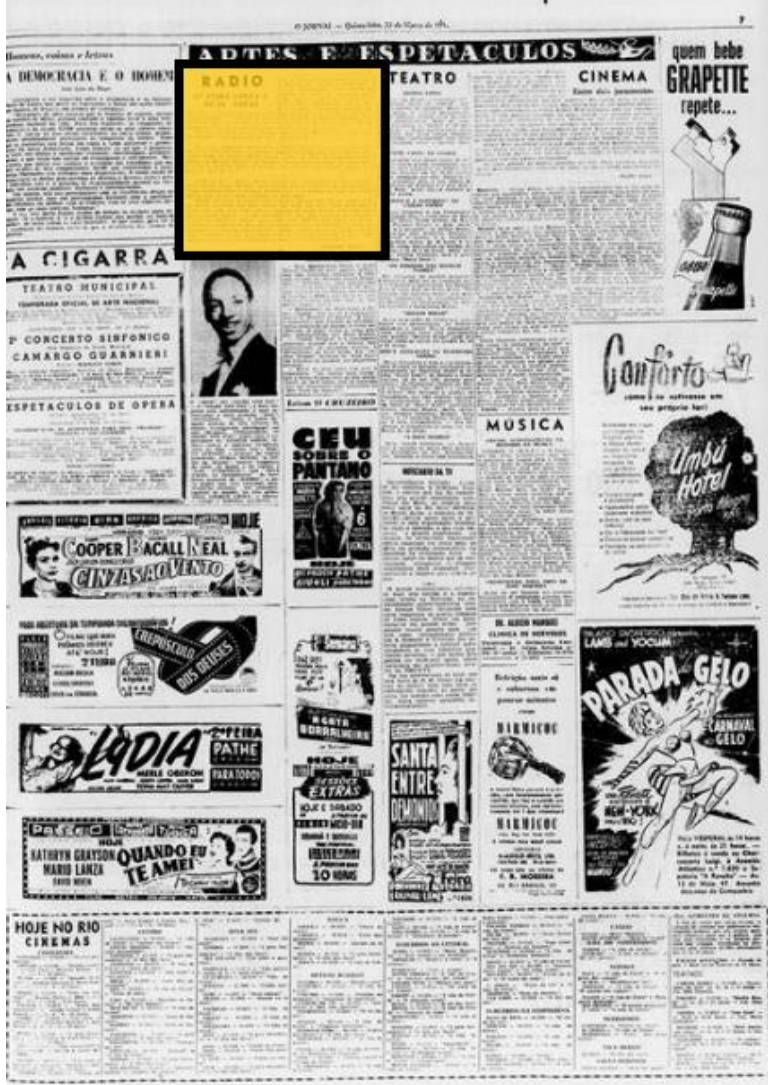
burguesia, na década de 1950 a crônica vai disputar espaço dentro da própria indústria cultural. Com ela, surge na imprensa a necessidade de uma cobertura cultural rápida, nascendo a figura do colaborador mais ou menos especializado, sem função bem estabelecida, que aparecia pelas beiradas e flertava com espaços reservados à crônica por exemplo, Antônio Maria escrevendo sobre rádio e Sérgio Porto sobre música. Além disso, a cobertura jornalística da vida cultural desobrigou a crônica de abordar tais assuntos, fazendo crescer a possibilidade do lirismo no gênero.

O estabelecimento de seções multifacetadas dedicadas às artes nos jornais, algo próximo do que se conhece hoje por um caderno cultural, abriu espaço a esses colaboradores com vocação literária camuflada. No caso de Maria, foram mais de mil dias de "Rádio". Embora ainda fosse uma abordagem prática do universo do rádio, com notícias, críticas e uma tímida dimensão de subjetividade, soube buscar um tratamento diferenciado de linguagem e manifestar certa inclinação à narrativa. $\mathrm{O}$ cronista estava prestes a acontecer. 
Maria é, afinal, o único caso de cronista que vem de baixo para cima. Sobretudo na década de 1950, quando a nova estrutura social permitiu que escritores ganhassem sustento com a publicação de crônicas, muitos autores praticaram o gênero. Alguns migraram do registro da poesia, como Manuel Bandeira, Carlos Drummond de Andrade, Vinicius de Moraes e Paulo Mendes Campos. Outros, do campo da prosa, como Mário de Andrade, Rachel de Queiroz e Fernando Sabino. Rubem Braga, cria do próprio jornal, é um caso particular e logo ascendeu à condição incontestável de "escritor puro-sangue". Maria, por outro lado, surgiu do registro da oralidade, do mundo do rádio. Talvez essa tenha sido uma das razões que o fizeram duvidar durante anos do próprio talento.

De fato, da nova geração, era o escritor com menor bagagem literária. Mas soube tirar proveito da sociabilidade artística que fervilhava no Rio de Janeiro, convivendo com todo tipo de gente nos cafés e nas boates no contexto de formação de uma estrutura cultural. As categorias profissionais ainda não estavam compartimentadas pela especialização. E essa intensa vida social possibilitou à geração desgarrada do pós-guerra uma boemia viva e misturada. Os grupos reuniam compositores, escritores, cantoras, poetas, pintores, atrizes, editores e jornalistas.

Assim, a crônica, gênero fronteiriço entre jornalismo e literatura, acabou por absorver elementos de outras linguagens. Da música popular, por exemplo, incorporou algo de seu ritmo, sua oralidade, sua cadência leve e seu arcabouço simbólico, de modo a ampliar a paleta de cores dos cronistas. ${ }^{20}$

No caso de Maria, que viria a se tornar um profícuo compositor, fica evidente a aproximação com o mundo musical, que contribuiu com a formação de escritores mais populares e menos literários. A vida social em torno da música nutriu sua obra. Como radialista, tinha construído a importância de seu nome na cena musical. Paralelamente, se esforçava em aprofundar sua relação com a literatura por intermédio do jornal.

\footnotetext{
${ }^{20}$ Embora representasse também um certo conflito social, a relação dos cronistas modernos com a música popular é bastante estreita. Surge no final da década de 1920 com Orestes Barbosa e entronca com Vinicius de Moraes, figura central e da maior comunhão entre as linguagens. Manuel Bandeira, da geração anterior, embora tivesse mais conexão com a música erudita, também compôs letras populares, como "Azulão", em parceria com Jayme Ovalle e um samba com Ary Barroso. Mas há outros pontos de convergência: Fernando Sabino foi baterista de jazz. Sérgio Porto escrevia sobre música e compôs o "Samba do criolo doido". E até Rubem Braga deixou pistas de uma breve aventura pelo mundo da música: notas de imprensa mencionam uma parceria com Wilson Bastista, chamada "Todas elas me amam". Outra nota, de Aracy de Almeida em O Semanário, registra uma toada de Bororó com letra de Braga: "Canoa que vai pelo rio e lagoa/ Canoa que vai pelo mar/ Me leva, canoa, no teu rumo à toa/ Canoa que não vai voltar".
} 


\section{A NOITE É GRANDE: NASCIMENTO DO CRONISTA}

Depois de um breve período sem publicar em O Jornal, Maria retoma sua coluna em fevereiro de 1952 e rebatiza o espaço de "A noite é grande". É o início da construção pública de seu nome vinculado à noite carioca, aludida desde o título. De fato, em pouco tempo se tornaria um dos mais populares personagens da vida boêmia e artística do Rio de Janeiro.

"A noite é grande" é a única coluna com nome próprio na seção "Artes e espetáculos". A mudança denota um desejo de se estabelecer como cronista, como uma flor de poética própria que furasse aquele asfalto de notas chapadas. É um passo concreto em direção ao ofício. Também demarca a superação do rádio como assunto único e limitador, já que a coluna estava desobrigada de comentar programações radiofônicas.

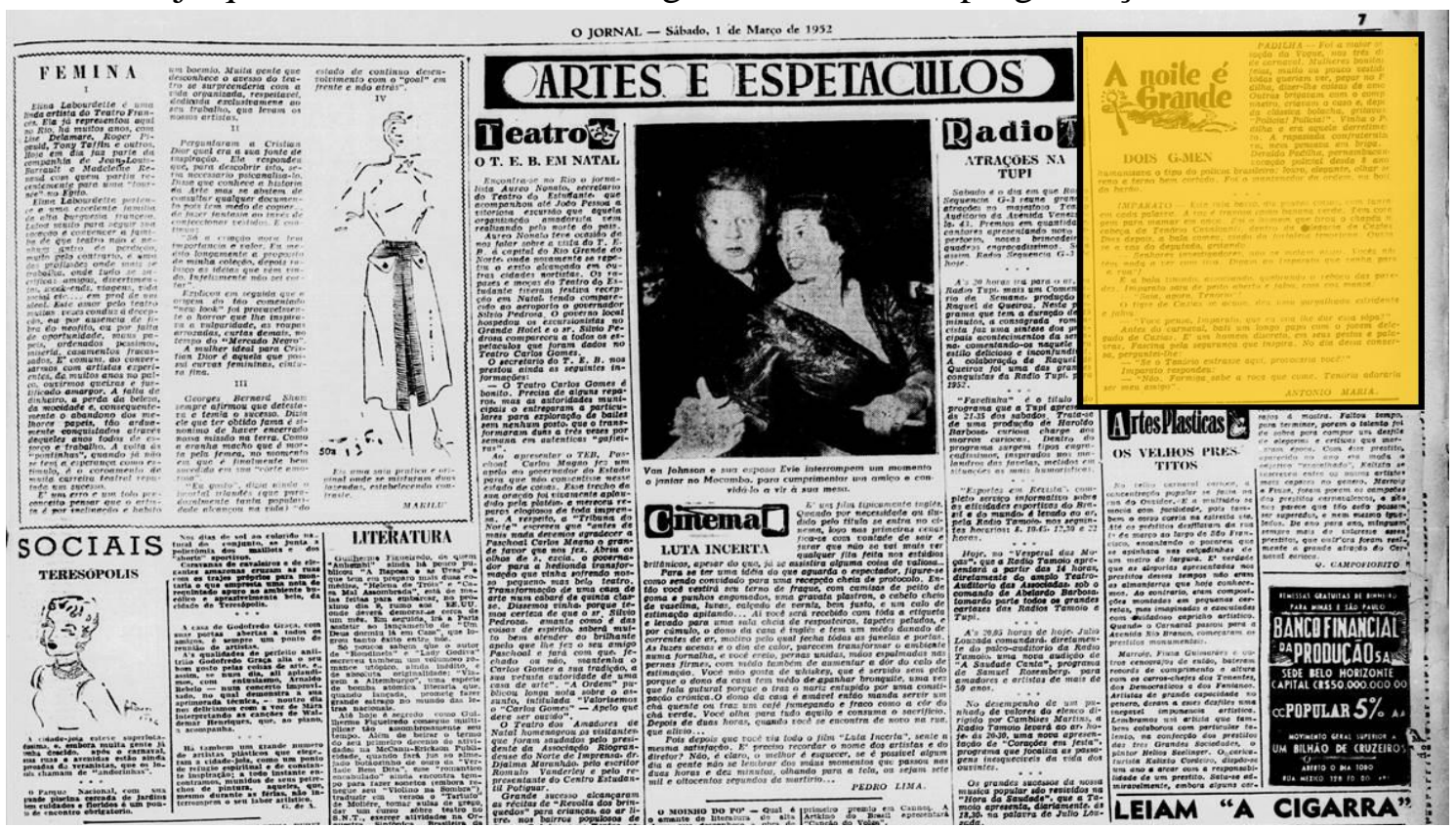

Ter uma coluna era parte fundamental da estratégia de Antônio Maria para mediar sua relação com o mundo. A partir de "A noite é grande", raros foram os períodos em que ficou sem um espaço autônomo nos jornais. E mais raros ainda, contraditoriamente, os momentos em que conseguiu cumprir o cronograma de entrega das crônicas. Quase todas as suas experiências de cronista foram marcadas pela irregularidade, provavelmente por conta do ritmo frenético de trabalho. E a frequência é um ponto determinante para que o cronista estabeleça e desenvolva um vínculo com seus leitores.

Em maio de 1952, após passar um mês sem publicar em O Jornal, Maria reaparece como colaborador da Última Hora, vespertino recém-fundado por Samuel Wainer. A falta 
de regularidade do cronista não parece ter afetado sua carreira inicial. Pelo contrário, o anúncio de seu nome entre os colaboradores transferia, de algum modo, seu prestígio ao novo veículo. O alto risco de sucessivas apostas só encontra justificativa no reconhecimento de seu talento por parte dos patrões. Responsável pela coluna " $\mathrm{E}$ passamos a apresentar!", Antônio Maria dá sequência ao que já vinha fazendo, inclusive em relação ao recorte temático. O texto de estreia, de 15/5/1952, faz um mea-culpa:

Tinha jurado aos meus santos prediletos, especialmente a Santo Antônio Maria Zacharias, barnabita e leão de chácara da minha alma, que nunca mais escreveria sobre rádio [...]. Depois de alguma resistência, capitulei, pelo telefone, e aqui estou, absolutamente certo de que irei criar uma porção de casos embora não sejam esses os desejos de um cidadão gordo e pacato, que ama "a próxima” como a si mesmo.

Fundado em junho de 1951, o jornal é considerado um marco da modernidade: sua disposição gráfica arrojada estabeleceu um novo padrão de qualidade. Valia-se de cores, charges, ilustrações, fotos enormes. Apostou numa política de valorização da coluna, pagando salários acima da média, escalando nomes já consagrados como Nelson Rodrigues e jovens promessas como Sérgio Porto. A estrutura era apadrinhada por um influente amigo de Wainer: Getúlio Vargas. Na tentativa de voltar à presidência da República, assegurou recursos de bancos públicos e privados para a iniciativa. Em pouco tempo, com sedes em São Paulo e no Rio de Janeiro, o jornal se tornou um dos mais vendidos do país. ${ }^{21}$

Nessa época, vivendo no Jardim Botânico com a família, Maria se aproximava dos temas e características que marcariam sua literatura por toda a vida. Tinha se afastado definitivamente dos bastidores do rádio, e já não participava da cena esportiva da Rádio Tupi desde que narrou, em pleno Maracanã, a amarga derrota do Brasil contra o Uruguai na Copa de 1950. Mais alinhado a vocações artísticas, crônicas curtas já eram frequentes. “O piano", de 11/6/1952, é um exemplo dessa primeira tomada de consciência:

Chovia na minha rua e tocavam-se valsas de Chopin. A casa do lado, de D. Marocas Filgueira, tinha dois meninos e duas meninas, todos dentuços, que sabiam de cor o adágio da "Sonata ao luar", de Beethoven. Apesar da chuva, eu ia espiar, por uma fresta na janela, o

\footnotetext{
${ }^{21}$ Sobre a influência de Getúlio Vargas no jornal, conferir ABREU, Alzira Alves de. A imprensa em transição: o jornalismo brasileiro nos anos 50. Rio de Janeiro: FGV, 1996.
} 
jeito daqueles meninos magros, espetados na ponta do cóccix, meio debruçados nas estantes, dando gosto e esperanças à família pacata da rua da União - em algum tempo, rua Rodolfo Araújo, em homenagem ao meu avô - musicando a tarde chuvosa. E me deu aquela vontade enorme de tocar piano. Falei em casa, contrataram Dona Arlinda Rocha e comecei a aprender. Meus dedos eram duros e exercícios não me falavam ao coração. Odiei o primeiro dia da "Marcha turca", de Mozart. Fui largando, largando, até crescer sem tocar Chopin. É o mal que mais me dói. Das coisas que queria ter sido e que não fui, pianista é a que mais lamento. É por isso que, hoje, ao jovem e pálido repórter que nos vem entrevistar, respondo todo malfeliz: "Eu escrevo programas porque não consegui tocar Chopin". Queria tocar aquelas valsas que ficaram na rua chuvosa, nas paredes dos sobrados molhados, nos dedos dos meninos dentuços que, provavelmente, já morreram de tísica.

A reformulação de uma tarde chuvosa do passado sugere uma lembrança em sépia que o cronista carrega como frustração. Passagens como "meus dedos eram duros" e "exercícios não me falavam ao coração" demarcam barreiras que o jovem Maria não conseguiu superar. Apesar do humor e da leveza, a sensação de incompletude e desconforto está sempre visível, seja em relação ao próprio corpo, à cidade ou às mulheres. As frustrações, por vezes, são retomadas em um processo contraditório de desnudamento elogioso. $\mathrm{O}$ reavivamento das misérias do passado é uma estratégia de construção da crônica de Maria. O cronista parece diminuir o que foi para aumentar o que é. Nesse sentido, a presença de um jovem repórter a entrevistá-lo é mais do que aparenta: é um gancho para o autoelogio, um símbolo de vitória, como se desse por vencida toda a peleja pela conquista do Rio de Janeiro. Agora era alguém - alguém por quem os outros podiam se interessar.

Apesar da expectativa e da crescente qualidade da prosa, a coluna na Última Hora dura menos de dois meses. O crítico que procurar entender o motivo pelo qual Maria deixou passar a oportunidade de se firmar como cronista estará confrontando suposições. O mais provável é que tenha optado por privilegiar o trabalho no rádio e na televisão, meios com os quais já tinha intimidade e a garantia de um bom trânsito social. Mas é impossível não pensar em suas inseguranças como escritor. Em O Jornal, compartilhava espaço com notas objetivas e aleatórias. Na Última Hora, porém, assinava uma coluna própria ao lado de nomes fortes, o que pode ter contribuído para seu acuamento. 
Seja como for, é provável que trilhasse um caminho protegido como cronista de destaque se tivesse permanecido no jornal de Samuel Wainer. Mais uma vez, porém, Maria abdicou dos trajetos seguros. E poucos dias depois de deixar a Última Hora, colabora com A Noite Ilustrada, revista semanal que circulava desde 1930 no grupo editorial de Irineu Marinho, pai de Roberto Marinho. Dessa vez, não assina coluna: publica duas crônicas avulsas em uma página rotativa, sem autoria fixa, onde circulavam variados tipos de pena: de escritores como Lúcio Cardoso, Celestino Silveira e Bastos Portela a figuras de poder como o general João Alberto Lins de Barros, interventor do estado de São Paulo nomeado por Vargas.

A colaboração episódica indica que Maria ainda pretendia se dedicar ao ofício da crônica, por mais contraditório que isso pudesse ser naquele momento. "Pensa, Pedro", inédita em livro, traz a recorrente experiência deslocada do cronista:

Eu te escrevo para pedir que não venhas, Pedro. Vai ser bonito, se chegares num dia claro, de céu azul, de praia cheia de gente. Será um deslumbramento a moça saindo do mar - com um maiô tão pouco e o busto tão muito - e se deitar na areia, a rir das tuas ombreiras e das bocas das tuas calças. Sentirás o que eu senti, há doze anos, e escreverás a todos os teus amigos. Mas é melhor que não venhas. Será uma alegria apertar a mão da estrela do rádio, pensar uma coisa bem agradável, dizer e perder o fôlego. À noite, irás fazer a ronda dos bares de Copacabana, conhecerás os poetas, cronistas e pintores. Verás a moça do cinema, uma outra do teatro, verás gente de livro e de jornal. Dirás: será mesmo aquele o Rubem Braga? E o Braga te dirá uma frase bem curta, para que tu não entendas e ainda te sintas feliz. De que te servirá a apresentação ao poeta Bandeira se, com toda certeza, ele não vai gostar dos teus versos? Para que o tempo e a emoção de entregar os originais do teu livro de contos ao escritor Álvaro Lins, na esperança de uma edição José Olímpio?

Depois, quando passar o ineditismo, quando vires a rua e as gentes, os automóveis e a polícia - tudo sofrendo, Pedro - vais sentir saudade da tua rede, do jardim da tua casa e saudade de ti, quando eras puro. Não troques o ensopadinho da tua casa, a conversa da família em volta de ti, as horas certas de almoço e jantar, pelo restaurante francês que te obrigará a comer sempre o que não pretendias, sozinho numa mesa ou 
ao lado de uma mulher que não te quer muito. Não deixes o teu quarto - com o teu guarda-roupa, tua estante de livros e aquela cadeira onde há sempre um paletó - pelo cômodo ruim que vais ter em Copacabana. Não te deixes deslumbrar pela palavra "apartamento" como eu me deslumbrei, há doze anos, a ponto de esquecer a palavra "sobrado". Hoje, eu queria tanto voltar ao sobrado e não posso. Todo mundo vai dizer que eu fugi e todos estão de olho em mim. Vim andando ao longo da praia, vim deixando, na areia, as marcas das minhas botinas e todos me seguem, e todos me descobrirão, e todos sairão correndo e gritando, se eu tentar escapar: pega o ladrão! Pega o ladrão!

Fica, Pedro. Tua cidade é tão linda. Se o que te inquieta é o sossego, agita-te dentro de ti mesmo. Depois, em volta de ti. Cria um caso, rouba a mulher do outro, foge para o mato e, quando voltares, sorri para quem te ameaçou de morte. De noite, vai à boite, pede uma "bebida fechada", acende o teu cigarro e todos te olharão empolgados. Faze de ti um ídolo daí e não ouvirás o chamado do navio, que some no fim do mar, nem o voo do avião, te chamando todo dia.

Fomos uns dez e viemos na mesma leva, Pedro. Acreditamos em páginas de revistas, telegramas de jornais e notícias de rádio. Fomos na conversa dos que vinham passar tempo e voltavam contando coisas, falando sem esta sinceridade com que te digo, agora, verdades tão cruas. É verdade que experimentamos uma porção de alegrias, que nos deslumbramos centenas de vezes. Mas, agora? Tudo o que acontece é reprise, com os mesmos personagens, o cenário mesmo, causando-nos a mesma saciedade que te causa, aí, a repetição do teu dia.

Arranja um jeito, faze uma força e fica, Pedro. Não venhas pela moça de maiô, pela boite que acaba de manhã, nem pela vontade de vencer na vida. Vida não é páreo e, se é, ninguém vence. Esbaforidos, imprestáveis, chegamos todos empatados. Se vieres e se um dia pensares que venceste, vais ver que ganhas muito e vives pouco. Tentarás voltar, mas, atrás de ti denunciando, estarão as marcas dos teus pés, na areia da praia, e haverá um bandão de gente louca para gritar: pega o ladrão! Pega o ladrão!

Pensa, Pedro: valerá a pena? 
O conselho ao amigo que pretende desbravar o Rio também poderia ser um solilóquio de Maria com seu passado. O Maria de metade de 1952 estava bem encaminhado, com bom emprego na rádio e na TV Tupi, inaugurada há pouco mais de um ano. ${ }^{22}$ Tudo que almejara em sua primeira empreitada pela capital. Aquele jovem que se deslumbrou com "a moça saindo do mar", com os "poetas, cronistas e pintores", com Rubem Braga e Manuel Bandeira, agora sabia que a forte recusa ao pernambucano iniciante era uma resposta quase natural do establishment carioca.

A cidade o repelira em muitas instâncias, do deboche da moça ao cardápio imposto do restaurante. A consciência do descompasso ligado à origem nordestina torna a estruturar sua crônica em torno das dificuldades sentidas, graves a ponto de ser tomado por ladrão. Forma-se um imaginário ressentido, no qual figuram até mesmo os líricos, universo em que o cronista se acha incapaz de penetrar: Rubem Braga lhe diz algo inacessível, e Manuel Bandeira não gosta dos seus versos.

Num movimento que lhe é muito peculiar, Maria elenca todas as dificuldades sofridas na juventude como modo de redimensionar o valor de tê-las superado. Agora, o imigrante maduro é capaz de aconselhar o mais jovem, pois tendo se acidentado na tentativa de tomar o atalho, precisou fazer a curva longa do aprendizado. E apesar de ter vencido em termos práticos, isto é, financeira e profissionalmente, convive com um travo de amargor, como se estivessem pendentes muitas realizações pessoais: "Se vieres e se um dia pensares que venceste, vais ver que ganhas muito e vives pouco. Tentarás voltar, mas, atrás de ti denunciando, estarão as marcas dos teus pés, na areia da praia, e haverá um bandão de gente louca para gritar: pega o ladrão!". É impossível ler "Pensa, Pedro" sem lembrar de "A senha do sotaque".

A segunda crônica publicada no suplemento A noite ilustrada é "Summer jacket". Embora mais breve, evoca a mesma sensação de intenso desconforto. Dotada de um humor gauche, desvela como determinadas situações sociais podem camuflar preconceitos com extremo requinte. Numa festa de gala, por não vestir smoking, Maria é tomado por garçom: "Estávamos em pleno inverno e eu só tinha uma summer jacket, que foi feita às vésperas da última festa inaugural da Tupi”. Deslocado, o cronista tenta sem

\footnotetext{
${ }^{22}$ A TV Tupi, primeira emissora da América Latina, foi fundada em São Paulo em setembro de 1950. A inauguração foi solene e contou com Lolita Rodrigues entoando o "Hino da televisão", de autoria do poeta Guilherme de Almeida e do músico Marcelo Tupinambá. A TV Tupi do Rio de Janeiro foi inaugurada em janeiro de 1951. Lá, Antônio Maria foi diretor de programação.
} 
sucesso se diferenciar dos serventes, que trajavam, justamente, summer jackets. Quando se deu conta, já estava recebendo pedidos de uísque dos senadores: "Sofria tanto aquele apoucamento, horas de lentos minutos, sem um pensamento ou lembrança na cabeça, gosto de passa velha na boca, suor na testa”. Descobre que mesmo frequentando eventos da alta sociedade, não há fiança de pertencimento. ${ }^{23}$

É sintomático que Maria escreva sobre agruras pessoais em um momento de grande realização profissional. De um lado, expor dificuldades por trás das conquistas que gosta de exaltar parece ser sua mediação possível com o mundo. De outro, há fatores sociais que contribuíram para esse deslocamento. A origem nordestina é com frequência motivo de ataques e descrições maledicentes de colegas. Além disso, a ascendência negra de Maria é ainda um assunto a ser desenvolvido - todas as descrições que focam aspectos físicos negativos apresentam a palavra "mulato". Embora a questão racial não apareça em primeiro plano em sua obra, os traços da negritude certamente compõem o quadro de dificuldades que enfrentou no Rio de Janeiro. Em suas memórias, Jô Soares relembra um episódio em que o apresentador Flávio Cavalcanti atacou Maria em seu programa de televisão, chamando-o de mulato. "Claro que eu sou mulato. Como 99\% da população. Mulato não é insulto, é constatação", (SOARES, 2017, p. 207), teria respondido o cronista. Em 1957, Maria aparece num capítulo de Introdução crítica à sociologia brasileira, de Alberto Guerreiro Ramos, em que o sociólogo analisa personalidades negras e mestiças que reproduzem racismo. ${ }^{24}$

Talvez por não se sentir realizado em nada, Maria era onipresente em todas as frentes: rádio, televisão, jornal e boates, com as quais colaborava com textos de apresentações para as programações musicais. Ambientes e ritmos pouco propícios para aflorar a literatura. Uma das peculiaridades da crônica da década de 1950, no entanto, era justamente a demanda pelo convívio social, pelos encontros, pelos grupos. Esse trânsito

\footnotetext{
${ }^{23}$ Maria sempre viveu um desregramento financeiro, ainda que ganhasse altos salários. Interessava-se mais em estar presente nas rodas do que em construir algo para si. Ocupar um cargo de influência no ramo artístico seria, assim, mais um modo de se conectar às coisas do que de enriquecer. Seus trajes eram grosseiros, como descreve Ruy Castro: "Maria era mulato claro, tinha cabelo ralo e aderente ao coco, suava muito, amarrava as calças com barbante e usava sandálias de couro. Só tinha um terno. Essa descrição não se aplicava ao seu tempo de vacas magras, mas ao atual, em que era o homem mais influente da Rádio Tupi” (2015, p. 151). Embora Maria apareça bem trajado em fotos do período, essa visão grosseira e um tanto caricata de seu estilo foi a que prevaleceu nos trabalhos biográficos.

${ }^{24}$ Guerreiro Ramos refere-se à coluna "Mesa de pista", do jornal $O$ Globo, de 18/1/1955, em que Maria escreveu numa legenda: "Esta é a bonita bailarina negra Nilza, do elenco do Béguin. Bela de corpo e de cara. Dela se poderia dizer: "isso em branco..."”.
} 
entre mesas e lugares foi o que permitiu Maria ingressar pouco a pouco com o universo da crônica.

O carimbo do reconhecimento literário veio somente em agosto de 1952, quando passa a integrar o jornal Comício, fundado por Rubem Braga, Joel Silveira e Rafael Corrêa de Oliveira. O semanário teve vida breve, mas suficiente para marcar época. Circulou entre maio e outubro de 1952. Entre seus colaboradores, estavam Fernando Sabino, Otto Lara Resende, Lúcio Rangel, Paulo Mendes Campos, Carlos Castello Branco, Sérgio Porto, Millôr Fernandes e Clarice Lispector, que assinava a sessão feminina com o pseudônimo de Tereza Quadros. A despeito do caráter explicitamente antigetulista, Comício era rodado nas oficinas do jornal Última Hora, de Samuel Wainer, apoiador de Vargas. Nas palavras de Sabino, não se tratava de uma revista,

mas também não era um jornal: era um semanário independente, como se apresentava na capa, em duas cores. [...] Não era humorístico, pelo menos na intenção - o que se pode deduzir pela seriedade do título -, mas era alegre, descontraído, desabusado. (1999, p. 126)

A inusitada combinação entre política de esquerda e descontração geral da redação foi, de fato, uma marca do semanário. O projeto editorial era capaz de diagramar o artigo "Só a classe operária poderá liquidar o socialismo" ao lado das palavras-cruzadas. Charges e ilustrações de Millôr reforçavam um posicionamento aberto às coisas leves, criando um terreno propício para a crônica. Dos escritores escalados, todos praticaram o gênero. Havia uma convivência natural entre jornalismo e literatura. Os escritores não apenas publicavam nos jornais, mas participavam da vida da imprensa.

Rubem Braga era responsável por uma crônica em formato de carta, com destinatários variados - a uma senhora, a um general, ao presidente. No número dezesseis, Maria assume um espaço, batizado novamente de "A noite é grande", e publica uma crônica com o fluxo epistolar invertido. "Carta de mãe", inédita em livro, marca sua estreia em 29/8/1952:

Quando nascestes, eras tão volumoso que a parteira te trouxe, após o banho, ergueu-te à altura do seio materno, dizendo-me isto:

- Toma-o: bota vinte litros! 
Nessa noite, crianças morreram de difteria, mulheres deram à luz três filhos mortos e ninguém nasceu vivo - só tu. Na manhã seguinte, choveu muito e o homem do cuscuz não passou.

Como vês, és um pouco diferente dos outros e tens que tomar uma porção de cuidados pelos caminhos da vida. Tua primeira babá pôs pimenta em teus olhos e tentou quebrar tua moleira com um bilro de fazer renda. A segunda, a que se chamava Florinda, aproveitando um momento em que não havia ninguém por perto, deu-te um conhaque Macieira para beber. Aos dois meses, tiveste que usar óculos escuros por causa de uma irritação causada pela pimenta. Custaste muito a falar a tua primeira palavra: foi "feijão". Quando saíste de casa, levaste muita bênção e pouco dinheiro - mesmo porque, se escolhesses pouca bênção e muito dinheiro, ias me deixar em falta. Mas deves estar lembrado do quanto choramos abraçados e quantas vezes te recomendei um milhão de cuidados. Pedi que não dormisses sem a tua touca, que não bebesses água fria depois do café, e que não te metesses com mulheres cheirosas de olhos pidões.

Hoje, é a quinta vez que te escrevo, para pedir que não te metas a cronista de jornal. Cinco cartas te mandei e cinco vezes não deste a mínima importância aos cuidados de tua mãe. De que te serve o jornal? Tu começas a escrever, dizem que és muito engraçado e, depois, não sei por que, o dono do jornal te despede. Tu não sofres, porque és mesmo um caráter grosso, mas te abismas em pensar como depois de receberes tantas felicitações dispensam tua colaboração.

Faze o que sempre te pedi. Fica em teu rádio.

Se sabes fazer programas musicais, se inventas histórias e ganhas o de que viver, por que ainda te metes em jornal? Aqui, cobrindo-te de bênçãos e rezando a Deus pelos teus minutos,

\section{É A TUA}

A figura da mãe ressurge como cuidadora. Zela pela proteção do filho vulnerável - "um pouco diferente dos outros", necessitando "tomar uma porção de cuidados pelos caminhos da vida" - e pede que ele se proteja do jornal. A experiência pessoal, desde o nascimento marcada por glórias e fracassos, imprime uma espécie de sina em Maria, como se estivesse fadado a ser um vitorioso desgraçado, ou vice-versa. A figura materna 
ressignifica o ofício de cronista, que toma proporções quase trágicas. Mais uma vez, como forma de autovalorização, Maria aponta os riscos de algo que começava a fazer. As intenções não deixam dúvida: a crônica é algo que Maria almeja. Por isso, Comício representa um marco inicial em sua carreira de cronista. Sob o disfarce de desafiar o vaticínio materno, tematiza todas as tentativas anteriores: "É a quinta vez que te escrevo, para pedir que não te metas a cronista de jornal”. Pela primeira vez, para além da intenção, há prática regular, suporte físico, maturidade do texto e reconhecimento de seus pares.

\section{MENINO GRANDE: MÚSICA E SAMBA-CANÇÃO}

Uma das primeiras aquisições de Maria quando se firmou profissionalmente foi um Cadillac. ${ }^{25}$ Símbolo máximo da ostentação, o conversível preto tinha um papel importante naquele estilo de vida desgarrado - transportava o cronista de boate em boate e ainda lhe servia de escritório, como conta seu biógrafo:

Maria começou a década casado com Maria Gonçalves, a Mariinha, mãe de seus dois filhos, na rua Nina Ribeiro, no Jardim Botânico. Mas, até que aqueles anos dourados terminassem, morou ainda com a atriz Yolanda Cardoso, na rua Gomes Carneiro, $\mathrm{n}^{\circ}$ 7, em Ipanema, e com a secretária Ligia Andrade, na avenida Delfim Moreira, no Leblon. Brigou muito com todas elas e a toda hora saía de uma casa para outra. [...] Morou no Hotel Plaza, na Princesa Isabel, na Gávea e também na Sernambetiba, mas dormia eventualmente na casa de amigos ou namoradas. Para que sua produção jornalística não falhasse nunca, carregava dentro do tal Cadillac uma máquina de escrever. Chegou a redigir algumas crônicas ali dentro mesmo, no meio da rua. [...] Maria passou Copacabana a limpo, mas de Cadillac. Também era, ao seu estilo, um outsider, mas um marginal charmoso, apesar do desleixo visual, e louco para ser aceito pelo grande monde. Copacabana era sua aldeia, o laboratório de onde analisava o comportamento do planeta. Frequentava da boate Vogue, do barão Stuckart, ao restaurante Cabeça-

\footnotetext{
${ }^{25}$ Paulo Mendes Campos, em perfil publicado na Manchete: "Antônio Maria era um gordo, mas um gordo que tinha a inesperada agilidade dos elefantes, a mental e a física. Sempre disse com muito orgulho que só sabia fazer bem uma coisa: dirigir automóvel. De fato dirigia magnificamente bem seu vasto Cadillac, com muita cadência e segurança. Uma vez, no antigo Vogue, em plena madrugada boêmia, foi um custo dissuadi-lo a desistir de disputar uma corrida do Rio a Petrópolis com Fernando Chateaubriand. Ninguém segurava Antônio Maria, a não ser o senso humorístico, e foi para este setor que tive de apelar. O automóvel lhe dava uma mobilidade surpreendente, uma espécie de ubiquidade que todos aceitavam; ninguém se espantava de vê-lo no Sacha's e, poucas horas depois, de sabê-lo ainda pegando um fim de noite numa boate de São Paulo" (1974, p. 39).
} 
Chata, do idem Manezinho Araújo. Nada que era Copacabana the era indiferente. (SANTOS, 2006, p. 64)

Como se vê, sua vida era bastante movimentada. Mesmo ganhando bem, não conseguia equilibrar a balança sentimental e financeira. Gastava demais, envolvia-se em brigas nas boates e tinha casos extraconjugais de conhecimento público, como a maioria dos homens de seu grupo. Maria parecia insaciável. Animado com a experiência positiva de Comício e embalado pelos bons ventos de 1952, transfere as energias para outro campo artístico: a música popular. Como compositor, conseguiu reunir diversas esferas de sua vida profissional, circulando com desenvoltura ao passar das páginas de rádio para as colunas de música, da ronda noturna pelas boates até as crônicas nos jornais.

Nora Ney, uma das cantoras próximas de Maria, foi a primeira a gravar suas músicas no Rio. ${ }^{26} \mathrm{Na}$ Rádio Tupi, onde trabalhavam, Maria descansava numa sala arranhando notas no violão. A cantora se interessou por uma de suas músicas e prometeu gravá-la, se tivesse oportunidade. Em maio, Nora Ney lança pela Continental seu primeiro compacto em 78 rotações. De um lado, "Quanto tempo faz", de Paulo Soledade e Fernando Lobo. Do outro, "Menino grande", de Antônio Maria.

"Menino grande", que passou a ser um dos epítetos do autor, é uma composição em que se notam estratégias similares às de suas crônicas - a mesma experiência pessoal desnudada, tensionada entre a exposição de um fracasso e a valorização de uma conquista. Naquele Rio de Janeiro tão embalado pelo samba-canção, o sucesso foi estrondoso.

Eu gosto tanto do carinho que ele me faz

Faz tanto bem o beijo que ele me traz

As horas passam, ligeiras, felizes

Sem a gente sentir

Ele está ao meu lado, com o corpo cansado

Precisa dormir

Dorme, menino grande

Que eu estou perto de ti

Sonha o que bem quiseres

Que eu não sairei daqui

26 "Frevo n ${ }^{\circ}$ ", composta quando ainda morava no Recife, foi gravada por lá pelo Trio de Ouro, em 1951, com o título de "Recife". 
O trecho destacado idealiza, como em tantas outras canções, um tipo de mulher companheira e complacente, que acolhe o homem cansado. Mas difere delas num ponto central: o movimento de carinho parte do homem. Retratada sempre como fonte de afeto, aqui a mulher é quem recebe o beijo. Essa inversão do fluxo usual aponta uma das sutilezas de Maria em relação ao amor. Num contraponto musical, a virilidade cede espaço a alguém terno, atento, capaz de prover delicadezas. Essa imagem do homem afetuoso e vulnerável se conecta a um desejo íntimo, diferencial que o compositor parece oferecer e conhecer bem.

Em seguida, a mesma voz sugere, em tom maternal, que vai proteger o sono do amado, ecoando a mãe da crônica de Comício: "Pedi que não dormisses sem a tua touca, que não bebesses água fria depois do café, e que não te metesses com mulheres cheirosas de olhos pidões". Maria entregava o coração numa bandeja. É interessante notar como o samba-canção, por uma questão de afinidade temática, é um gênero que acolhe essa exposição melhor do que a crônica.

O acalanto "Menino grande" conquistou diversos admiradores. Entre eles, Getúlio Vargas, que sempre o solicitava em apresentações e por quem Nora Ney, militante comunista, não tinha nenhum apreço. ${ }^{27}$ Com o sucesso comercial do disco, Nora Ney foi convidada pela gravadora a repetir a empreitada. Em novembro de 1952, um segundo compacto foi lançado, novamente com uma composição de Maria: "Ninguém me ama", o samba-canção que coroaria em definitivo ambas as carreiras.

O compacto rendeu o primeiro Disco de Ouro da história da fonografia brasileira. A composição virou o hino da fossa, solicitado em todas as boates, executado em todas as rádios. Mário Lago disse que "Maria tinha inventado o 'samba de mão no ombro' em que o cantor parece pedir uma palavra amiga" (CASTRO, 2015, p. 152) - construção de intimidade muito similar às artimanhas da crônica. Embora a canção seja creditada em

\footnotetext{
27 Anos mais tarde, Nora Ney foi exonerada da Rádio Nacional por perseguição política. Por decreto publicado no Diário Oficial, o marechal Castello Branco demitiu 67 funcionários da rádio. A lista, com nomes como Oduvaldo Vianna, Dias Gomes, Mário Lago, Heitor dos Prazeres, Nora Ney e Jorge Goulart, seu companheiro, foi formulada pelos interventores com ajuda de três colegas de trabalho. A demissão em massa foi uma retaliação ao fato de a rádio ter aberto seus microfones para discursos em defesa da democracia no dia em que o golpe civil-militar se instalou. Entre os oradores, estava o deputado federal Rubens Paiva, torturado e assassinado pelos militares em 1971. Para mais informações sobre o fato, conferir LAGO, Mário. Bagaço de beira-estrada. Rio de Janeiro: José Olympio, 2012.
} 
parceria com Fernando Lobo, sabe-se que a letra é toda de Maria, e que a inclusão do amigo era uma camaradagem comum entre os dois. ${ }^{28}$

Com o Disco de Ouro, "Ninguém me ama" chamou a atenção do mercado internacional, foi gravada por Nat King Cole e chegou ao cinema, no filme Carnaval Atlântida, do mesmo ano. O sucesso da canção parece estar no desnudamento completo das sensações, sem nenhum pudor, um movimento de grande simplicidade que vinha sendo aperfeiçoado desde suas primeiras crônicas:

Ninguém me ama, ninguém me quer

Ninguém me chama de meu amor

A vida passa, e eu sem ninguém

E quem me abraça não me quer bem

Vim pela noite tão longa de fracasso em fracasso

E hoje descrente de tudo me resta o cansaço

Cansaço da vida, cansaço de mim

Velhice chegando e eu chegando ao fim

O gênero samba-canção, marcado pela evocação do sofrimento e da desilusão amorosa, ditava o ritmo das noites cariocas, envolvidas por uma espécie de névoa existencialista e fumaça sofisticada das boates. Nesse cenário, a crônica, gênero com inclinações à vida urbana e à reorganização das coisas pequenas do dia, também se deixa envolver pela névoa.

\section{PERNOITE: O CRONISTA NOTURNO}

Antônio Maria foi o grande cronista da noite. Talvez o único a compreender que escrever sobre a noite não é negar o dia, mas se enfronhar num novo estilo de vida naquela estrutura social. Para o cronista noturno, a dimensão do trabalho não está descolada do prazer. Maria frequenta as boates a trabalho. E assim como um médico ressignifica a experiência da morte, o cronista da noite desenvolve uma relação peculiar com a dinâmica das relações noturnas.

Todos os infortúnios se acumulam e se liquidam nos balcões de bar, o "tristonho sindicato de sócios da mesma dor”. A noite pede o ombro amigo, o conselho. Pede a união

\footnotetext{
${ }^{28}$ No sentido contrário, "Preconceito", creditada em parceria com Antônio Maria, é só de Fernando Lobo.
} 
das pessoas em torno da mesa, a cantoria. A noite abriga os solitários e proporciona remédio. É a hora dos viciados, dos decadentes, das comemorações. Traz a simbologia dos amigos e o esbarrão com os desafetos. Dos encontros carnais e das separações violentas. A paz do silêncio da madrugada e o disparo da arma, o frasco de veneno, o suicídio. Sentimentos e emoções difusos, mesmo opostos, mas que misturados dão o tom e o ritmo a uma atmosfera quase que suspensa no tempo, mantida essencialmente por uma classe abastada em ambientes internos, escuros e fechados.

Maria era um artista em ascensão em uma nova lógica social, consolidando-se com velocidade em todas as áreas em que atuava. Como cronista, já tinha o reconhecimento de seus pares e espaço em veículos de destaque. Na música, era compositor de sucessos. E como comunicador, apresentava e colaborava com programas famosos. No final do ano, novamente na esteira da atuação política de Getúlio Vargas, dá outro salto profissional. Em troca de apoio, Vargas injeta recursos na rádio Mayrink Veiga $^{29}$ que, reestruturada, leva grandes nomes da Tupi:

Maria transferiu-se para lá com um contrato de 50 mil cruzeiros,,$^{30} \mathrm{o}$ mais alto salário do rádio no país. Levou para a nova emissora o [programa] "Rua da alegria", invertendo o nome para "Alegria da rua". Escreveu ainda "Teatro de comédia", "Levertimentos", "Cássio Muniz, o cronista do mundo" e "Regra três". Chegou a ter três programas por semana, num ritmo de produção de mais de treze laudas cada um. Além disso, compunha, escrevia as colunas dos jornais e os shows da boate Casablanca, e produzia jingles para diversos produtos. (SOUSA, 2010, p. 70)

Tudo isso deve ter colaborado para que Maria integrasse uma das primeiras escalações da revista Manchete. Em alta estima nas mesas das boates, Maria vive um de seus grandes momentos como escritor, publicando uma crônica semanal na mais prestigiosa revista da época. Essa é uma atuação que demonstra como os cronistas se beneficiavam dos trânsitos sociais e, em certa medida, dependiam deles. Sobre o período inicial da Manchete, que

\footnotetext{
${ }^{29}$ No período da Mayrink Veiga, Chico Anysio atuava em diversos programas humorísticos, os de Antônio Maria inclusive. Chico também era responsável pelo texto de cinco programas, e fala sobre sua maior referência em seu livro de memórias: "Quando comecei na Mayrink Veiga, era o texto de Antônio Maria que procurava imitar" (ANYSIO, 1992, p. 95).

${ }^{30}$ Segundo o decreto $\mathrm{n}^{\circ} 30.342$ de 1951, o salário mínimo em 1952 era de 1.200 cruzeiros. Os rendimentos de Maria no rádio representam, portanto, 41,6 salários mínimos. Não há informações sobre os valores de seus outros salários.
} 
ajudou a modernizar a imprensa com uso artístico de fotografias e uma linguagem mais rápida, Fernando Lobo registra:

A revista $O$ Cruzeiro pontificava como a melhor publicação no gênero. [...] Quando chegava o dia de circulação de $O$ Cruzeiro, era um correcorre nas bancas do Brasil. Era o que havia de melhor, jornalisticamente falando. Um belo dia surge na praça a revista Manchete, com ares de quem queria brigar com o gigante. Os primeiros números, dirigidos por Henrique Pongetti, foram melancólicos. Havia muita cor, muitas fotos e nada de miolo. Foi quando Adolfo Bloch pintou no nosso ninho [a mesa do bar Vilariño] em busca de munição. Foi uma revoada: Rubem Braga, Sérgio Porto, Lúcio Rangel, Darwin Brandão, Antônio Maria, Paulo Mendes Campos, Joel Silveira e Ibrahim Sued voaram para a rua Frei Caneca, onde ficava a redação da revista. [...] No leme do comando estava Hélio Fernandes, conhecedor profundo da cozinha de um jornal, mestre em fazer o tempero que o leitor aprecia. [...] Tudo caminhava magnificamente. A Manchete empinava o voo, enquanto $O$ Cruzeiro, em constantes mudanças de direção, ia perdendo seus melhores colaboradores. (1991, p. 16)

O Cruzeiro (1928-1975), de Assis Chateaubriand, foi a mais prestigiosa das revistas ilustradas durante muito tempo. Impressa em papel de qualidade superior, não é exagero dizer que impôs um novo código visual à imprensa. Praticamente criou a fotorreportagem, gênero em que texto e imagem compõem a reportagem em pé de igualdade.

Pelo frescor da novidade, o surgimento da Manchete (1952-2000) arrebatou o leitorado das revistas, de maior poder aquisitivo e composto em especial por mulheres. ${ }^{31}$ As revistas eram mais caras e, ao contrário do jornal, não tinham obrigação de informar. Livres para focar no entretenimento, estabeleceram uma outra relação com o tempo, valorizando reportagens mais longas, desdobramentos de matérias e dossiês temáticos, tudo munido de muita fotografia.

Nessa nova disposição editorial, a crônica desempenhou papel de destaque. De leitura fácil, o gênero foi bem acolhido pelas revistas. Ocupando geralmente uma página

\footnotetext{
${ }^{31}$ Os centros urbanos do Brasil já estavam acostumados com a linguagem de revistas. De perfis similares, várias tinham circulado anteriormente, como Vida Doméstica (1920-1962), Rio Magazine (1933-1964), Diretrizes (1938-1944), Sombra (1940-1960), Revista do Rádio (1948-1970) e O Mundo Ilustrado (19521957).
} 
inteira, era a medida exata da literatura para o entretenimento. Toda boa revista tinha seu time de cronistas - e a Manchete, além dos nomes citados por Fernando Lobo, contava ainda com Fernando Sabino e Henrique Pongetti.

Lá, Maria assina a coluna "Pernoite" do número 29 ao 86, de novembro de 1952 a dezembro do ano seguinte. Sobre um fundo cinza e ocupando metade da página na vertical, as crônicas do período representam a primeira experiência de Maria totalmente dedicada à literatura. $\mathrm{O}$ universo da ronda noturna, tão caro ao estilo do cronista e aludido desde o título da coluna, é explorado com maturidade em um vasto repertório de assuntos, digno do cronista moderno com uma paleta variada de cores: reflexões filosóficas, causos, vida urbana, observações generalizadas, relatos de viagem, comentários da semana, impressões vagas sobre amores e desilusões. ${ }^{32}$

32 "Pernoite" é a única coluna recolhida em livro, quase inteiramente, com exceção de quinze crônicas. Foi publicada sob título homônimo em 1989, em projeto da Funarte, vinculada ao Ministério da Cultura. José Aparecido de Oliveira, então Ministro da pasta, foi amigo de Antônio Maria, com quem chegou a dividir apartamento. 
Outros “cronistas noturnos", como Fernando Lobo, cuja coluna se chamava "Pelas esquinas da noite", também se enfronhavam pelo mesmo universo. Mas Maria foi o único capaz de superar a boate, isto é, de compreender a noite em sua amplidão, interessandose pelas ruas da cidade e pelas relações pessoais, dos affairs da alta sociedade aos pobres trabalhadores. Enquanto alguns colegas cronistas e repórteres tomavam a noite como ponto de partida ou chegada, Maria captava o todo: se educava na madrugada mas batia o ponto de manhã.

Por formular a dimensão noturna como poética em vez de assunto, Maria estava livre para levar sua crônica por outros caminhos. No período da Manchete, a memória é um pilar do conjunto. É como se Maria, numa segunda fase da vida, tivesse superado o momento anterior, a ponto de poder revisitá-lo à distância. Nesse sentido, o conjunto da Manchete ganha a força da experiência pessoal consolidada, na pena de um escritor à vontade. "As três fotografias", publicada em 31/1/1953, é uma das mais belas crônicas do período:

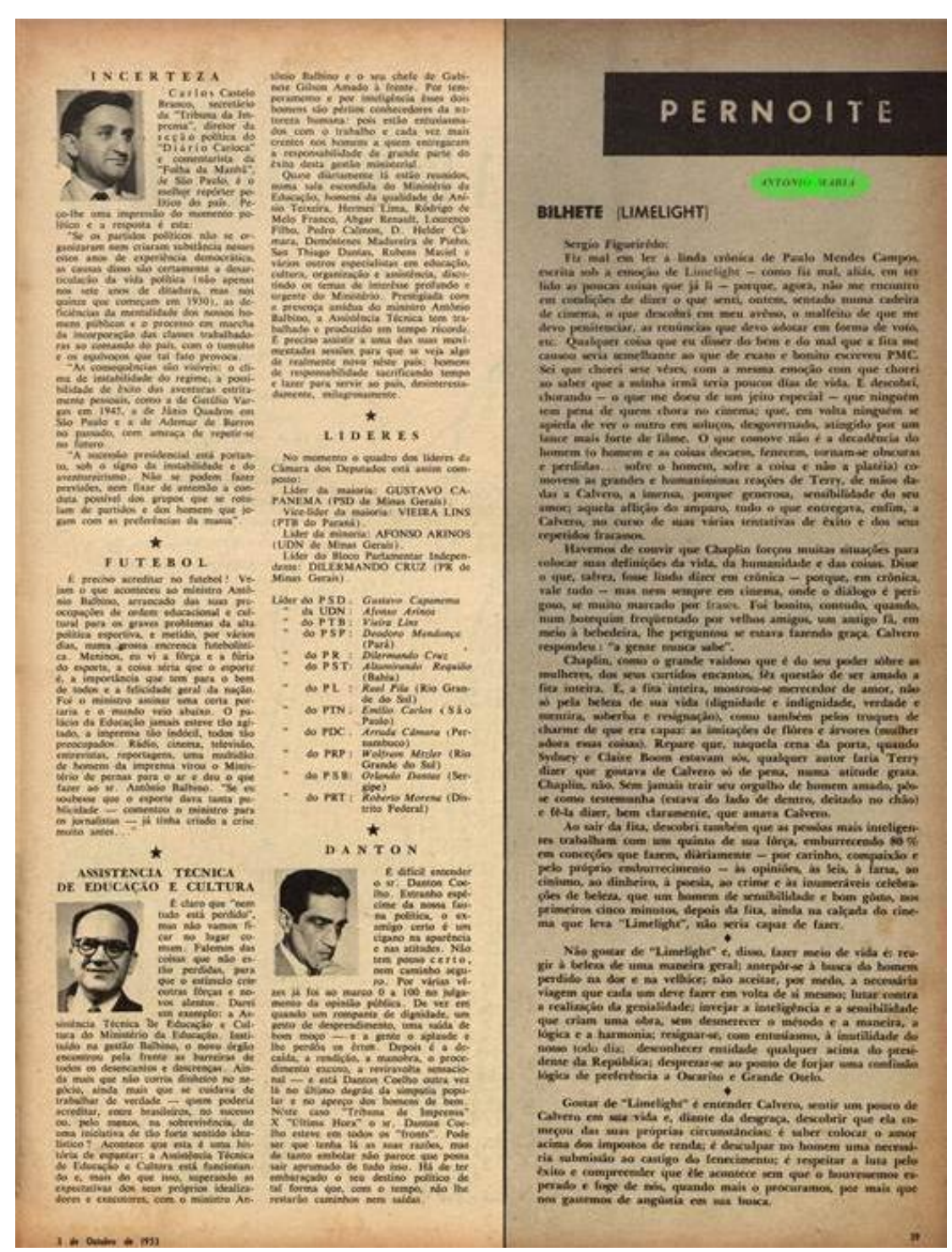

A gente assiste ao cigarro se gastando, ouve os carrilhões da vizinhança, vê a chegada das noites e não se apercebe de que tudo isso é o tempo, andando. Os espelhos são de uma discrição fabulosa e não nos contam nada, de manhã, quando lhes perguntamos as coisas. Mas, quem sabe de nós é o retrato $3 \times 4$ da carteira de identidade. Toma o teu, espia bastante para ele, amigo, e verás que horas são, nos teus cabelos, na preguiça dos teus olhos e no corte vincado da tua boca. 
Aqui estou eu, diante de mim, em três fotografias coladas nos documentos que me dão trânsito livre pela vida em fora: a carteira de identidade, a de chofer e o passaporte.

- Como vais tu, rapazola do Recife, em março de 1940? Eras um herói e vivias de muitas esperanças. Mandaste fazer uns ternos, uma porção de camisas e inventaste de comprar um chapéu. Depois, recebeste uma passagem do Almirante Jaceguai, uns abraços no tombadilho e muitos adeuses no cais. Um daqueles lenços era o da tua namorada, que, um mês depois, já nem se lembrava de ti. Mas, o mundo era generoso e te daria outra. À bordo fizeram uma roda de moças e contaste umas histórias inventadas, que alcançaram muito sucesso. Houve quem não acreditasse nos teus anos e mostraste a carteira de identidade. Acharam que tu eras um prodígio e, de lá para cá, até hoje, não fizeste outra coisa, senão inventar histórias para engabelar e conquistar os outros.

Agora, sabes dirigir automóvel, tens um bigode de carta de baralho (rei de espadas) e os teus olhos são penetrantes. Tua boca é de quem já provou beijos mais maduros. O que se vê do teu corpo - os ombros e o peito - é de gente que faz exercício, que cuida de si, pensando nos outros. Estavas na Bahia e gostavas de ver quem passava de navio. Vinha gente do Norte e do Sul, descia, saía contigo para olhar igrejas, praias e antiquários. Contavas uma porção de histórias e todos achavam muita graça. Ia contigo ao almoço na melhor comida da terra e ao banho de praia mais serena. Davas uma ordem e os atabaques de um candomblé começavam a bater, embora não fosse o tempo. Pai de Santo te levava ao pegi e dava explicações para os teus convidados. Depois da função, ainda meio transidas, as ogans vinham sorrir e te abraçar. Os teus amigos se encantavam com o teu prestígio. O teu show era tão completo e, dele, falavam tanto que, tempos depois, quem fosse passar em Salvador já te mandava telegrama, porque percorrer a cidade, sem ser pela tua mão, até nem tinha graça. E assim conheceste uma porção de gente - jornalistas, poetas, moças, políticos, artistas, viajantes de perfumarias e laboratórios. Na época das festas, estavas sempre com os capoeiristas e sambeiros, na Conceição da Praia, no Bonfim e na Ribeira. Na tarde de Iemajá, ias, com os pescadores, e levavas uma braçada de rosas para Janaína. Não acreditavas em nada daquilo, mas, 
era uma festa de flores e canções, que te enchia de muita beleza. Além disso, os pescadores e mestres de saveiros gostavam de ti e não perdoariam a tua falta, a 2 de fevereiro. Esta fotografia foi tirada em 1946. Teu jeito, diante do que está na carteira de identidade, é de um homem que já viveu um pouco e ainda pensa em viver muito mais.

Dá uma espiada, agora, no retrato do teu passaporte. É recente. Que é daquele meio sorriso de vitória, que é do bigode de tendências esquerdistas? E os ombros, e o peito de nadador? Onde deixaste os teus cabelos, que nunca foram belos, mas eram tantos, a ponto de te dar trabalho de manhã, com pente e escova? E os teus olhos? Estão cheios de tristeza. Os outros não notam, porque eles são pequenos e ninguém acredita que tristeza muita possa caber dentro deles. Mas, volta aos dois antigos retratos e vê o jeito e o brilho do teu olhar - vivo, mandão, crente e aventureiro. $\mathrm{O}$ de hoje nada mais faz que pedir. São olhos como as tuas canções, que essa gente canta e nelas se mistura, sem se lembrar de ti, sem se aperceber de que cada uma é história tua, sem ao menos te agradecer pelo que disseste. Não estás morto, eu sei, mas, feneceste, moço. A culpa não é do Almirante Jaceguai, que saiu contigo, ensinando-te a ser vagabundo. Mas é do carrilhão do vizinho gemendo os quartos de hora: é das tuas dores e das dores dos outros, que te comovem tanto.

Em São Paulo, na mesa escondida no fundo de um bar, viajaste através de ti mesmo, durante longos anos. Teu documento de identidade, tua carteira de motorista e teu passaporte foram portos de escala e neles pensastes estas coisas. Naquela hora, porém, apesar das dezenas de pessoas, que entravam, bebiam, falavam e saíam - ignorando-te - uma certeza te salvou: longe, devia haver alguém que estava pensando em ti. E, se não houvesse era só porque estavas meio bêbedo... e ninguém gosta de pensar nos bêbedos.

São três os Marias elencados de acordo com as fotografias dos documentos: o primeiro, da distante juventude, é o da carteira de identidade e está conectado ao ita, à embarcação que o levou ao Rio de Janeiro. O segundo, da juventude assentada, se conecta à carteira de motorista, ao Cadillac. E o terceiro, da maturidade, ao passaporte do avião. Todos os 
períodos se relacionam a meios de transporte. As identidades revelam as enormes distâncias que separam um Maria do outro. A ideia de partida é o que reúne os diferentes momentos da vida, tudo narrado de fora e de dentro: "Em São Paulo, na mesa escondida no fundo de um bar, viajaste através de ti mesmo".

O "rapazola do Recife", de 1940, vivia de "muitas esperanças" - aspirações que esperava realizar na capital. Desde o primeiro momento de sua jornada, confiou nas "histórias inventadas" como modo de conduzir a vida, de se inserir nos meios, de fazer sucesso na roda de moças. A carteira de identidade, apresentada aos incrédulos em relação à sua idade, era um salvo-conduto. "Acharam que tu eras um prodígio". De certo modo, o jovem Maria estava à frente do seu tempo. "Até hoje", continua, "não fizeste outra coisa, senão inventar histórias para engabelar e conquistar os outros”.

O Maria de 1946, que sabe dirigir um automóvel, representa o ápice da juventude no sentido de vitalidade, de vigor. Cuida do seu corpo pensando nos outros. Na Bahia, a estratégia de contar histórias vingou, e agora o cronista colhe os frutos de uma ampla sociabilidade: conversa com turistas, políticos, artistas, pescadores. Gente de fora e gente de dentro. A noção de performance, neste parágrafo traduzida pela ideia do show, permanece. "Contavas uma porção de histórias e todos achavam muita graça". Espécie de senhor da terra e do tempo, comanda os atabaques dos terreiros. No candomblé, o atabaque é o instrumento sagrado que conduz o axé dos orixás. $\mathrm{O}$ cronista aparece tão conectado às pessoas e ao local que bem poderia estar "encantado", segundo as noções de energia vital do candomblé. ${ }^{33} \mathrm{Na}$ Bahia, Maria não estava à frente do tempo, mas plenamente conectado ao agora. O presente é o equilíbrio entre passado e futuro: “já viveu um pouco", mas "pensa em viver muito mais".

O terceiro Maria, de 1953, é o do passaporte, das viagens à Europa. Deixou para trás os traços do vigor jovial: "meio sorriso de vitória", "bigode de tendências esquerdistas", “ombros e peito de nadador” e o cabelo em fartura são elementos perdidos do passado. O olhar, antes “vivo, mandão, crente e aventureiro", agora é de tristeza. Uma tristeza não notada pelos outros. Como se, tendo conquistado a proeza do ofício artístico, tivesse sua essência anuviada pela própria obra. As pessoas cantam suas composições, leem suas crônicas, mas não o percebem. "Não estás morto, eu sei, mas, feneceste, moço".

\footnotetext{
${ }^{33}$ Sobre as noções do candomblé, conferir SIMAS, Luiz Antonio. O corpo encantado das ruas. Rio de Janeiro: Civilização Brasileira, 2020.
} 
Desbotou, como fotografia. Pelas dores próprias e pelas alheias que tanto o comovem, o cronista amadureceu ao se dar conta do custo natural da vida. Triste e vulnerável, o Maria da década de 1950 olha para o passado.

Rompendo o fluxo de futuro-presente-passado estabelecido pela trajetória de Maria ao longo dos anos, uma quarta voz aparece. Essa voz passa a ser uma espécie de cristalização de seu estilo. Antônio Maria encontrou timbre próprio. Com tanto empenho afetuoso de sua parte, a solidão em que se encontra não é uma conclusão lógica. No entanto, justifica suas escolhas: a certeza de que alguém distante pensa nele é um consolo para a tristeza, mas também um sentido para tudo. Na quarta fotografia, figura fora do mapa sentimental, está em trânsito livre pela vida.

\section{PLANTÃO NOTURNO: REALIZAÇÃO LITERÁRIA}

Três meses depois de começar a publicar na Manchete, Maria vira colaborador do jornal Diário Carioca (1928-1965), que fazia oposição a Getúlio Vargas e apoiaria a candidatura de Juscelino Kubitschek. Para quem não tinha conseguido manter a regularidade de uma única coluna, a decisão de acumular duas soa insensatez de glutão. Independente de ser ambição desmedida ou irresponsabilidade do menino grande, a coluna "A noite é grande" circulou diariamente entre fevereiro de 1953 e janeiro de 1955.

A nova vida dupla de cronista de Antônio Maria permite uma pequena digressão sobre os rumos da crônica moderna diante da entrada das grandes revistas. No jornal, as crônicas de Maria tinham em média 2.000 caracteres, contra quase 4.000 da Manchete. No jornal, a coluna era apenas um box discreto, sem ilustração ou adorno, entre programações culturais, registros sociais, previsões astrológicas e outras pequenas colunas, como "Primeiro plano", de Paulo Mendes Campos e "A noite tudo encobre", de Fernando Lobo. Na Manchete, a crônica tinha direito à metade de página, destacada por um fundo neutro, do topo ao rés do chão.

O espaço físico pode ter sido um elemento decisivo para que o cronista dispensasse à coluna do jornal um outro registro. Escrevendo simultaneamente para a Manchete e para o Diário Carioca, cria-se um contraste interessante entre a crônica de revista e a clássica do jornal. No espaço mais amplo e prestigioso, a literatura se desenvolve à vista. No confinamento do jornal, a experiência urbana também se plasma 
em literatura, mas o lirismo que resulta da interpretação das dinâmicas da cidade nem sempre é forte o suficiente para subjetivar a crônica. Muitas vezes, os textos do Diário Carioca não vencem a barreira jornalística da opinião.

Da perspectiva do tempo, a pressão diária do jornal se contrapõe à respiração dilatada da revista semanal. As entregas semanais permitem um melhor acabamento das crônicas. Outro fator decisivo é a diferença entre os tipos de leitores. A Manchete atraía um público jovem feminino, com maior poder aquisitivo e ávido por imagens do mundo. Além disso, tinha uma tiragem expressiva e uma ampla distribuição, atingindo leitores de diferentes regiões do país.

Apesar de todos os aspectos favoráveis, em dezembro de 1953, Maria deixa de colaborar com a Manchete e segue no Diário Carioca. Um mês depois, no entanto, assume uma coluna na decadente Revista da Semana, que contava com a direção de Joel Silveira e circularia ainda por cinco anos. Em oposição à degradada popularidade da publicação, o tratamento dado a Maria era de grande destaque: pela primeira vez, o cronista dispunha de uma página inteira, batizada de "Plantão noturno", e tinha direito a uma ilustração, também em página cheia, na folha ao lado.

Como sempre, o título da coluna valoriza a dimensão afetiva e furtiva da noite, dos encontros e das vivências amorosas. A obra de Antônio Maria não se compreende à luz do dia. De fôlego notável, o conjunto praticamente inédito em livro revela uma aproximação maior com a literatura, menos preso à matéria cotidiana e documental. Alguns vícios jornalísticos praticamente desaparecem. E o manejo de estratégias diferentes, que já tinha se revelado no período da Manchete, reaparece como força renovada. Além dos amores e encontros da noite, a gastronomia e o futebol são temas centrais. Também figuram as crônicas clássicas de observação, em que o cronista se posta diante do mundo para reequilibrar pequenezas e recalibrar grandezas.

Uma das notáveis, "Everaldino com saudades", aparece no número 24, em 12/6/1954, cujo poder de imaginação ilumina o domínio técnico do escritor. A crônica também traz, em outros níveis, o processo de desnudamento que Maria praticava em sua literatura. Para melhor aproveitar a análise, a transcrição se dará aos poucos:

Everaldino, nome da Bahia, mãos e cabelos de melhor baiano. Encontrá-lo num restaurante da noite, em São Paulo, com ele comer carne e arroz, era uma coisa assim igual a estar no Café das Meninas, 
em Salvador. Seu ar e sua voz macia baianizavam por completo o salão, onde paulistas friorentos comiam. Contava suas histórias. Saiu da Bahia, como taifeiro, e foi andar pelo mundo.

O cronista e Everaldino, homem que viajou o mundo e acumula variadas experiências de vida, se encontram à noite num restaurante de São Paulo. A descrição de Everaldino é espaçada e lacunar, o que faz com o que o personagem ganhe camadas de significação apenas com o desenrolar da história.

A primeira coisa que sabemos de Everaldino diz respeito à terra natal: "nome da Bahia, mãos e cabelos de melhor baiano". É verdade que Maria tinha fascínio pela Bahia, e que o tema reapareça com frequência em suas crônicas. Mas o destaque tem, aqui, novos significados. "Seu ar e sua voz macia baianizavam por completo o salão, onde paulistas friorentos comiam", continua. O ritmo e a voz calorosa do narrador transportam leitor e ouvinte para outra realidade. "Era uma coisa assim igual a estar no Café das Meninas", um ambiente de convivência intelectual de Salvador, frequentado, entre outros, por Jorge Amado. Comparar a conversa de Everaldino, homem humilde com quem se divide um prato de carne e arroz, a um ambiente intelectual, revela a admiração do cronista por aquele homem.

São Paulo, para onde Maria se deslocava semanalmente para fazer programas na TV Record, costuma penetrar em sua literatura pelo viés gastronômico. A crônica ambientada por lá geralmente evoca um restaurante, a ronda noturna, a roda de amigos. Neste caso, a capital paulista adquire significado extra, pois é o ponto de encontro entre dois exilados: o baiano Everaldino e o pernambucano Antônio Maria. A distância da terra natal fornece a base estrutural da narrativa.

A primeira coisa importante que se diz de Everaldino é que "contava suas histórias", o que traz à tona a oralidade do narrador primitivo. Temos, então, um relato em segunda mão: o cronista nos reconta o que ouviu de Everaldino, cuja voz só aparece diretamente em breves passagens.

Várias coisas cometeu pela vida afora, até ser escafandrista, no Golfo da Biscaia, trabalhando para um barcaceiro grego, que se chamava Papaulus. Sem querer, sem provocar, ficou amante de Maria, mulher de Papaulus, descendente de espanhola e - disse Everaldino - "a dos olhos cinzentos". Não sabe o que o levou para ela: talvez tenha sido o olhar, 
da cor das tardes chuvosas, da cor dos nevoeiros no mar. Talvez tenha sido a mão macia, que lhe afagou a cabeça, numa noite de febre. Talvez tenha sido simplesmente a solidão de um baiano exilado, largado por caminhos que só vira em nome - sem sonhá-los - nas aulas de geografia do primeiro ano de ginásio. Não fora (disso tinha certeza), apenas, pelo prazer de trair.

E a história começa assim: Everaldino saiu da Bahia para o Golfo da Biscaia, entre as costas da Espanha e da França, e foi trabalhar para um barqueiro grego chamado Papaulus. Entre Papaulus e Everaldino há mais do que um oceano. Um nome sugere a grandeza mitológica, os livros de história. Outro, uma realidade terrena e humilde. ${ }^{34}$ E o abismo entre Grécia e Bahia é a chave sutil com que se constrói, na linguagem e no ritmo sintático, uma conexão entre patrão e empregado. Justamente por haver tantas diferenças marcadas, ela saltará à vista do leitor e se transformará em algo maior.

Acontece que o baiano, "sem querer, sem provocar", ficou amante da esposa de Papaulus, Maria. A naturalidade com que se desenrola a traição é reforçada pelas incertezas do relato, tornando impossível distinguir o que é fala de Everaldino do que é juízo de valor do cronista.

O carinho na noite de febre disfarça o desejo, transformado em necessidade de cuidado. Os olhos da cor dos nevoeiros e das tardes chuvosas não são, simbolicamente, atraentes. Mas o são para um exilado solitário, porque o viajante tem uma relação de intimidade com a chuva, a névoa e o mar. Distante de casa, sem um teto seu, está desprotegido. O cinza ilustra a difícil beleza das coisas indefinidas, oscilando entre a brasa e o pó, calor e frio, claro e escuro. Enquanto essa personagem feminina se configura no campo do cinzento, os dois homens parecem incapazes de fugir dos extremos. A imagem da febre remete ao delírio de um desejo que, aplacado com mãos macias, compõe uma unidade algo contraditória.

O desterrado Everaldino, cuja simplicidade vem à tona com a menção aos estudos interrompidos, tem, assim, a traição naturalizada, descrita de modo sereno, com frases curtas e objetivas. É uma frequência inusual de orações assindéticas para o gênero. Nas

\footnotetext{
${ }^{34}$ Segundo o censo de 2010 do IBGE, a Bahia detém a maior taxa de ocorrência do nome Everaldino, cujo índice de registros atingiu um pico entre as décadas de 1950 e 1960. Trata-se de nome quase exclusivamente baiano. Papaulus, por outro lado, apresenta apenas 380 resultados numa busca do Google, o que indica ser fictício.
} 
crônicas de Antônio Maria, não há necessidade moral de justificar a traição. Esse traço o distingue de muitas outras crônicas da época. Em especial de Nelson Rodrigues, seu conterrâneo.

Em 1951, a convite de Samuel Wainer, Nelson passou a publicar na Última Hora textos que retratavam situações da vida real com forte carga ficcional e dramática. A coluna “A vida como ela é...", dez anos depois compilada em livro, estampava os dilemas morais e sexuais da família tradicional do subúrbio carioca. Fez grande sucesso popular. O ciúme, a inveja obsessiva e a traição são centrais nas histórias, que sempre acabam em sangue. O personagem Everaldino seria incapaz de se desenvolver com profundidade no texto rodriguiano. Provavelmente morreria assassinado pelo patrão. Nesse sentido, é interessante observar como Maria usa esses elementos para compor a estrutura de sua crônica, formatando um universo particular de Everaldino, denso o suficiente para gerar empatia no leitor.

A voz de Everaldino quase não aparece diretamente. No primeiro parágrafo, irrompe em dois momentos: na descrição dos olhos da mulher e na certeza de que não virara seu amante pelo "prazer de trair". A frase levanta outras questões. Há algo da vida excessiva de Antônio Maria que transparece na escolha da expressão "prazer de trair".

Papaulus era um homem grave e vagaroso. Não perguntava nem contava histórias. Um dia, era tarde, viu Maria sair de um abraço do amante e desaparecer no corredor, que dava para a cozinha, consertando os cabelos. Sentou, pediu (a Everaldino) que lhe trouxesse a garrafa de Genebra, começou a beber e avisou que haveria mergulho na manhã seguinte. Everaldino preferiu sair para embriagar-se na rua, em companhia de pescadores seus amigos. Só voltou na hora em que tinham de sair para o mar. Sem dizer nada, foram os dois para o ponto onde seria o mergulho. Teriam que refixar uma boia - avisara o chefe e, olhando com dureza os olhos do baiano, ajustou-lhe o redondo e feio capacete de escafandrista. Everaldino compreendeu que ia para a morte e sentiu o fundo do mar como um consolo e um descanso, uma punição e uma eternidade. Escorregou, devagar, pelas beiras do barco e sumiuse.

O segundo parágrafo mantém uma relação com o primeiro, muito similar à conexão de Everaldino com Papaulus, misto de oposição e sintonia. O baiano e o grego, afastados por 
elementos formais e simbólicos, estão vinculados por um código ético característico da conduta masculina do que não é dito, em nome do qual as diferenças serão superadas. Isso se evidencia quando Papaulus é descrito de maneira quase idêntica à de Everaldino: "Papaulus era um homem grave e vagaroso". E, a seguir, a diferença definitiva: "Não perguntava nem contava histórias". Se o baiano pertence ao universo da oralidade que fascina o cronista, o grego se pauta pelo silêncio. Posicionamentos diametralmente opostos em relação ao mundo.

E com a mesma naturalidade com que Everaldino se envolve na traição, certo dia Papaulus nota o que está acontecendo - "mas era tarde", aparece a voz do cronista sobreposta ao relato, como se entendesse bem a situação. Papaulus reage friamente, distante de emoções, recusa o diálogo. Um tipo de sistema primário e automatizado que não permite nada se desdobrar. Tudo é tomado em sua instância primeira: um homem trai e não descreve o ato; um outro descobre que foi traído e não desenreda o fato; um terceiro narra a trama com igual distanciamento.

A linguagem também se adapta ao código: concisa, breve, seca. Como convém ao entendimento masculino. A presença discreta da parataxe é suficiente para causar estranheza ao gênero literário, pouco afeito à sensação de sufocamento e de acúmulo das orações assindéticas. Esse universo, como todo sistema vedado, age acima das relações humanas. É por isso que Everaldino compreende a morte quando Papaulus olha com dureza em seus olhos. Tudo é intenso e manso. Everaldino traiu sem o prazer da traição. Papaulus se vingou sem o prazer da vingança.

Não sabemos se os outros marinheiros estavam presentes no momento. É possível pressupor, pelo ambiente coletivo de um barco, que estivessem. Mas o sistema masculino é composto com tanta coerência que ninguém, nem mesmo a amante, seria capaz de interceder pela vida do baiano. Tudo corre como tem de correr. Sem necessidade de defesa ou julgamento, Everaldino sequer reflete sobre a morte, nem se despede de ninguém. Apenas aceita. $\mathrm{Na}$ ambiguidade dos pares consolo/descanso e punição/eternidade, a morte aparece como o custo das experiências de vida clandestina dos exilados, despatriados, dos dépayses -, daqueles que perderam o norte, expressão que se encaixa com extrema ironia no caso dos nordestinos Everaldino e Antônio Maria.

Passaram-se os primeiros minutos, passou o tempo normal de imersão. Poderia ter tocado a campainha, apelado para o perdão do grego, mas 
não quis. Esperaria a morte, dentro do capacete de ferro. As algas e os peixes eram visões de despedida. E a transparência do verde lhe enchia de beleza o último dos mundos aos seus olhos. Foi quando sentiu um puxavante e, devagar, começou a ascender. Papaulus podia tê-lo deixado morrer e seria ali, sem denúncias, sem punição. Mas, não quisera. Trazia o mergulhador outra vez para o barco e, num gesto de grandeza, apertava-lhe a mão (sem sorrir, olhando-o outra vez com dureza) premiando-lhe a coragem de não ter pedido para salvar-se. Everaldino conta que, da praia mesmo, tomou rumo de viagem. Nem fora - embora quisesse tanto - olhar, pela última vez, os olhos cinzentos de Maria.

Everaldino não salta nem se joga: "escorrega" para o mar. A concisão dita o ritmo da crônica, o tempo todo em rédeas curtas. E nem mesmo submerso o personagem rompe o pacto silencioso: não pede socorro nem perdão. Apenas espera a morte, contemplando o fundo do mar com os olhos de quem vai morrer.

Coerente com a estrutura formal do texto, o olhar desempenha um importante papel na construção dos personagens, descartando os diálogos ou a descrição pormenorizada. A amante espanhola, que navega em zonas de indefinição, tem os olhos cinzentos. O grego só fala através do olhar duro, dispensa as palavras. E o baiano tem os olhos disponíveis, abertos às coisas do mundo. A construção fica latente a partir das imagens evocadas na cena da submersão, cuja tensão é distendida por um ritmo calmo, provocando no leitor a estranha sensação de que é possível aceitar uma situação absurda com naturalidade.

Os detalhes ganham força, sublinhando as ambiguidades do contraste harmônico: contra a pressão d'água, o capacete "de ferro"; a vida submarina, algas e peixes, são "visões de despedida"; "a transparência do verde" enche os olhos de beleza. O fim do mundo no fundo dos olhos. Eis que aparece a redenção de Everaldino, também reconfigurada: não é um milagre, mas “um puxavante”. Papaulus traz o baiano de volta, cumprindo seu papel na ética masculina porque Everaldino cumprira o seu. E Everaldino, emergido, parte imediatamente, sem nenhum pertence, seguindo a vida pelo mar, como convém a um aventureiro.

Dali, andando sempre pelo mar, foi ser baterista de uma orquestra cubana, em Singapura. Eram seis músicos e, de cubano mesmo, só havia 
o pianista, que se chamava Juan de Luca. O maraqueiro era francês, o pistonista italiano e tanto o guitarrista como o rapazote da clarineta eram argentinos. Deixou a orquestra, um ano depois, para aventurar com tráfico de tóxicos, em Lourenço Marques. Everaldino me contava essas coisas mastigando, fazendo pausas como se quisesse gozar cada saudade, rindo de um ou outro pormenor que lhe vinha à lembrança. Por exemplo: Annie, a francesa que vendera toda a roupa de dentro para almoçarem juntos. E lamentava-se: "não conheço Paris; não passei do Havre".

O tom da narrativa assume ares tragicômicos - estilo que também comporta características opostas. Cômico porque os relatos sucedidos soam quase aleatórios. Trágico porque o leitor, ciente de como Everaldino se conecta com o mundo, é incapaz de relevar sua profundidade. O que vivenciou debaixo d'água foi tão intenso que todas as situações posteriores ficam reduzidas ao ridículo. A proximidade com a morte oferece ao homem a dimensão real das coisas. O momento de extrema solidão no fundo do mar redimensiona todas as outras experiências de deslocamento.

O movimento de descida e ascensão tem ecos do mito de Orfeu. Após flertar com a figura do poeta da mitologia ocidental, vira baterista de uma orquestra em Singapura, composta por argentinos, franceses, italianos e cubanos. Depois, traficante em Maputo. E neste momento, durante a mais extrema das aventuras de Everaldino, o cronista interrompe o relato para observar o prazer detido nas expressões do baiano enquanto conta suas histórias, o que reforça a admiração nutrida por Antônio Maria: "Everaldino me contava essas coisas mastigando, fazendo pausas como se quisesse gozar cada saudade, rindo de um ou outro pormenor que lhe vinha à cabeça”. Passa por Paris e retorna à Bahia, sua casa, agora como clandestino:

Dez anos depois, voltava à Bahia como clandestino. As ruas eram as mesmas, a vista do mar, olhada das janelas dos fundos, em um sobrado da rua Chile, também era a mesma: saveiros, barcaças, o forte de $\mathrm{S}$. Marcelo, a rosa dos ventos encravada no ladrilho da escola dos marinheiros. Mas, os amigos, que tinham sido três, tinham ido correr mundo também. Um estava no Rio - soubera - vendendo essência de extrato francês. 
A atenção às barcaças, aos saveiros e à escola de marinheiros sugere uma predisposição de Everaldino em relação ao mar, ao desconhecido. A rosa dos ventos é o símbolo máximo do deslocamento. Mesmo quando fala de sua Bahia, a rua destacada é a rua Chile. Assim, se realça a naturalidade com que os fatos se sucederam. Quase como se tudo tivesse começado porque tinha de ser - "sem querer, sem provocar".

Mais um navio levou Everaldino, de terceira classe, até onde o dinheiro dava: Vitória do Espírito Santo. De lá, para seguir viagem, teve que lutar, num circo, contra um canguru, por trezentos mil réis. Empatou.

O terceiro parágrafo é o mais curto e tem uma força de resumo, realçando a figura do homem sem apegos, gastando tudo em seu constante deslocamento. O cômico empate contra um animal, a princípio vexatório, traz à tona a postura de Everaldino diante do mundo: sua masculinidade não se faz pela conquista ou pela força física, mas pela conexão e pelo entendimento das coisas, pelas experiências de vida e, sobretudo, pelo relato. Everaldino não enfrentou Papaulus. Aceitou a morte para ver o mar como último cenário.

Há algo de Everaldino em Antônio Maria. O senso de aventura que o fez sair de casa. Um posicionamento de sensibilidade diante do universo masculino. Certa inclinação ao entendimento das coisas, ao desejo de estabelecer vínculos. Maria não se fixava no mesmo bar: circulava por todos. Era seu jeito de abraçar o mundo e alcançar alguma completude.

Perguntei-lhe, então, de tudo o que tinha feito, de que tinha gostado mais. Respondeu-me que só foi realmente feliz quando era farol de caricaturista, em Roma. Posava, nos cafés, para um jovem italiano chamado Adolpho, que sabia fazer seu perfil muito bem feito. Acabamos de comer. O garção trazia a nota que, com gorjeta, dava cem mil réis. Everaldino fez questão de pagar. Na saída, pediu-me duzentos emprestados. Despediu-se e, bem jantado, com crédito no restaurante e cem mil réis no bolso, dobrou na esquina da rua Aurora. Fiquei olhando-o, com inveja de um homem vivedor. Alguém bateu no meu ombro e tirou-me do êxtase. Era Dermival Costa Lima, que chegava em passo vagaroso.

No quarto e último parágrafo, a voz do cronista aparece pela primeira vez de modo claro para fazer uma pergunta. Poderia ter perguntado mil coisas da ordem do épico, do intenso, 
mas quer saber de que mais tinha gostado de fazer. Sua curiosidade é reveladora. A felicidade, para o cronista, transparece como ideal. E com toda a singularidade da vivência de Everaldino, sua resposta surpreende: só foi realmente feliz quando esteve parado. $\mathrm{O}$ que poderia ser uma ruptura aparece com naturalidade, porque esses homens se entendem. A frase que se segue, marcada pela irmandade do plural, não deixa dúvidas: “Acabamos de comer".

Everaldino desempenha papéis diferentes com igual grandeza. Sua integridade, frágil diante de um mundo que não a valoriza ou sequer a percebe, não se desfaz jamais: na hora de ir embora, faz questão de pagar a conta mas pede emprestado ao cronista, que fica parado, admirando sua partida, "com inveja de um homem vivedor". O adjetivo "vivedor" define o espírito que atravessa toda a crônica. O desfecho vem com a mão pesada de Dermival Costa Lima, empresário do mundo do rádio e da televisão, batendo no ombro do cronista. Fora do êxtase, o peso da vida real se impõe ao devaneio idílico do cronista, como se o afastasse da possibilidade de ser, ele mesmo, um pouco Everaldino.

A crônica é uma boa amostra do período de Maria na Revista da Semana, um escritor maduro, inteiramente livre, se aprofundando com sinceridade nos limites do gênero. Segundo Antonio Candido, a capacidade de explorar uma situação limitada com "gratuidade artística" é indispensável aos prosadores dos gêneros breves, pois tanto os cronistas quanto os contistas

sentem que, sob a futilidade aparente da anedota, da ocorrência singular e do puro arabesco intelectual, podem ocultar-se verdades que o romancista só desvenda por meio de sequências mais longas, num contexto que ambiciona refazer o ritmo da vida, enquanto o conto só visa a um momento significativo e literariamente depurado. (CANDIDO, 2006, p. 62)

Nesse momento, o cronista Antônio Maria alcançou um novo patamar, descobrindo como desdobrar "um momento significativo" com autonomia literária, sem a necessidade de se ancorar em nada. Pela primeira vez, não se vale de elementos da memória pessoal. Transitando entre o épico, o lírico e o trágico, sua crônica conquistou o terreno da imaginação, ultrapassando o mapa sentimental da lembrança. Não fala de Recife, Fortaleza, Salvador nem do Rio de Janeiro, mas do mundo. É como se tivesse validado o passaporte diplomático de cronista. 


\section{CAPÍTULO QUATRO}

\section{MESA DE PISTA: ALTA SOCIEDADE}

A maturidade literária chega em um momento pessoal extremamente conturbado. Além dos muitos programas de rádio e televisão, o cronista assinou nada menos que três colunas simultâneas: "A noite é grande" no Diário Carioca e "Plantão noturno" na Revista da Semana eram semanais, enquanto "Mesa de pista", no jornal $O$ Globo, circulava diariamente. ${ }^{35}$ Mais uma vez, Maria quis abraçar o mundo. Precisou de quatro meses, de outubro de 1954 a janeiro de 1955, para perceber que não daria conta. Logo deixou a Revista e ficou com os dois jornais, até assumir monogamicamente a colaboração com $O$ Globo, de Roberto Marinho.

De sua lavra no Diário Carioca, onde colaborou de fevereiro de 1953 a janeiro de 1955, muitas crônicas foram compiladas em livro. É um momento de realização literária. A experiência seguinte, no entanto, toma outro rumo. Depois de encerrar as colunas "A noite é grande" no Diário Carioca e "Plantão noturno" na Revista da Semana, Maria inaugura "Mesa de pista" no jornal $O$ Globo, onde publica diariamente de outubro de 1954 a junho de 1959. É o mais longo período de contribuição contínua, embora seja, como os outros, marcado por irregularidades de entrega.

Se alguns anos antes sua prosa estava à frente dos demais cronistas noturnos por compreender a dimensão da noite em sua amplitude, com "Mesa de pista" Maria retrocede na comparação com os colegas de ofício. Nesse sentido, os títulos são bastante reveladores: em "A noite é grande" o cronista saía pelas ruas em busca de novas paragens noturnas, mas em "Mesa de pista" ele se fechava dentro das boates. Representa um passo atrás para a ambição literária, mas dois adiante para sua latente necessidade de contato social e aceitação pessoal.

Em detrimento da literatura, "Mesa de pista" sinaliza um desejo de se afirmar na vida social. Mais do que isso, de conduzi-la. Para abarcar todo tipo de comentário sobre as casas noturnas, Maria faz de sua coluna uma espécie de jornal em miniatura. O número de estreia, de 5/10/1954, traz uma foto de Dolores Duran, menções a bares novos, uma piada, recomendações de espetáculos e um texto curto. Um mosaico em tom pessoal de aleatoriedades desconexas, unidas pelo interesse de emoldurar a alta sociedade que

\footnotetext{
${ }^{35} \mathrm{Na}$ verdade, com o tempo, a frequência da coluna do Diário Carioca variou entre diária e semanal, numa clara demonstração da incapacidade de Antônio Maria em cumprir prazos.
} 
frequentava esses ambientes. Por lá, passaram todas as personalidades da noite carioca. Aos amigos, notas de elogio. Aos desafetos, elegantes maledicências.

Embora não seja possível mais falar em literatura, Maria empenha algumas características do ofício de cronista: um olhar observador, do qual às vezes se apreende algum resquício de lirismo, e uma disposição de se maravilhar com descobertas insuspeitas. Durante os quase cinco anos de coluna, experimentou muitas possibilidades formais, da junção de várias notícias comentadas a um único texto longo. A ausência de forma fixa possibilitou, em alguns momentos, a publicação de crônicas. No entanto, o movimento geral da coluna é mesmo em direção ao colunismo social. Contou, inclusive, com colaboradores, como Lourdes Lessa, irmã da cronista Elsie Lessa.

O que teria feito Maria se afastar da literatura? Depois de alcançar o ponto alto de sua carreira na Manchete, no Diário Carioca e na Revista da Semana, afastou-se novamente do ofício de cronista. Revelam movimentos contraditórios de um homem inseguro. O período, agora, é de evidente retrocesso. Paralelamente, Maria colabora com O Semanário, jornal recém-fundado por Joel Silveira com redações no Rio e em São Paulo. Com forte inclinação cultural, publicava poesia e uma crônica curta de Rubem Braga na última página. Maria escreve somente em seis edições, entre agosto e dezembro de 1956, numa coluna de nome "Dia e noite" que acolhe pequenos comentários sobre acontecimentos da semana, sem interesse literário. A impressão é a de um escritor que desiste quando está prestes a ser publicado - alguns

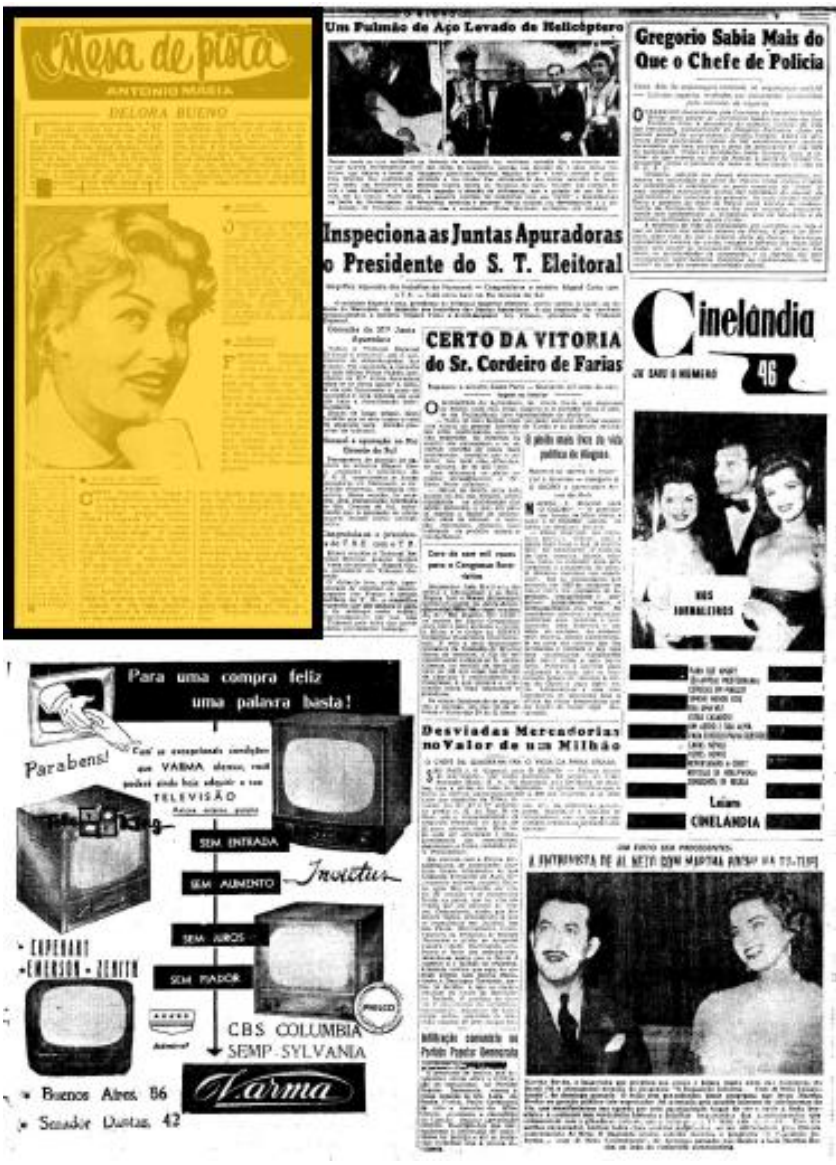
anos antes, tinha conquistado os espaços mais prestigiosos da imprensa, gozava de popularidade, tinha um ótimo domínio do texto. O próximo passo seria, naturalmente, editar um livro de crônicas. Mas quando a possibilidade surge, Maria pisa no freio. 


\section{ROMANCE POLICIAL DE COPACABANA: SUBMUNDO CARIOCA}

Em junho de 1959, a "Mesa de pista" se encerra. Em agosto, Maria retorna às páginas da Última Hora, de Samuel Wainer, por onde já tinha passado brevemente em 1952. Tendo atravessado um período de certo vazio literário, assume uma atividade excêntrica em sua carreira: uma coluna policial. O interesse da imprensa pelo assunto é consequência da guinada violenta que começava a tomar conta do Rio de Janeiro. Zuenir Ventura, em seu livro-reportagem Cidade partida, registra que a percepção da violência urbana começa a ter mais destaque na imprensa a partir de 1953:

No início desse ano, ela [a imprensa] se surpreendeu com o "recorde excepcional" de tumultos e mortes no réveillon, quando a radiopatrulha teve que atender, em menos de doze horas, a mais de duzentos chamados. "Com efeito", assustava-se a revista Manchete, "1953 chegou à Cidade Maravilhosa encharcado de sangue". (1994, p. 20)

A sociedade se reconfigurava, e Wainer soube explorar bem a situação. Fez com que seu jornal popular, vendido a cinco cruzeiros, orbitasse o cotidiano das delegacias. Toda a Última Hora foi pautada em função disso:

Samuel Wainer pregava nas reuniões do aquário: "O fato policial tem que ser de qualidade. Tem que ser humanizado e romanceado". Como se fosse possível humanizar a violência. [A coluna] "Coisas da vida e da morte", mantida inicialmente por Luís Costa [...], conseguiu realizar essa humanização. Seguia a linha rodrigueana de "A vida como ela é...", sem abandonar a veracidade que se espera de uma história jornalística, ainda que romanceada. [...] "Romance policial de Copacabana", de Antônio Maria, foi também êxito de reportagemrelâmpago algum tempo depois. Maria escrevia sobre sentimentos vis e complicados de forma simples, fácil e digestiva. (PINHEIRO JR., 2011, p. 60)

Escalado para publicação diária, Maria passa dois anos completos, até agosto de 1961, frequentando os plantões de madrugada do $12^{\circ}$ DP de Copacabana, na rua Hilário de Gouvêa, 102, sob responsabilidade do delegado Hermes Machado. ${ }^{36}$ Com sua Remington portátil, sentava no bar Pavão Azul, em frente à delegacia, e observava o fluxo das

\footnotetext{
${ }^{36}$ Os textos de Antônio Maria falam da delegacia de Copacabana como o " ${ }^{\circ}$ DP". Assim aparece em seu perfil biográfico, de autoria de Joaquim Ferreira dos Santos, que usa " $12^{\circ}$ DP" para se referir à mesma delegacia em artigos posteriores. É possível que, à época do "Romance policial de Copacabana", a delegacia tivesse outra numeração e tenha sido atualizada de 2 para 12.
} 
ocorrências. O turno do trabalho lhe era conveniente, e a delegacia servia como última parada após a procissão pelas boates. O jornal atendia seu constante desejo por destaque, e fotografias do próprio repórter entrevistando os detidos eram frequentes. ${ }^{37}$

Pela primeira vez, Maria assume a voz de repórter. Se o formato the era novidade, não provocou nenhum estranhamento em seus leitores. Instigado pelo próprio jornal a florear os fatos, Maria escreve sobre os crimes passionais de Copacabana com o mesmo olhar lírico que costumava construir sua crônica. Pequenos registros de furto são elevados a dramas existenciais. De um simples bêbado, extrai um passado complexo. E uma queixa de agressão se desdobra em uma instigante trama de paixão desmedida. Pelas lentes curiosas de Antônio Maria, personagens da vida cotidiana são alçados à condição de protagonistas de grandes questões.

Talvez o "Romance" tenha surgido num momento pessoal oportuno. Em busca de retratar uma nova organização social, o repórter precisou se reinventar com a renovação temática. A matéria das ruas não lhe era estranha. As raízes do seu interesse

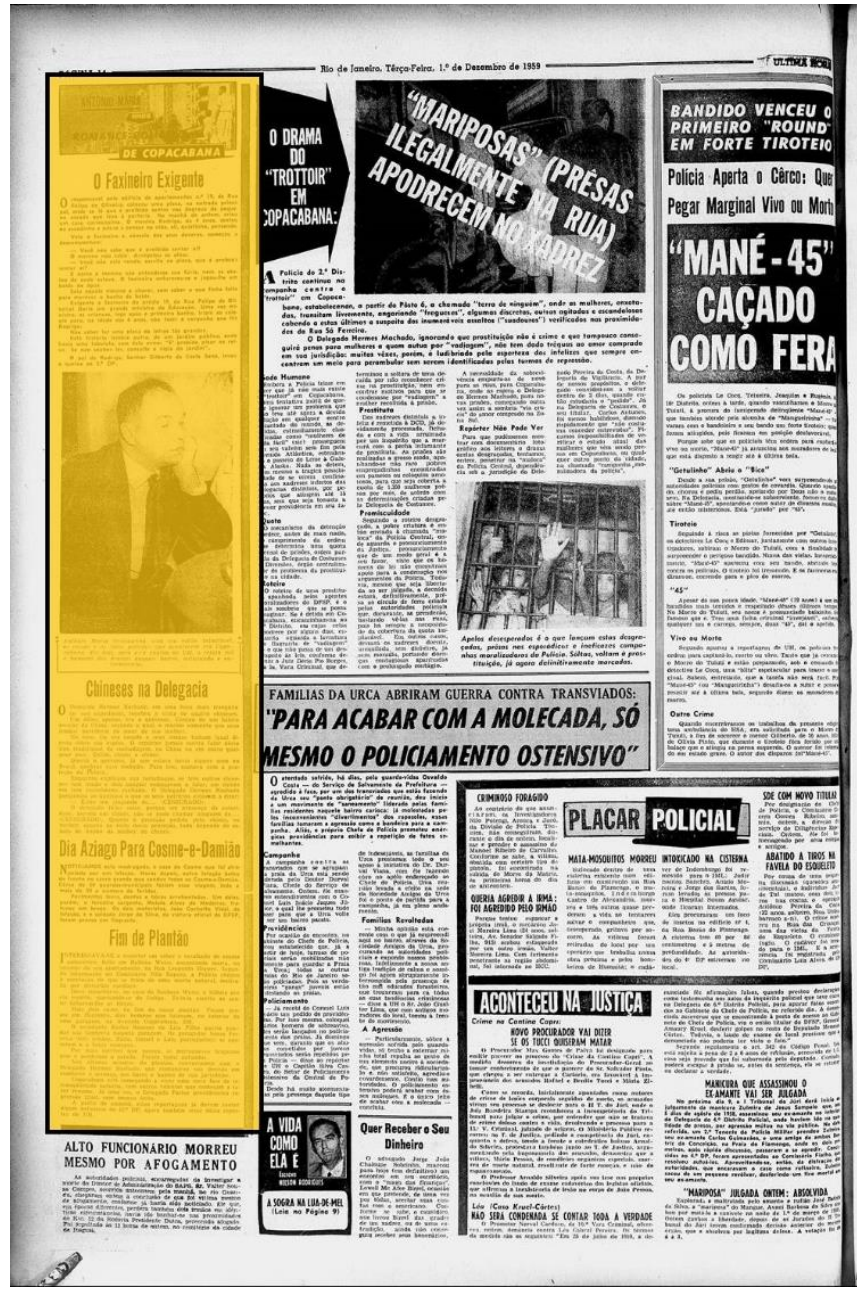
pela violência e pela simplicidade remontam às festas populares de Pernambuco, que acabavam em tiroteio. E o movimento que faz como repórter é bastante similar ao do cronista, lapidando e distorcendo elementos da vida real até revalar na sua medula narrativa. A rigor, as limitações práticas impostas pelo "Romance policial de Copacabana" não representam prejuízo para a ficção. No entanto, mesmo com similaridades técnicas, fica evidente que a mudança de departamentos adia ainda mais o antigo projeto de ser cronista em tempo integral.

Maria passa, então, do ambiente fechado das boates para a alvorada das calçadas de Copacabana. A mesma lente que usava para observar a roda viva dos círculos

\footnotetext{
${ }^{37}$ A coluna chegou a ser quadro de televisão, conduzido pelo próprio autor. Lasinha Luis Carlos registra no Correio da Manhã: "Antônio Maria, em seu 'Romance policial de Copacabana' da TV-Rio, tem uma curiosa especialidade: ensina ao povo tudo que ele não deve fazer. Sob o pretexto de advertir, sugere "não faça isto!', e explica direitinho como fazer".
} 
fechadíssimos da alta sociedade servia agora para tentar ampliar a reduzida margem social de mendigos e prostitutas. Ele, que já tinha vivenciado a experiência da prisão, conseguia desentranhar dignidade humana daqueles personagens diminuídos e oprimidos. Maria sabia transitar bem entre os dois territórios e, aparentemente, essa abordagem apaixonada do mundo ainda era possível. O crime organizado não havia se estruturado, e ainda era concebível falar sobre bandidos folclóricos, loucos abandonados, suicidas de amor e jovens arruaceiros à James Dean.

O repórter extrai grandezas desses pequenos personagens do submundo carioca, registrando com coração aberto detalhes ocultos dos delinquentes. Por extensão, evoca um lado invisível cada vez maior da metrópole. Nesse contexto de transição social de alguma inocência para a brutalidade escancarada, Maria vive o presente com o rosto virado para o passado. Rubem Braga, por outro lado, diante do mesmo cenário, tinha publicado um ano antes uma de suas mais famosas crônicas, “Ai de ti, Copacabana!”, em que anuncia em tom apocalíptico a derrocada moral do bairro:

Por que rezais em vossos templos, fariseus de Copacabana, e levais flores para Iemanjá no meio da noite? Acaso eu não conheço a multidão de vossos pecados? Antes de te perder eu agravarei a tua demência - ai de ti, Copacabana! Os gentios de teus morros descerão uivando sobre ti, e os canhões de teu próprio Forte se voltarão contra teu corpo, e troarão; mas a água salgada levará milênios para lavar os teus pecados de um só verão [...]. (BRAGA, 1960, p. 100)

Braga prenuncia o expurgo divino do alto de sua varanda, constatando o deterioramento das relações sociais. Maria, por sua vez, anda pelas ruas segurando a mão dos charlatões, enxergando neles a humanidade esmagada dos desvalidos. É o único modo de transformálos em personagens do "romance" aludido pelo título da coluna - em sentido bronco, como uma narrativa longa com vários personagens que evoca realismo e ficção, um grande compêndio de Copacabana.

Maria tratava cada uma dessas colunas como capítulos. O de 6/11/1959 é uma amostra da capacidade do repórter em descobrir histórias na banalidade da vida comum. 
"O caso (amoroso) de Pedro das Flores", sobre um homem arrependido pela separação, evoca um instante de lirismo pouco provável em uma delegacia:

No "Romance policial de Copacabana", há histórias que mereciam ser contadas com fundo musical de violão. Aquela "Serenata do adeus", por exemplo, do poeta Vinicius, seria a ária ideal, para se contar, com as mais líricas palavras da língua, o caso amoroso do Pedro das Flores.

Pedro das Flores, o mais romântico entre os homens noturnos de Copacabana. Sua vida é quieta e bonita. Pelo menos aparentou, até hoje. Em cada acontecimento, havia uma rosa, uma margarida ou uma orquídea. Sai de noite. Vai de bar em bar. Em cada mesa, onde encontra um casal de namorados, deixa, timidamente, uma flor. O namorado paga, se quiser, quanto quiser, porque Pedro diz sempre que "as flores não têm preço". Mas, o feijão, sim... por isso Pedro guarda no bolso, sem olhar, os 50 e 100 cruzeiros por botão de rosa, que deixa nas mesas dos namorados.

Pena que a passagem de um Pedro das Flores pela delegacia, sendo, como é, uma notícia lírica, encontre um repórter tresnoitado, sem tranquilidade de tempo e sossego, para escrever a crônica merecida. É uma história diferente das outras.

Pedro vivia com uma mulher, havia 34 anos. Fartaram-se um do outro. Desgastaram-se, mutuamente. Ela pediu para ir embora. Pedro consentiu e, num gesto de gratidão, entregou 50 mil cruzeiros à companheira. Passaram-se os dias e a mulher começou a fazer falta na casa e no coração de Pedro. Ah, florista, sua história é uma letra de samba já pronta. Só faltam as rimas, que Billy Blanco deverá fazer, como ninguém.

Ontem, Pedro compareceu ao $2^{\circ}$ DP. Quer a mulher de volta, de qualquer maneira. Com ou sem pecados. Quer que a polícia de Copacabana lhe traga o que era seu.

Pedro, você andou mal. Apesar de ver por aí tanta coisa, tanta história de amor dos outros, você errou, Pedro, em causa própria. Viu muito, mas aprendeu pouco. É sempre assim. Mulher a gente só manda embora depois de procurá-la bem em todos os cantos do coração (em todos os cantos da carne) e não encontrar. Mesmo assim, a gente não manda 
embora. A gente é que vai. E quem vai aprende o caminho de tornar... para que, um dia, numa agonia de saudade... É necessário ser-se reticencioso, ao escrever certas coisas, Pedro. Você precipitou, florista. Deixou que sua boca falasse antes do seu coração. E agora? É deixar a moça ir. Você já sabe onde ela está e ela lhe mandou dizer que se sente feliz. Portanto, não adianta a polícia. De nada servirão seu nome e o dela no Livro de Ocorrências. De nada. Para nada. Mande-lhe flores, com um recado (mesmo de mentira) que está feliz. Isso sim fica-lhe bem. Não adianta ser o mendigo de sensações impossíveis. Vá sua vida, pelos bares, pelas boates, como se nada houvesse mudado. Uma flor, um sorriso, uma frase de carinho para todos os namorados. Não deixe que ninguém descubra, em seu ar revelador, o grande sonâmbulo da noite. Porque os namorados e as flores não têm nada a ver com isso continuarão. E você não tem outra coisa a fazer senão continuar. Obrigado por este capítulo do "romance". Perdão pela indiscrição de escrevê-lo. Em sua homenagem, porém, os outros casos, muito mais policiais que o seu, ficarão para ser contados amanhã. Coragem, Pedro.

\section{NOTA NECESSÁRIA}

Na tarde de ontem, começou a constar no Livro de Ocorrências do $2^{\circ}$ DP o comparecimento de Pedro das Flores, que recorria à polícia de Copacabana para que fosse localizada sua ex-mulher. As diligências tiveram êxito, mas a pessoa procurada, além de negar-se a voltar ao seu ex-companheiro, exibiu a carta assinada pelo queixoso, onde havia uma espécie de atestado liberatório, documento dos mais ricos e originais até agora encontrados por este repórter.

A conhecida estratégia de Maria em se expor, como sempre se desqualificando, desemboca na criação de um importante personagem na galeria do "Romance": ele mesmo. O autor, que aqui aparece como "um repórter tresnoitado, sem tranquilidade de tempo e sossego", é o mediador dessa realidade. No caso de Pedro das Flores, que recebe um conselho amoroso do repórter, há primeiro uma narrativa melancólica e, em seguida, o ressurgimento da função jornalística, que retoma a linguagem objetiva. "Necessária" 
até no nome, a nota emprega expressões burocráticas em tom de distanciamento, fazendo com que a singela história se encaixe na crueza da vida real.

Talvez para não abandonar o ofício de cronista, Maria assume uma segunda coluna na Última Hora, paralela ao "Romance policial de Copacabana", por nome de "O jornal de Antônio Maria”. Determinar com precisão a data de estreia é difícil: até dezembro de 1960, o jornal circulava em duas seções, uma delas menor, em formato de tabloide. No início do mês, as tiragens são reajustadas e a publicação passa a ser única, em dois cadernos. O editorial de 7/12/1960 comenta que o conteúdo do antigo tabloide foi incorporado no segundo caderno, onde estavam "algumas das mais famosas colunas de $U H$, tais como 'O jornal de Antônio Maria', um dos pontos mais altos do colunismo nacional".

$\mathrm{O}$ arquivo do tabloide, onde Maria era publicado diariamente desde pelo menos junho de 1960, se perdeu. Não consta no acervo digital da Biblioteca Nacional. Do que se preservou, é possível constatar que embora a coluna represente um avanço no sentido literário em relação à "Mesa de pista", quase todo o interesse de Antônio Maria estava voltado para o "Romance policial de Copacabana". Com pesos diferentes, Maria empenha o repórter e o cronista na Última Hora até agosto de 1961, quando é demitido. O motivo: um relacionamento com Danuza Leão, esposa de Samuel Wainer.

\section{DANUZA LEÃO: PAIXÃo IMPROVÁVEL}

Em 1960, Danuza Leão tinha 27 anos de idade e seis de casamento com Samuel Wainer, pai de seus três filhos. Em Quase tudo, suas memórias, conta que a ausência do marido, consumido por questões do incerto cenário político do país, passou a incomodá-la. Para contornar a solidão, aguardava-o em companhia de amigos nas boates. As mesmas que Antônio Maria frequentava. A jornalista já o conhecia das rodas noturnas. Ela menciona sua personalidade exuberante, mas se impressiona mesmo com sua sensibilidade e com a disposição para ouvir:

Qualquer problema meu, fosse minha insatisfação com a babá dos meus filhos, fosse uma rusga com meu pai, ele tinha todo o tempo do mundo não só para escutar como para discutir, sugerir, às vezes aconselhar. Era 
exatamente o que eu não tinha de Samuel, era exatamente do que eu precisava - e Antônio Maria sacou. (2005, p. 83)

Antônio Maria tinha muitos casos extraconjugais. A necessidade da conquista aparece com frequência em sua biografia. Os amigos, muitos com inclinação ao papel do cafajeste sedutor, disputavam as namoradas. Era um comportamento comum entre os grupos das boates. Embora Maria fosse casado com Mariinha, pouco aparecia em casa, na rua Marquês de São Vicente, na Gávea. Sua residência era o Hotel Plaza. Em suas crônicas, os amantes aparecem muito. E junto deles, a traição, o ciúme, a paixão. Entre a crônica amorosa de Maria e o universo lírico de Vinicius de Moraes, seu amigo fundamental e grande protagonista desse modo de vida inconsequente, há muitos pontos comuns. Ambos fazem parte de uma mesma linhagem de artistas que abordaram o universo feminino com um desejo explícito de conquista, tanto na música quanto na literatura. Na vida de Vinicius, isso se manifestou sobretudo em seus nove casamentos - à primeira vista, uma busca avassaladora pelo amor e uma recusa à solidão. No caso de Maria, os movimentos eram menos decisivos. Teve casos que superaram a noite, como o da atriz Yolanda Cardoso e o da secretária Ligia Andrade. Com ambas, em momentos distintos, chegou a dividir apartamento. Mas nunca tinha desfeito o casamento com Mariinha. Diferente de Vinicius, não atravessava determinada linha - até se aproximar de Danuza Leão.

O interesse por Danuza, portanto, não seria inesperado. Mas que a ex-modelo tenha considerado Antônio Maria para ocupar a ausência que sentia, sim. Em suas palavras, ele, com quase quarenta, "não ostentava propriamente o físico de um galã: mulato de pele clara, era gordo, muito gordo, e de bonito não tinha nada" (p. 83), "não tinha as características de um homme du monde, que eu tanto apreciava" (p. 84) e "não correspondia a nenhuma das minhas fantasias em relação aos homens" (p. 84). Mas "tinha todo o tempo do mundo para mim" (p. 83).

Foi uma lacuna que os conectou. O episódio é simbólico, evoca muitos movimentos da vida de Maria, constatados também em sua carreira profissional: a ambição da conquista rápida, a disposição em assumir mais do que conseguia cumprir, a irregularidade das medidas. De certo modo, a vontade de viver um relacionamento 
duradouro com a esposa de seu patrão foi mais um deslocamento em sua biografia, mesmo que à primeira vista positivo.

Sem impor dificuldades, Samuel Wainer solicitou um acordo típico da classe burguesa: que a separação acontecesse somente após o evento de aniversário de seu jornal, em junho de 1961, dali a seis meses. Durante o período de espera, Antônio Maria compôs duas canções em parceria com Moacyr Silva, gravadas por Elizeth Cardoso: "Vem hoje" - "Faz falta em meu olhar o teu olhar/ A doce paz dos teus olhos/ Faz falta em minha vida/ O imenso bem do teu amor/ Vem sem medo, meu amor/ Meu caminho é fácil de encontrar" - e "Os teus encantos" - "Esse teu olhar/ Mudou a luz do meu olhar/ Esse teu andar/ Pra lá, pra cá/ Aonde irá me levar?”.

Os vaivéns amorosos ocupam espaço central na obra de Maria. Quase todas as suas composições musicais, cerca de sessenta, falam de relacionamentos. Das crônicas editadas, as mais famosas são sobre o amor - talvez por abordá-lo tão de perto, partindo de um ponto de intensa exposição. Antônio Maria é o mais exposto dos cronistas e não exclui questões negativas dos relacionamentos. Também abriga em sua prosa os conflitos e as violências, como se percebe no trecho de "Notas da chuva", de 12/3/1957:

Nenhuma emoção é mais forte que a de entrar no quarto da mulher que dorme. Sentir-lhe o cheiro e o calor, no ar do quarto. Tocar-lhe a pele poderosa. Nela, encontrar intensificação completa. Depois, dormir como na morte, para despertar ao peso dos deveres aflitos a cumprir. Um mistério indecifrável de uma mulher a que se volta. Só se ama uma mulher quando lhe tememos a pele e o cheiro. Quando a ideia de sabêla em outro amor nos torna capazes de matá-la ou perdoá-la. Matá-la e perdoá-la são duas coragens difíceis. Fica-se, geralmente...

Ama-se, angustiadamente, o vestido pendurado da amante ausente. E haverá mais verdade na companhia desse vestido (morto como um vestido) que adiante, nos braços de uma nova mulher.

Os sentimentos das nossas constantes paixões! Enlevo, carinho, generosidade, sacrifício. Infelizmente, por mais que se tenha feito para negá-lo, o verdadeiro amor é aquele que nos abrange e nos vence como 
um vício. Nunca se diga que o amor é fácil, antes de se vivê-lo como um vício.

O homem investe demais contra os seus gostos verdadeiros. Quando devia deixar-se de ser, consentir a si mesmo, procurar-se mais e mais no fundo de suas tendências.

A carne não mente. Apesar da má companhia em que vive, ainda não chegou à perfeição desse erro. Vivamos antes das palavras. Ou em vez das palavras. Seremos livres e intensos. [...] (MARIA, 1994, pp. 8182)

O "amor como vício" resume todo o olhar lírico de Antônio Maria. Não se espera comedimento de viciados. A disposição de encontrar na amada a "intensificação completa" e a busca pela vivência integral das "constantes paixões" dão margem para um comportamento ruidoso, agressivo. A noção de posse, embora nem sempre apareça às claras, é onipresente. Seu maior sintoma é o resguardamento do amor em ambientes fechados. Nas crônicas de Maria, os relacionamentos acontecem dentro do quarto. Quase não aparecem em espaços públicos ou na presença de terceiros.

Em junho de 1961, cumprido o acordo entre Samuel e Danuza, acontece o desquite. Para não perder a guarda dos filhos, porém, ela não poderia compartilhar o teto com outro homem. À essa altura divorciado de sua esposa, Maria aluga uma casa na rua Vitor Maurtua, na Lagoa. Para viver a nova paixão, perdeu o emprego, mudou de casa e abdicou da boemia.

\section{DIÁRIO DA NOITE: CRONISTA SOLAR}

A demissão do cronista certamente teve um impacto grande em sua vida profissional. Samuel Wainer era influente e poderoso. Pela primeira vez desde o estabelecimento no Rio de Janeiro, Maria precisou procurar emprego. Pediu abrigo a Assis Chateaubriand, seu primeiro patrão. Os Diários Associados, no entanto, já não gozavam do prestígio de antes. Em declínio de popularidade, várias publicações tiveram as tiragens reduzidas. $\mathrm{O}$ Diário da Noite, por exemplo, onde Maria passa a publicar a partir de setembro de 1961, circulava somente com 10 mil exemplares, contra os 350 mil da Última Hora. ${ }^{38}$ Assim,

\footnotetext{
${ }^{38}$ Segundo verbete "Última Hora" do Centro de Pesquisa e Documentação de História Contemporânea do Brasil (CPDOC) da Fundação Getúlio Vargas, de autoria de Carlos Eduardo Leal.
} 
do dia para a noite, Maria perde 340 mil leitores. Em nome de uma paixão deslocada, a popularidade reduzida foi o primeiro dos golpes que o cronista sofreu no fim da vida.

Apesar da decadência, o jornal tinha nomes fortes, como Sérgio Porto e Nelson Rodrigues. Lá, Maria é bem alocado, com destaque visual. Quase sempre a coluna ocupa toda a página. Esse é o período mais solar de sua vida - consequência, certamente, de uma paixão improvável. Sua crônica, treinada na escola da noite, ajusta o relógio para o dia. Em tom iluminado, aparecem passarinhos e namorados. Uma revigorada energia vital pulsa até quando fala de política, insistentemente criticando Jânio Quadros, que tinha acabado de renunciar à presidência da República.

Durante todo o período do Diário da Noite, Maria está em paz. Declarações de felicidade não são raras: "Eu sou, modéstia à parte, e com licença da palavra, feliz" (9/12/1961). Longe dos amigos e da vida social, o cronista identifica o novo momento de vida como o início da velhice: "Há muito tempo não passava pela avenida Atlântica, à uma da madrugada. Depois de velho, resolvi fazer uma nova vida e fiz sem querer uma vida tão antiga que nunca mais botei o pé na rua depois das dez da noite" (9/11/1961).

O amor segue sendo tratado em recolhimento, mas da perspectiva do vitorioso, não mais com o sentimento de frustração. Uma pequena crônica de nome "Legenda", inédita em livro e publicada em 29/11/1961, evoca um cenário etéreo para um casal apaixonado:

Subamos a montanha, para mais alto. Tão alto que não nos possam mais chamar. Tão alto que nos esqueçam. Tão alto que eu veja a lagoa do tamanho de um orvalho. Tão alto que, lá embaixo, o presente se perca aos olhos e se transforme numa lembrança imprecisa. Tão alto que o passado fique, de repente, incerto e impresumível, como o futuro. Tão alto que possamos ver e sentir as primeiras luzes e as primeiras paredes do futuro. Chegar ao futuro de madrugada, pela primeira vez, como a uma branca cidade adormecida.

Quero estar tão perto de ti que eu não te veja. Tão perto, tão em ti, que eu te esqueça. É necessário que eu te esqueça um dia, que eu te perca um dia, dentro dos meus braços. E que me esqueças, por eu te pertencer, como uma camisa. Tu e eu. Eu sem mim. Tu sem ti. Ambos despertos, mas sem ser, sem ter, sem estar. Tu e eu, equidistantes do desejo e da 
saciedade. Tu e eu, durante... e o tempo sem som, desincumbido de nós.

Seremos tão sós que esquecerás o meu nome e eu esquecerei o teu. Para que é preciso ter um nome? Para saber, afinal, quem sofreu mais? Quem ganhou, quem perdeu? Quem irá merecer o milagre ou o castigo? Estaremos tão alto, tão unidos, tão sós, tão insubsistentes mesmo que os nossos corpos, sem fronteiras, dormirão do mesmo sossego, da mesma fadiga, do mesmo silêncio.

A declaração é de algo que se quer extraordinário. O amor cresce com a dissolução dos elementos primordiais da realidade - o espaço, "tão alto", é surreal; e o tempo, "incerto e impresumível”, impossível. Presente, passado e futuro se tornam adereços, detalhes de uma nova organização de mundo que tem, como eixo definidor, a união dos indivíduos. Tudo é descolado de sua definição lógica, e as ideias opostas se aproximam, como se buscassem um sentido oculto das sensações. O paradoxo de estar perto de alguém e não vê-lo quer alcançar uma disposição essencial, de algum modo primitiva, dos sentimentos. A fusão de dois sujeitos pressupõe a desagregação das individualidades, "sem fronteiras", o que costuma resultar em conflitos e enfrentamentos. $\mathrm{O}$ amor para Antônio Maria está ligado ao atrito. Por isso fala em ganhar e perder, em merecimento e castigo, ainda que durmam "do mesmo sossego".

O período de franca alegria dura até fevereiro de 1962, quando, acometido por dívidas, o Diário da Noite deixa de circular. As colunas são absorvidas pelo veículo remanescente dos Diários Associados, O Jornal. Realocado, o cronista retorna ao primeiro espaço que o acolheu quando chegou ao Rio de Janeiro, catorze anos atrás.

\section{O JORNAL: DE GOLPE EM GOLPE}

Em O Jornal, que também não vivia um bom momento, Maria perde o destaque visual. Com uma diagramação conservadora, "O jornal de Antônio Maria" ocupa somente um quarto de página. Nesse período, o cronista dá mais espaço à seção "Fac-símile", que criou ainda no Diário da Noite e rebatizou muitas vezes, até se estabelecer como “Romance dos pequenos anúncios". São breves exercícios de ficção, geralmente esquetes de humor, que se desdobram a partir dos classificados comerciais. Essa ressignificação de gêneros jornalísticos por uma abordagem inventiva é algo que o cronista soube praticar 
com muita originalidade. Provavelmente, pelo corte rápido e a linguagem breve, os textos se assemelham aos que escrevia para a televisão.

É dessa fase uma notável sequência de crônicas memorialísticas, algumas analisadas anteriormente. São belos momentos da infância pernambucana em que o cronista identifica no passado as inquietações do presente. Diferente do que costuma se afirmar nas produções sobre Antônio Maria, o cronista preparava, enfim, um livro. A confirmação aparece em uma nota publicada no rodapé de uma das crônicas sobre Recife:

Meu prezado José Olympio: É esta a segunda crônica de uma série sobre o trem. A terceira será publicada na segunda-feira, amanhã, n'O Cruzeiro. São notas memorialísticas que sei que só deveriam ser grafadas daqui a uns vinte anos. Mas tenho uma dívida para com você. O dinheiro que você me adiantou por um livro que jamais escrevi. A princípio, por falta de assunto. Depois, por idiossincrasia às noites de autógrafos. Você não sabe, José Olympio, que tortura para um homem de caráter o sujeitar-se a uma noite de autógrafos. O ver os rostos milenares do "eterno livro brasileiro". Mas, meu prezado José Olympio, a não ser que você aceite a devolução do capital que jogou às minhas patas, vou entregar-lhe um livro. Não sei quando, mas um livro sério. Sério como sempre fui, a não ser na transação equívoca com você. Meu prezado editor, prometa não me sujeitar a uma noite de autógrafos e, dentro de muito pouco tempo, o João Condé ${ }^{39}$ lhe levará os originais. Seu admirador, o AM. $(24 / 6 / 1962)$

Ao puxar o fio da memória, o cronista preparava o que dispunha de melhor, aguçando seu sentido literário. Já tinha feito movimento semelhante em 1953, na Manchete, quando se deu conta do valor de suas lembranças. Se seria mais um esforço vão, impossível saber. Pode ser que, com medo do julgamento alheio, desistisse outra vez de publicar. De todo modo, é certo que estava disposto a concluir a conversa com José Olympio que já durava cinco anos, conforme registro em seu diário de 1957:

João Condé animou-me a publicar um livro de crônicas. José Olympio o editaria. Pela primeira vez animei-me a selecionar velhas crônicas. Mas terei que reescrevê-las. Não suporto ler o que escrevi há uma

\footnotetext{
${ }^{39}$ Condé era o responsável pela coluna "Arquivos implacáveis", publicada por dezenove anos na revista $O$ Cruzeiro. Dedicava-se aos bastidores do mundo da literatura. Como colecionador, recebia originais, manuscritos e fotos de diversos escritores e aspirantes. Tornou-se uma espécie de depositário literário.
} 
semana. Sou preguiçoso e, por isso, humilde. Certamente, esse livro ainda não será agora. (2002, p. 17)

A lacuna de Antônio Maria no catálogo da José Olympio causa estranheza. Mas sua ausência na Editora do Autor é ainda mais espantosa. Fundada e dirigida por Rubem Braga e Fernando Sabino, amigos que elogiavam seu texto, a casa editou com sucesso de vendas todos os grandes cronistas da época, encerrando antigas dúvidas e pequenas polêmicas em torno da compilação de livros do gênero.

Anos antes, em março de 1956, a imprensa noticiou discretamente a publicação de Vento vadio, uma antologia de crônicas de Antônio Maria pela editora Alvorada, de Lúcio Rangel, Paulo Mendes Campos e Irineu Garcia. A Alvorada, tomando o nome ao pé da letra, durou pouco: o único livro publicado foi Flauta de papel, com crônicas de Manuel Bandeira e capa de Carlos Drummond de Andrade, em 1957. O anúncio do compilado de Maria consta na seção de publicações futuras, na última página do livro. Embora tivesse divulgado na imprensa um catálogo encorpado, é provável que a editora tenha se dissolvido numa mesa de bar, junto ao gelo do uísque, do mesmo modo que surgiu. ${ }^{40}$

\footnotetext{
${ }^{40}$ Notas espalhadas prometem um catálogo nunca realizado: Poesias completas, de Vinicius de Moraes, Lições de um ignorante, de Vão Gogo (pseudônimo de Millôr Fernandes), Subterrâneos do Rio de Janeiro, de Sérgio Porto, uma antologia de Rubem Braga e História literária do diabo, de Luis Santa Cruz. O escritório da editora ficava na avenida Franklin Roosevelt, 84, no Centro do Rio.
} 
Estivesse ou não finalmente encarando a sério a possibilidade de publicação, Maria menciona a continuidade da série memorialística em $O$ Cruzeiro. Assim como os outros títulos do grupo de Chateaubriand, a revista vivia um período de declínio, com a tiragem reduzida de 710 para 400 mil exemplares. Lá, publica a coluna "Sete dias" de maio a agosto de 1962, em apenas dezesseis edições. Como as outras experiências em revista, é um momento inspirado. Curioso apontar que esse é o único período em que os títulos de suas colunas não aludem ao universo noturno. "Sete dias" e "O jornal de Antônio Maria", em oposição a "A noite é grande", "Pernoite", "Plantão noturno" e "Mesa de pista", não têm compromisso com a noite.

Obeso, fumante e sobrecarregado de trabalho,

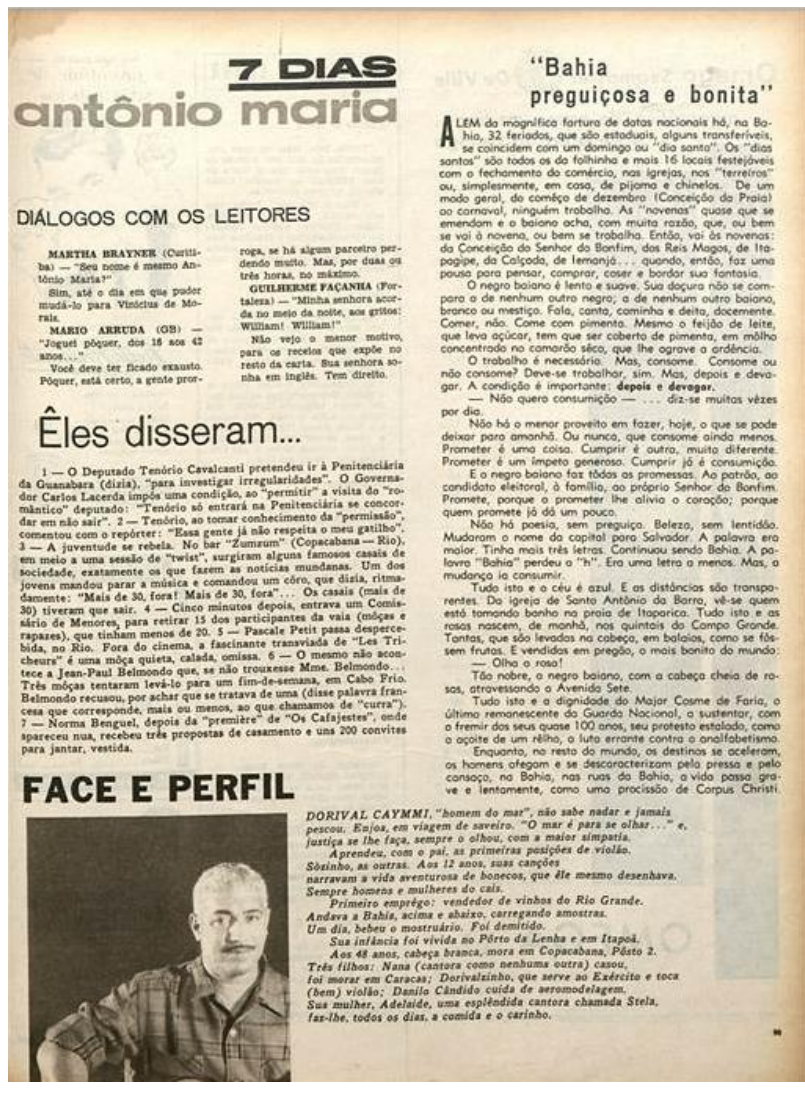
Maria sofre um infarto em novembro de 1962. É o segundo dos golpes violentos que balançam os anos finais. Na manhã do dia 29, é internado na Casa de Saúde Dr. Eiras, sob os cuidados do médico Paulo Niemeyer. Fica no apartamento B do primeiro andar até receber alta, no começo de dezembro. Somente em 14/12 retoma a colaboração com o jornal, e em ritmo lento - as várias seções de "O jornal de Antônio Maria" deixam de existir, e o espaço, que dura até o fim do ano, é rebatizado de "Algumas crônicas".

Todas inéditas, essas crônicas são considerações de um observador enfermo, recolhido em casa. Mas a casa em questão já não era somente sua. Para ajudar na recuperação de Maria, Danuza Leão descumpre o acordo com Samuel Wainer de não coabitar com o companheiro:

As crianças iam entrar de férias, e, como iam passá-las com Samuel, levei Antônio Maria para minha casa; alugamos uma cama de hospital, já que ele deveria permanecer deitado. Maria deixou de fumar - eram três maços por dia - e passou a comer coisas leves e sem sal. [...] De uma hora para outra tudo mudou, e a alimentação passou a ser frango e legumes cozidos. Eu desempenhava o papel de enfermeira; ficava o dia inteiro levantando e abaixando a cabeceira e os pés da cama, fazia a barba dele, dava banho e, por solidariedade, seguia a mesma dieta. [...] 
Quando chegou o Natal, constatei que a vida ia ficar muito difícil com as limitações que a doença havia trazido a Maria, e resolvi enfrentar Samuel. Disse que, quando acabassem as férias, eu ia morar com Antônio Maria na casa dele [...]. Para meu grande espanto, Samuel não criou caso, e em março de 64 nos instalamos na casa de Maria, no Jardim Botânico. (LEÃO, 2005, p. 90)

A proximidade, porém, fez com que a relação piorasse. Rompantes violentos de ciúme desmedido eram frequentes. Danuza Leão queixa-se que Maria, possessivo, se altercava com homens virtuais do recinto - o cantor do rádio, o apresentador de televisão e até seu próprio reflexo no espelho. Ele parece ter se dado conta que a ambição tinha sido demasiada; e ela, que estava presa a um homem cuja saúde debilitada poderia não aguentar um término definitivo.

O golpe militar, em março de 1964, vem acirrar os problemas de ordem pessoal e conjugal. Com a deposição do presidente João Goulart e a eleição indireta dos militares, Samuel Wainer busca refúgio na embaixada do Chile. O Última Hora era um dos poucos jornais que apoiavam Jango. Em segredo, Danuza e Samuel se encontram para combinar a guarda dos filhos. Temendo a retaliação ideológica, ele planejava sair do Brasil. O encontro dos dois teria sido o estopim do relacionamento conflituoso com Maria, que some por alguns dias. Ela, com medo, viaja para Paris, e os dois nunca mais se veem.

A separação, transformada em fardo, é o terceiro e mais difícil golpe que sofre. Desolado e deprimido, Maria some também do jornal. Reaparece na semana seguinte, mas fica só até o fim de abril, quando se ausenta por um período de três meses. O tom solar que marcou os anos anteriores desaparece. A tristeza e a melancolia tomam conta de suas crônicas. Nesses dias de abril, aborda algumas vezes a ruptura política e a tomada de poder pelos militares.

Como a maioria dos colunistas, Maria não fala em golpe - nem poderia, escrevendo em um veículo conservador como O Jornal. Atraído pelo perfil comedido do marechal Castello Branco, o primeiro presidente da ditadura, cuja "figura moderada e ambígua tornou-o uma excentricidade na trajetória do regime que ajudou a fundar" (GASPARI, 2002, p. 230), acredita que o militar poria fim às instabilidades políticas.

O discurso inicial é de combate à corrupção, o que atrai desiludidos com os vaivéns dos governos anteriores - Maria desprezava Jânio Quadros, João Goulart, Carlos 
Lacerda e muitos outros "políticos tradicionais". Nos anos seguintes, enfrentar a corrupção deixaria de ser uma bandeira de Castello Branco, já que as auditorias chegavam não só a congressistas da base aliada como a figuras importantes do próprio governo em 1966, descobriu-se que Romero Lago, chefe do departamento de censura, era um estelionatário foragido que deixara para trás seu nome verdadeiro. ${ }^{41}$

Nada disso estava claro no momento do golpe, nem para a maioria da população, nem para Antônio Maria, que acreditava na boa condução do marechal se empenhasse valores democráticos - os mesmos que o regime militar aboliu conforme criou ferramentas autoritárias para se perpetuar no poder.

Embora com um "desde que", uma notícia animadora nos jornais: "Revolução garante a liberdade de imprensa". Isto quer dizer que, passados os primeiros momentos, já se pode voltar a escrever sobre o que não está certo, inclusive que, no delírio da ira, foram cometidos alguns excessos de "justiça". Por exemplo, algumas pessoas que não tinham nada a ver com o comunismo, e que jamais simpatizaram (sequer simpatizaram) com o governo deposto, foram presas ou ameaçadas. Logo ao anoitecer de $1^{\circ}$ de abril, a denúncia pura e simples era o bastante para que uma turma do DOPS entrasse lares adentro, vasculhasse tudo e levasse o dono da casa, com a alegação de que foi encontrado "vasto material subversivo". Esse "vasto material subversivo" era, muitas vezes, as Memórias do cárcere, de Graciliano Ramos, ou Ascensão e queda do III Reich. Ora, qualquer pessoa alfabetizada lê, e se lê, é claro que não tenha lido apenas Em cima da hora, de Suzanne Labin. ${ }^{42}$ Os jornalistas recebem todos os livros editados no Brasil e é natural que suas estantes estejam repletas daquilo que, na opinião do coronel Borges, pode ser chamado de "vasto material subversivo". [...] Agora, a gente já pode escrever essas coisas, porque graças a Deus a "revolução garante a liberdade de imprensa" e estou certo de que os jornalistas livres, que se nunca tiveram compromissos com a bolchevização do Brasil, não os terão jamais com os erros e

\footnotetext{
${ }^{41}$ Sobre o episódio do censor, conferir OLIVEIRA, José Carlos. Diário da patetocracia. Rio de Janeiro: Graphia, 1995 e GASPARI, Elio. A ditadura envergonhada. São Paulo: Companhia das Letras, 2002.

${ }^{42}$ Cientista política anticomunista. O livro citado, sobre as estratégias de comunicação da União Soviética, foi traduzido por Carlos Lacerda.
} 
excessos praticados em nome da pátria e da democracia. (MARIA, $15 / 4 / 1964)$

$\mathrm{Na}$ mesma coluna, ao apontar arbitrariedades violentas, diz que "muita gente se aproveitou da revolução para vingar-se de seus desafetos", denunciando como comunista quem quer que se desgostasse. Para que se enxugue as lágrimas de "mulheres e crianças que, da noite para o dia, ficaram sem hoje e sem amanhã”, pede a revisão imediata dos detidos: "É urgente que se reparem as iniquidades cometidas contra chefes de família. Está certo, a revolução, segundo se propala, evitou derramamento de sangue, mas de lágrimas não. Sim, meu prezado Presidente da República, é preciso evitar derramamento de lágrimas".

Castello Branco era representante da dita "linha branda". Ao lado do general Golbery, chefe do SNI, o Serviço Nacional de Informações, órgão ideológico que difundia propaganda e coletava delações, procurava "assegurar a liberdade de expressão, respeitando a imprensa estabelecida e as manifestações culturais" (GASPARI, 2002, p. 237). Mas os protestos, sobretudo de estudantes, estimulavam militares da "linha dura" a disputar o poder internamente. Fazia parte da narrativa de Castello Branco uma atuação pública de benevolência:

Castello lutava para desembaraçar-se do risco da ditadura por meio dos mais diversos recursos. Para espanar a pátina de irracionalismo que lhe cobria o governo, mostrava-se homem de cultura. Almoçava no palácio Laranjeiras com o poeta Manuel Bandeira, ia às peças de teatro de Tônia Carrero, frequentava as chatas sessões de posse na Academia Brasileira de Letras. Era capaz de lances de refinada elegância, como o de aparecer num concerto da Orquestra Sinfônica de Londres, regida por sir John Barbirolli, um ex-combatente da Segunda Guerra, levando consigo seu comandante na Força Expedicionária Brasileira, marechal Mascarenhas de Moraes, e instalando-se numa modesta frisa em vez de ocupar o camarote presidencial. (GASPARI, 2002, pp. 229-30)

Antônio Maria acreditava em Castello Branco. Mais do que isso, achava que os militares assegurariam o regime democrático, em oposição à falsa e tão alardeada ditadura que João Goulart e os comunistas instalariam no Brasil:

Mas, agora, as coisas vão entrar nos eixos. O general Castello Branco tomará posse hoje e suas promessas são de paz e justiça. A revolução 
deixará de pertencer apenas a Copacabana, às pessoas que moram em apartamentos de quatro quartos e duas salas para ser uma revolução do povo. As reformas terão que ser feitas e, como diz o deputado João Calmon, em tempo recorde. As eleições de 65 terão que ser realizadas livremente, sem "desde que", para que o povo eleja não apenas Ademar de Barros, Carlos Lacerda e um outro candidato que nascerá da revolução, mas também o "comunista" Juscelino, como foi chamado em palavras escritas e faladas, quando a insurreição de $1^{\circ}$ de abril pertencia apenas a Copacabana e, especialmente, ao Posto Seis. (MARIA, 15/4/1964)

Não foi o único artista e intelectual a reagir assim. Diante dos valores empenhados nas crônicas de abril, é possível imaginar que, se tivesse vivido para ver, teria percebido o equívoco em juntar harmoniosamente as palavras "general" e "democracia" na mesma frase. É difícil imaginar um contestador como Antônio Maria assentado em uma ideia que não custou a se revelar falsa. Seu espírito não estava tranquilo: "O que estaria acontecendo aos vencidos? Como estariam se portando os vencedores? Por compaixão e cuidado, em meio a uma sensação de profundo desgosto, os dois bandos me preocupavam” (MARIA, 10/4/1964).

Escrever sobre o golpe foi uma distração pessoal. Para ele, mais impactante do que a política brasileira era o fim do relacionamento com Danuza Leão. Deprimido, volta a morar em Copacabana, num apartamento mobiliado na rua Fernando Mendes. Atravessa um período de amargura distante de trabalhos criativos. Só no final de julho consegue retomar a coluna no jornal, num momento em que se entrevê um facho de luz: "Com vocês, por mais incrível que pareça, Antônio Maria, brasileiro, 43 anos, cardisplicente (isto é: homem que desdenha do próprio coração). Profissão: Esperança” (23/7/1964).

Pelo balanço de temas é possível medir a luta do cronista pela retomada da vida. Ora mais para lá, escrevendo sobre morte e solidão, ora mais para cá, evocando episódios sociais com ar de gratuidade, como em "A ressaca", de 12/8/1964:

Está sendo difícil pra mim sair da cama. Muito. Acontece que ontem houve reunião em casa de amigos e, como fazia frio, bebi. Se não fizesse frio, beberia também, porque era "Dia do papai", consequentemente, meu dia, no que diz respeito não só a Maria Rita e Antônio Filho mas a todos os órfãos permanentes e temporários da vida. Bebi e, já que estava 
bebendo, dei cabo de uma garrafa. Aqui está Antônio, na cama, sem a menor possibilidade de levantar-se, escrevendo essas notas por conta de suas obrigações com Assis Chateaubriand e João Calmon.

O que é a ressaca? Na maioria dos homens o dia seguinte de um pileque e dor de cabeça, boca amarga, pés inchados. Em mim, nada dói. A ressaca é simplesmente um profundo estado de culpa. Todas as culpas caem sobre mim, desde as primeiras. Sinto-me culpado, por exemplo, de ter enfeiado o corpo de minha mãe, durante os meses em que fui gestado. De ter-lhe causado as dores das vésperas e a dor sublime de 17 de março de 1921. Fui a criança que mais doeu na família. Pobre dona Diva! E continuei doendo. E "douo" ainda hoje, por viver tão exposto às mortes da vida.

Esperanças, Diva! Daqui pra frente, embora não me sinta capaz de evitar-me os desvarios, evitarei ao máximo que eles lhe atinjam. Aqui estou eu, sem coragem para um só gesto. José Aparecido telefona e se queixa da minha influência nefasta em sua vida pós-revolução. [...] Em dia de ressaca, aceito e assumo todas as culpas que me impõem. Sim, sou eu o culpado de todos os males [...].

E continuo sem poder levantar-me. Sem querer também. O homem de caráter é aquele que, mesmo podendo, não deseja levantar-se. Eu tenho muito caráter. Hoje, irei encontrar uma moça clara. Pelo meu gosto não iria. Tenho medo dela e de mim, também. Tenho medo de tudo quanto é mulher... e de mim, também. Sabe como é: no começo, tudo são flores. Depois, a gente gosta, vem os ciúmes... e adeus sossego. Vou encontrar uma moça clara e, com franqueza, preferia que ela fosse escura. Ou melhor: que ela não fosse. Mas, ela irá, eu direi o de sempre e acontecerá o de sempre. Riso, amor e perdição. Rir, rir, rir! Pobre moça! Pobre Maria! Mas que seja tudo por um Brasil melhor.

Edith, minha cozinheira e diretora espiritual, trouxe a oração mais eficaz da Devoção a Santo Antônio. Chama-se "Cinco minutos diante de Santo Antônio" e começa nas disposições do meu padroeiro em relação a mim: "Sinto-me disposto a fazer tudo por ti, mas, filho, dizeme uma a uma todas as tuas necessidades".

Quero pouca coisa, meu padroeiro. Um pouquinho de dinheiro, para jantar com vinho, todas as noites, aqui no Bistrô. Coisa pouca. Uns 40 
ou 50 contos para jantar com vinho. Queria, ainda, que o Walter Clark não me tratasse tão mal, preterindo-me, acintosamente, por amor a Nelson Rodrigues. Acho que é só, Santo Antônio. Saúde para dona Diva e para meus filhos. Os outros, todos os outros, já têm quem reze por eles.

Ah, sim. Ia esquecendo. Vê se melhora o bico de papagaio do José Aparecido. Melhorar. Curar, não precisa. No mais, que me passe essa ressaca. É só, Santo Antônio. Até amanhã.

O movimento do cronista superando a depressão é nítido: em tom descontraído, fala da reunião com amigos, de encontros amorosos com mulheres. Mas, como todos, o processo de recuperação é lento. Para cada crônica amena há uma porção de amarguradas. A morte é um elemento constante, como em "Canção de homens e mulheres lamentáveis": "Há poucos minutos, em meu quarto, na mais completa escuridão, a carência era tanta que tive de escolher entre morrer e escrever estas coisas. Qualquer das escolhas seria desprezível" $(9 / 10 / 1964)$.

Alguns dias depois, na madrugada de 15 de outubro, Maria sofre outro infarto. Tinha trocado um cheque no bar e restaurante Le Rond Point, em Copacabana, quando rodopiou, caiu e bateu a cabeça na calçada. Chegou a ser socorrido pelo comissário Nilo Raposo, que tentou levá-lo ao hospital Rocha Faria. Antônio Maria morreu no caminho, aos 43 anos, entre $2 \mathrm{~h} 30$ e $3 \mathrm{~h}$ - justamente na situação que mais procurou viver, de madrugada e na rua.

O sepultamento se deu no cemitério de São João Batista, em Botafogo, às 16h. A imprensa registra um grande acompanhamento de "sambistas da Velha Guarda, compositores da Bossa Nova, escritores, jornalistas, políticos e gente do show business". ${ }^{43}$ Não houve discurso nem solenidades.

Maria deixou pronta sua última crônica: "Uma velhinha", publicada no dia seguinte, é sobre uma senhora que sempre se torna o centro das atenções no restaurante

\footnotetext{
${ }^{43}$ Dentre os presentes, a reportagem destaca Almirante, Antônio Bandeira, Barão Von Stuckert, Benê Nunes, Blecaute, Bororó, Cauby Peixoto, Chacrinha, Ciro Monteiro, Dircinha Batista, Dorival Caymmi, Elizeth Cardoso, Emilinha Borba, Fernando Lobo, João Condé, João Saldanha, Luiz Bonfá, Millôr Fernandes, Murilinho de Almeida, Paulo Gracindo, Paulo Soledade, Reinaldo Dias Leme, Sacha Rubin, Sérgio Porto, Walter Clark, Ziraldo e o sobrinho de Vinicius de Moraes, representando o tio. Das coroas de flores institucionais, registra o restaurante Le Bistrô, a boate Sacha's, União Brasileira de Compositores, Rádio Mayrink Veiga, Organização Victor Costa, Rádio Jornal do Brasil, Irmãos Vitale, Churrascaria do Leme, TV Rio e $O$ Jornal. Mariinha, sua primeira esposa, também enviou uma coroa.
} 
que frequenta. Leva os próprios talheres e não abre mão de suas manias e gostos. "A velhinha, tão bela e frágil por fora, magrinha como ela é, se a gente abrir, vai ver tem um homem dentro. Um homem solitário, que sabe o que quer e não cede 'isso' de sua magnífica solidão".

Não passa despercebido que a palavra final de Antônio Maria tenha sido "solidão". A solidão foi o fantasma que rondou sua vida, o eixo de sua obra literária, o filtro de sua visão de mundo. Foi sua verdade íntima e o vazio que o consumiu por dentro. Descrente de si, nunca encarou como literatura o que escreveu. Esquivou-se do projeto do livro, compromisso sempre adiado e no fim desfeito por uma sequência de golpes árduos. Privou os leitores de um conjunto trabalhado de suas crônicas. Tinha consciência de sua imensa volubilidade mas tudo indica que, superada a fase de decisões ruins, encararia uma vez mais a ideia do livro. Não deu tempo. Assim, Vento vadio, título que chegou a pensar para uma antologia, se desfez no ar. Dispersas, as crônicas ainda precisam ser articuladas por perspectivas que procurei assinalar neste estudo. E uma vez estabelecida, a obra não realizada de Antônio Maria irá colocá-lo, para espanto do próprio, ao lado de nossos maiores cronistas. 


\section{Anexos}

\section{RELAÇÃO DE COLUNAS}

A tabela leva em conta somente colunas com periodicidade fixa, não colaborações esparsas. Os meses marcados com asterisco indicam imprecisão por falta de registros. Em quase todas as colunas há irregularidades de periodicidade que variam de semanas a meses. Esta sistematização não é definitiva. Existem ainda muitas revistas que não foram consultadas, seja por falta de tempo, no caso da Senhor, seja porque não estão disponíveis para acesso público.

\begin{tabular}{|c|l|l|l|}
\hline \multicolumn{1}{|c|}{ ANO } & \multicolumn{1}{|c|}{ PERÍODO } & \multicolumn{1}{c|}{ COLUNA } \\
\hline 1944 & Janeiro a março & Folha da Manhã (PE) & Irradiações \\
\hline $1946-1947$ & Janeiro* de 1946 a março* de 1947 & Cidade do Salvador (BA) & O comentário de Antônio Maria \\
\hline $1948-1952$ & Dezembro de 1948 a fevereiro de 1952 & O Jornal (RJ) & Rádio \\
\hline 1952 & Fevereiro a abril & O Jornal (RJ) & A noite é grande \\
\hline 1952 & Março a junho & Última Hora (RJ) & E passamos a apresentar! \\
\hline 1952 & Agosto a outubro & Comício (RJ) & A noite é grande \\
\hline $1952-1953$ & Novembro de 1952 a dezembro de 1953 & Manchete (RJ) & Pernoite \\
\hline $1953-1955$ & Fevereiro de 1953 a janeiro de 1955 & Diário Carioca (RJ) & A noite é grande \\
\hline 1954 & Janeiro a agosto & Revista da Semana (RJ) & Plantão noturno \\
\hline $1954-1959$ & Agosto de 1954 a junho de 1959 & O Globo (RJ) & Mesa de pista \\
\hline 1956 & Agosto a dezembro & O Semanário (RJ) & Dia e noite \\
\hline $1969-1961$ & Agosto de 1959 a agosto de 1961 & Última Hora (RJ) & Romance policial de Copacabana \\
\hline $1960-1961$ & Setembro* de 1960 a agosto de 1961 & Última Hora (RJ) & O jornal de Antônio Maria \\
\hline $1961-1962$ & Setembro de 1961 a fevereiro de 1962 & Diário da Noite (RJ) & O jornal de Antônio Maria \\
\hline 1962 & Maio a agosto & O Cruzeiro (RJ) & Sete dias \\
\hline $1962-1964$ & Março de 1962 a abril de 1964 & O Jornal (RJ) & O jornal de Antônio Maria \\
\hline 1964 & Julho a outubro & O Jornal (RJ) & O jornal de Antônio Maria \\
\hline
\end{tabular}




\section{PEQUENA ANTOLOGIA}

1. Eram cinco irmãos (publicada no jornal Última Hora em 26/10/1959, recolhida no livro O jornal de Antônio Maria)

Eram cinco irmãos, cinco pessoas muito unidas, numa família que vinha de avô muito bom e muito nobre. Acordavam de manhã cedinho, beijavam-se (os mais velhos ajudavam os menores a vestir-se), e sentavam a uma grande mesa de café. Comiam, fartamente, de bolos e de queijos especiais, além de aipins, batatas e inhames, entre goles volutuosos de um gordo, doce e quente café com leite. Depois chegava a professora de piano e, um a um, tomava a lição de todos. Na casa, subindo ao andar de cima (que parecia vazio, de tão grande), repetiam as notas do exercício: dó-mi-sol-ré-mi-ré-dó. Na rua, os primeiros pregões do cuscuzeiro, do vassoureiro e do homem de "lã-de-barriguda".

Lá pelas nove, os cinco irmãos tomavam banho, botavam-se a cheirar de lavanda inglesa e desciam para a lição de francês. A professora: uma mademoiselle de corpo grande e rosto feio. Os olhos e a boca sempre tristes e o nariz vermelho, de bolão. Seu vestido cheirava a roupa que se suava, se guardava, se vestia de novo e nunca era necessariamente lavada ou posta ao sol. E, se mademoiselle não tivesse muitos iguais, era sempre o mesmo - preto de meias mangas, uma gola branca passada a ferro, um cinto cinzento com fivela coberta de veludo (preto também), a saia justa nos quadris, indo até os tornozelos. Os sapatos, baixos, de verniz, com uma fivela de adorno, no peito do pé. Começava a aula com uma pergunta direta: Est-ce un livre? E o arguido respondia, fazendo o bico que lhe era recomendado para evitar a pronúncia norte-brasileira o mais possível e, naturalmente, facilitar a pronúncia francesa: Oui, c'est un livre. Depois, vinha a pergunta falsa. Mademoiselle apontava uma pilha de livros e perguntava: Est-ce que se sont des cahiers? E o arguido com ar vitorioso: Non, ce ne sont pas des cahiers. Ce sont des livres. E mademoiselle, rescendendo o seu vestido negro, ordenava o exercício mexendo a xícara do café, que lhe era trazido, religiosamente, ao meio da lição, por uma criada de avental muito limpo: Escrivez la leçon numéro deux au pluriel - c'est un homme, ce sont hommes etc.

Dos cinco irmãos, um morreu e os outros quatro ficaram pobres. Foram viver cada qual um destino malfadado, envelhecendo e engordando, simplesmente. Escrevem-se nas datas e, antigamente, para avisar o nascimento dos filhos. Não se veem, nem se mandam fotografias, que é para não serem comparados, como no tempo da lição de piano, da lição 
de francês, da casa, enfim, que hoje é um prédio banal de apartamentos, com farmácia, açougue e lavanderia, nas lojas térreas. Na rua, não há mais pregões e as manhãs dos domingos perderam aquele ar de imensa felicidade...

2. A mesa do café (publicada no jornal Diário da Noite em 26/9/1961, recolhida no livro O jornal de Antônio Maria)

Menino só sabe que é feio, no colégio, quando o padre escolhe os que vão ajudar à missa, os que vão sair de anjo, na procissão, e os que vão constituir a diretoria do Grêmio Mariano.

Eu soube que não era bonito em 1928, no Colégio Marista do Recife. Nunca fui escolhido. Mas sem a menor tristeza, sem concordar até. Aquele julgamento era precipitado, pois (estava convencido) ainda não havia nada de definitivo sobre o bonito e o feio, a beleza e a fealdade. Quais seriam as demarcações? Se não existia a explicação lógica do feio e do bonito, a notícia da minha feiúra não me causava mal nenhum. Ao contrário, livrava-me dos tributos que teria de pagar se fosse bonito, ajudando missa e saindo de anjo, à frente das procissões.

$\mathrm{Na}$ mesa do café, éramos cinco irmãos. Havia bolo de mandioca, requeijão, bananas fritas, pão torrado e bolacha d'água. Éramos cinco irmãos e, dos cinco, quatro eram bonitos. Vá lá, eu era o feio. Então, por que minha mãe gostava mais de mim? Ela, que nos zelava a todos, que nos conhecia pelo avesso e pelo direito, por que gostava mais de mim? De pena não era, porque pena é uma coisa e amor é outra. Menino conhece. $\mathrm{O}$ gesto complacente, por mais carinhoso, é sempre vacilante e triste. O gesto de amor chega a ser bruto, de tão livre, alegre e descuidado.

Minha mãe gostava mais de mim. Eu sabia, e ela sabia que eu sabia. Em tudo a nossa cumplicidade. $\mathrm{Na}$ fatia de bolo, na talhada de requeijão e no sobejo do seu copo d'água. Nossa cumplicidade até hoje existe, quando de raro em raro nos encontramos. Da mesa do café, víamos pela vidraça, os canteiros de terra negra e as rosas de maio. Vinha o cheiro úmido da terra molhada, mais que o das pálidas rosas da minha infância. Minha mãe e eu. Nossos olhos tão parecidos. Minha mãe só tem um defeito. Não ser minha filha. Sempre foi metida a saber mais que eu. 
Só soube que era feio, quando amei, pela primeira vez. Vi-me, então, corajosamente... e não era como gostaria de ser. No coração, um amor tão bonito. Ninguém iria acreditar, mesmo dizendo, mesmo eu explicando, mesmo eu jurando.

Apaguei a luz, tocava o concerto $\mathrm{n}^{\circ} 3$ de Beethoven e, no final, apesar do tom ser menor, o lirismo era tão ardente que tudo ficou entendido, entre mim e a minha feiúra: eu a amava e não a abandonaria até a morte.

3. Meus primos (publicada na revista Manchete em 25/7/1953, recolhida no livro $O$ jornal de Antônio Maria)

Nós éramos uns quinze primos feios, quinze loucos e passávamos as duas férias do ano em Cachoeira Lisa, herança do nosso avô honrado, uma usina que, em 1924, não devia um tostão a ninguém mas que, em 1946, foi torrada nos cobres por dois vinténs, porque suas dívidas eram terríveis e insustentáveis. Dormíamos num apartamento enorme - sala imensa e um banheiro de bom tamanho e em quinze camas de lona, com um lençol, uma baeta e um travesseiro para cada menino. Cada um tinha sua manta. R. A., por exemplo, adorava caçadas. Um dia lhe disseram que, na mata do sítio Curuzu, havia uma árvore cujos frutos eram uma comida querida de todos os passarinhos da redondeza. Alguns caçadores, quando anoitecia, iam para lá, deitavam ao pé do tronco, cochilavam e, de manhã cedinho, acordavam com a cantoria dos bichos e cada tiro que davam era uma juriti ou trocaz no embornal. R. A resolveu ir também, mas como era, antes de mais nada, um comodista, levou cobertor, travesseiro, um colchão, candeeiro de querosene e um volume de Os Maias (Eça de Queiroz) para ler, enquanto o sono demorava. Achamos graça em seu equipamento e, à sua saída, ainda perguntamos quando voltaria da África. No dia seguinte, entre oito e nove horas, R. A. deveria voltar com seus passarinhos mortos. Mas deu dez horas, onze, meio-dia e nada. Ficamos sobressaltados e fomos para a mata de Curuzu, um pouco desconfiados que uma cobra ou um gato-do-mato o houvesse apanhado. Procuramos, gritamos seu nome, até que, uma hora depois, embaixo da tal árvore, R.A. dormia como um justo, coberto até o nariz, com o candeeiro aceso e o livro de Eça aberto na página que dizia: "Foi num sábado que Afonso da Maia partiu para Santa Olávia. Cedo, nesse mesmo dia, Maria Eduarda...". Com o seu comodismo, havia feito uma cama gostosa demais. Leu, adormeceu e, como a friagem da manhã estivesse muito 
gostosa, dormiu, perdidamente, até uma da tarde, hora em que o encontramos, todo cuspido de passarinho.

R.G. era um demônio. Mais atleta, mais afeito à terra que qualquer um de nós, era uma espécie de Tarzan, filho do mato e do rio, diante da nossa meia tendência para o asfalto. Numa tarde, resolvemos caminhar pela estrada de ferro - e outra coisa não pretendíamos senão dar uma olhada na filha de um vigia novato, morena carregada, de olhos verdes e longas tranças que, de tardinha, lavava os pés, enfeitava a cabeça com uma flor e vinha para o patamar de casa tocar viola de 12 cordas e cantar "Sussuarana". No meio do caminho, demos com a ponte de ferro, feita de trilhos, dormentes e mais nada, onde só o trem podia passar. R.G. teimou que atravessar seria uma canja, andando por cima dos dormentes. E se o trem viesse? - aventamos essa perigosa possibilidade. Não ligou. Nós ficamos no barranco do rio e ele começou, sozinho, a travessia. De repente, parecia coisa do diabo, o trem saiu da curva, a cem metros da ponte. R.G. ia exatamente na metade e não tinha tempo de correr para frente ou para trás. Fechamos os olhos, pensamos em Deus por sua alma de 16 anos. O trem passou, houve um minuto de pausa e, depois, R.G. apareceu no mesmo lugar, fazendo gestos vegetais e gritando que não seria a locomotiva da Great Western que o mataria tão jovem. Garoto de incrível presença de espírito, quando viu o trem à sua frente, agachou-se, segurou, com as mãos, um dos dormentes e deixou o corpo pendurado. Depois que passaram os 12 vagões, suspendeuse como num exercício de barra e começou a rir do estado de pânico em que estávamos. O maquinista, ao chegar à estação de Gameleira, a dois quilômetros dali, entregou-se à polícia, confessando que tinha matado um menino da usina Cachoeira Lisa.

Primos e primas, seis moças e seis rapazes, resolveram passear a cavalo num engenho nosso, que se chamava Cuiambuca. Saíram de madrugada e prometeram voltar às três da tarde. Acontece que deu sete horas, estava quase escurecendo, e nada deles voltarem. Como era negócio de moças e rapazes, embora primos, as mães ficaram meio assustadas. Eu e Tião, porém, sabíamos que o grupo voltaria são e salvo. Planejamos ir para Volta da Jaqueira, frequentado por fantasmas e almas penadas. Quando os cavaleiros surgissem, Tião, embrulhado num lençol, iria para o meio da estrada e ficaria parado, rezando, aos berros, uma jaculatória pelo repouso dos espíritos desassossegados. Fiquei atrás da jaqueira e quando ouvi o tropel dos cavalos, mandei Tião, com o seu lençol, para o meio do caminho. Nossos primos, tomados pelo susto, em vez de correr, baixaram os rebenques no pobre do Tião, que, durante quinze minutos, apanhava e gritava: "Não tem 
graça não. Vocês sabem que sou eu". Do meu esconderijo, queria intervir, mas a crise de riso era tanta, que não conseguia sair do lugar.

São estas as pobres e perdidas recordações, embora sem ternura para os outros, de que me sirvo nos dias de saudade. Meus quinze primos, espalhados, desarrumados no mundo (um deles é frade dominicano, em Paris), são hoje, nestas coisas que conto, minha única maneira de voltar ao moleque da campina, que não sabia nada e era rei de tudo, para quem o remorso foi uma simples palavra do catecismo, no tempo em que a reza da noite redimia as viagens impossíveis do sexo. Não desprezeis minhas humildes saudades, mas buscai, em vossa meninice, lembranças parecidas com estas e elas vos restituirão um certo apego, um pouco de bem-querer aos dias de hoje, tão sem graça em sua maioria.

4. A senha do sotaque (publicada na revista Manchete em 1/11/1953, recolhida no livro O jornal de Antônio Maria)

Faltavam uns oito dias para o carnaval de 1941 e eu entrava, sem paletó, sem moral e sem camisa, segurando as calças com as mãos, num compartimento úmido e fétido da Polícia Central do Rio de Janeiro. Os outros presos batiam samba em latas de goiabada e cantavam uma toada, que dizia: "aquela que me acompanhava na minha jornada partiu para onde, eu não sei”. A água fria que, de 10 em 10 minutos jogavam na barriga da gente (para acalmar), escorria no cimento lodoso, misturada a feijão, a restos de carne, a urina e fezes. A cadeia estava cheia demais e ao procurar um cantinho onde pudesse me acocorar, era ameaçado pelos olhares dos que haviam chegado primeiro. Ai de mim se pisasse alguém. Acocorei-me, afinal, entre um mulato e um brancoso e comecei a tomar conhecimento da minha situação. Vi-me só, esquecido, ignorado e inúteis eram todos os bens que pudessem me querer. Minha mãe, coitada, por mais que me amassse, que jeito me daria o seu amor, tão longe estava de mim e de minha miséria? Minha namorada, tão aflita que sempre tinha sido em relação às minhas artes, por mais telefonemas que desse, jamais saberia de mim. Meus amigos outra coisa não podiam fazer, além de ficar tristes, trancados num apartamento do Edifício Andraus, esperando notícias e pedindo a Deus que eu chegasse antes deles. Naquele exato momento, compreendi a grandeza do homem que tem de valer por si mesmo, pela sua dor, pela sua desproteção e, sentindo a imensa coragem dos desvalidos, os meus olhos, que vieram suaves e mansos, se tomaram do mesmo ar de desafio, da mesma arrogância, que havia nos olhos dos meus irmãos, 
assassinos e ladrões. Podia haver o que houvesse e minha dor não teria gemidos, podiam me dar de chicote até eu virar ferida e não diria a ninguém que parasse. Foi quando rangeu o cadeado da porta de grades e disseram meu nome por extenso. $\mathrm{O}$ mulato à minha direita, palpitou por conta própria: "acho que vais apanhar". Eu também achava. Mas, quando me vi no corredor, lado a lado com o guarda que me viera buscar, o destemor era tão grande, o desapego da vida era tão frio e real, que lhe disse já em tom de briga: "na hora de bater, bata em lugar que mate; ou, então, bata longe". O policial parou de repente e me fez parar, também, segurando-me pelo cós das calças. Olhou-me com ódio e eu o olhava com desprezo. Estávamos há cem anos de olhos pregados um no outro, quando veio um guarda de talabarte e perguntou o que era que estava acontecendo. Tirou os olhos de mim e respondeu: “nada. É o preso que está querendo cigarro". Meteu a mão no bolso e ofereceu cigarros Liberty. Tirei um, botei atrás da orelha e continuamos andando.

Uma hora depois, eu tinha sido solto e estava na rua, sem saber que caminho ia tomar. Por um desses raros e importantes acasos da era de Filinto Müller, ninguém tinha me batido. Então, o mesmo guarda, que eu pensei que fosse um mau sujeito, estava me esperando na esquina. Disse que, da outra vez, eu fosse menos valente e, quando soube que eu morava em Copacabana, deu-me vinte mil réis para ir de táxi. Tinha sotaque de pernambucano.

5. Vigésimo aniversário (publicada no jornal Última Hora em 5/4/1961, recolhida no livro Benditas sejam as moças)

Comemoro hoje, em intimidade, os meus primeiros vinte anos de crônica. Como não tenho a menor esperança de completar outros vinte, sirvo-me de um whisky puro e beboo festivamente, não em homenagem, mas em lembrança de tudo quanto passei.

- Tua saúde, homem!

Comecei no Recife, em abril de 1941, via pistolão, após receber de volta onze crônicas que entreguei, pessoalmente, ao secretário do jornal. Fui publicado, afinal, descrevendo uma mulher que vira na Rua Nova e que face a ela me colocara "com a humildade de um mendigo diante de um prato de comida". A imagem fez muito sucesso entre quatro ou cinco amigos, na calçada da Fênix, em Recife. Mas foi só. À noite, quando 
fui levar a segunda crônica, o secretário trancou-se comigo em seu gabinete e passou-me este carão:

- A Norma Shearer (havia-lhe elogiado o “estrabismo lascivo de Norma Shearer”) de quem você falou é esposa de um anunciante nosso, que mandou suspender o anúncio da edição de domingo. Você, hoje, tem que escrever qualquer coisa explicando que a semelhança de sua personagem com qualquer pessoa é mera coincidência.

Depois:

- Já vi que você quer ir no caminho de Rubem Braga. Mas fique sabendo que, em cidade pequena, isto é impossível.

Segui dali para a frente tomando imenso cuidado com qualquer coisa que pudesse desgostar o anunciante. Na mesma crônica de estreia, a revisão me atingira pela primeira vez. Corrigira "mendigo" para "mendingo". Na do dia seguinte, sobre carnaval, saiu "sempertina". Em vez de "serpentina". Pensei muito em abandonar o jornalismo. Por dois motivos: o anunciante e a revisão.

Aqui, no Rio, em meus começos, por mais que procurasse evitar, escrevia sempre para uma minoria, que frequentava o Vogue. Moças educadas no Sacré-Cœur, que me chamavam, suspirosas, de poeta. Causavam-me náuseas os olhares oleosos com que me diziam o elogio. Tudo falso - o olhar, a voz, o flirt ficeleiro que me ofereciam. Na época, o Petit Prince estava muito em moda. Era chic citar-se o diálogo da raposa com o "pequeno príncipe". A raposa a dizer que era preciso primeiro cativar. Aquilo me enfadava, de tão repetido. Uma vez me disseram que eu era o Saint-Exupéry do Brasil, e passei a fugir de toda aquela gente prodigiosamente tola. Entediava-me, depois de tanto viver, ser o "Exupéry do Sacha's".

Faço, hoje, vinte anos de cronista. Andei um bom pedaço de mundo e conheci um sem-número de corações. Tranquei-me em casa depois. Não gosto de escrever. Se soubesse fazer outra coisa, mesmo que fosse um contrabando, não escreveria coisa alguma. Mas preciso escrever e tenho que continuar. Encontrei, porém, um caminho melhor. Meu leitor não é mais a moça educada no Sacré-Cœur. É o portuário Porfírio. É o candango demitido, em Brasília. É a funcionária pública, cujo salário não lhe paga o almoço na cidade. É uma gente que existe. A viver males que existem. Homens e mulheres de verdade, para quem a raposa de Saint-Exupéry tem uma importância muito 
limitada. Faz-me bem, ao tomar este whisky comemorativo, saudar o novo público de carne e osso:

- Saúde, leitor!

6. Fortaleza de Nossa Senhora d'Assunção (publicada na revista Manchete em 12/9/1953, recolhida no livro Pernoite)

Minha amiga, seguindo o caminho do seu guia, seria transferida para Fortaleza e vem saber o que eu acho da cidade. Lá, passamos todo o ano de 1944, um comecinho de 45 e teríamos ficado para o resto de vida, se não fosse o telegrama "western", que dizia: "siga Bahia”. Mas, Fortaleza e sua gente são mais ou menos assim: a rua principal chama-se Guilherme Rocha, onde o principal hotel (Excelsior), há quase 10 anos, já era uma moradia insuportável. De algumas janelas, vê-se a Praça do Ferreira, com os seus bancos, onde sentam homens graves, lendo "O Povo" (vespertino de propriedade do senhor Paulo Sarasale), conversando sobre seca e política. Em toda a volta, estacionam automóveis de aluguel - sempre muito novos e, de preferência, Buicks - e seus motoristas organizam grupos para falar de futebol e dar vaias nas pessoas que se vistam ou que caminham de maneira estranha. Os melhores recantos residenciais são: Aldeota (bairro de casas modernas), a praia de Iracema - se o mar ainda não a engoliu por inteiro - e todo o caminho do Benfica, onde o casario é mais sisudo e o silêncio da noite ajuda uma grande paz para quem foi dormir em estado de graça. A cidade é toda quadriculada e as ruas, que são compridíssimas, dão a entender que foram traçadas com uma régua.

HÁBITOS - O cearense acorda cedo e nunca dorme depois das 11 horas, com a exceção do dr. Bié e dos amigos que o cercam. Quando o verão aperta um pouco, depois do jantar, os casais costumam passear nas calçadas (isto vi muito na rua Joaquim Magalhães), ela de peignoir e ele de pijama. Se chove, o distinto é vestir um calção ou desvestir-se completamente e ir tomar a chuva nas costas, aos gritos de alegria, com uma cachacinha antes e outra depois. As famílias se visitam muito, quase sempre após o jantar e, com as cadeiras na calçada, ficam horas e horas adivinhando invernos.

DIVERSÕES - Vêem-se duas fitas por semana, no cinema Diogo, em sete soirées, sete matinés e em uma matinal, que acontece aos domingos, às 10 horas. Além disso, tendo coragem, o cidadão poderá comparecer a uma das sessões-colosso, com 11 filmes 
diferentes, no velho cinema Majestic. A dança é um divertimento semanal, que pode ser praticado no Ideal Clube, no Iracema e, agora, se não estou enganado, no Náutico e no Maguari. Os domingos eram enormes e, de manhã, a praia ficava cheia (de homens, na maioria, porque mulher de maiô provocava muito diz-que-diz. Um par de coxas de fora queria dizer que a mulher era doida, carioca ou tinha passado muito tempo nos Estados Unidos)... mas, dizíamos, a praia ficava repleta e o mar exuberante em suas marés, de vez em quando matava um. O futebol local era jogado em um campo só - Estádio Getúlio Vargas - e os grandes quadros foram: Maguari, Fortaleza e Ferroviário. A diversão mais barata e, por isso, mais frequentada, era o passeio domingueiro da rua Guilherme Rocha, que fica cheia, de ponta a ponta, entre 7 e 9 da noite.

COMIDAS E BEBIDAS - O prato regional cearense, a comida que realmente se oferece, com orgulho e prazer, é a panelada, feita com as vísceras do boi e acompanhada com um pirão fabuloso, que toma o gosto de toda a imensa mistura de tripas, fígado, sangue etc. Depois de uma dessas temerárias aventuras da fome, se o cidadão beber um copo d'água gelada, é obrigado a dormir, esteja onde estiver, e dormir de rede, como aconselham a ciência e o bom-senso. Fazem-se também, ensopado e sopas de peixe e camarão, mas, por serem considerados pratos leves, são servidos como complementos da panelada. Para esfriar o corpo, bebem-se cajuínas, refresco de pega-pinto e carapinhadas (sorvete batido em ponto grosso). De um modo geral, não há um cearense que não goste de cerveja e aguardente, com um bom tira-gosto, no caso: uma pata de caranguejo, frita no azeite e coberta de ovo. As águas têm nome. Chama-se: do Acarape (ruim de gosto), da Pirocaia, da Floresta e da Zuca Acioly.

AS GRANDES FIGURAS - Chegando a Fortaleza, é necessário querer bem ao prefeito Paulo Cabral, a Orlando Mota, Otacílio Colares, Girão Barroso, Artur Eduardo Benevides, Eduardo Campos e Aluísio Medeiros, poetas, jornalistas e pais de família. É mais do que necessário conhecer e amar uma senhora, que se chama Glorinha Pestana, parteira que, até 1944, havia ajudado cerca de 3.000 cearenses a nascer, inclusive os "4 Ases e Um Coringa". Andava de charrete, de porta em porta, visitando suas clientes - a maioria gente que não podia pagar - sem horas certas para comer e dormir. Nenhuma vida, até hoje, entre as que eu tenho tido notícia, foi mais dada ao próximo, sem espera de pagas, sem outro interesse que não fosse o de ajudar. Lembro-me de sua casa, na Aldeota, onde guardava, carinhosamente, a saudade de um filho morto, cuja repetida 
memória estava em cada canto da sala, em cada quadro da parede e naquele céu de um azul infinito, onde, numa manhã, seu avião passou pela última vez.

De um jeito saudoso, quero bem a Fortaleza, a loura desposada do sol!

7. Bahia, galinhas \& festas (publicada na revista Manchete em 11/3/1953, recolhida no livro Pernoite)

É com imensa saudade de coisas e pessoas, que vamos falar da "galinha do Manoel", a melhor comida de toda São Salvador. Até hoje, ninguém pôde fazer uma ideia de como aquelas maravilhas são preparadas e quem cometeu a ingenuidade de pedir receitas, voltou ignorando-a mais do que nunca, tão hábil é o despistamento do proprietário desse bar triste, onde nada é especialmente romântico, nada foi projetado, mas onde aconteceu tanta coisa da Bahia. Vem uma travessa imensa e são seis ou oito galinhas, nadando em molho gordo e escuro. A padaria ao lado, cúmplice desse misterioso assado, mandou o pão estalante e quentinho que, daqui a pouco, estará enxugando a graxa gostosa de um prato que precisa ser batizado. Com Odorico Tavares, num domingo de não fazer nada, resolvemos chamá-la de "Galinha ao Mobiloil 40" e foi assim que a apresentamos a Aníbal Machado, Rubem Braga e à moça Tônia Carrero, que vinham da Europa e ficaram conosco (Anízio Teixeira também estava) durante dois dias, enquanto a estiva, preguiçosa e politizada, prendia o Poconé no cais. Se Deus ainda me quiser na Bahia, nem que seja por umas horas, eu quero ir buscar uma porção de saudades naquele canto da Barra. Quero, também, pagar os 300 mil reis que eu devo ao Manoel - única fatura baiana que não liquidei, quando vim de lá, em abril de 48. Se alguém está de viagem marcada para esses dias, em Salvador, encontrará duas festas - a da Aleluia e a do Espírito Santo, no domingo de Pentecostes. De passagem pela barra, será um crime perder a "galinha do Manoel", feita sem dendê, sem pimenta, sem nada da tradicional comida afro-baiana, mas, boiando naquele molho, cuja receita ninguém obterá jamais. A rua e o número eu nem me lembro. Mas, fica ali defronte do mar, perto do farol, atrás do edifício Oceania, quase na esquina onde se cruzam e dobram os bondes de Barra e Barra Avenida. É só perguntar, que todo mundo ensina.

Nenhuma cidade do mundo tem tanta festa de rua. E todas elas pertencem ao povo, à gente mais tipicamente baiana, a ponto de manter sempre como espectador: jornalista, gente de dinheiro, poeta ou turista que, nelas, queiram tomar parte. É necessário ser pobre, 
baiano e, se possível, negro, para conquistar o posto de personagem numa procissão do Bom Jesus dos Navegantes ou na imensa noite campal da Senhora Sant'Ana, no Rio Vermelho. Contente-se em ver os outros - e já será uma graça - se lhe viera a felicidade de acompanhar, de janeiro a janeiro, as festas de rua da Bahia. Farte-se do espetáculo dos capoeiristas das rodas sambeiras, dos reisados. Abuse daquelas generosas melancias de Conquista e não se dê ao luxo de evitar que o caldo, escorrendo, the molhe o peito e camisa. Mas, não pense em ser mais que um mero espectador, porque a festa de Iansã (Santa Bárbara), na Baixa do Sapateiro, é dos pais-de-santo, das "baianas", dos negros do cais e da Praça Cairu. A Conceição da Praia tem muito o que olhar. São centenas de barracas, em volta do Mercado Modelo, com os nomes mais líricos do mundo, vendendo comida de azeite. São tabuleiros enormes de abacaxis, melancias, pinhas e umbus. É a zuada dos berimbaus e dos chocalhos, o canto do tirador, enquanto os capoeiristas fazem "letra" no chão. O cheiro da cachaça, no suor e no hálito dos sambeiros, no vento e na cantiga da roda de samba. A Igreja, bonita que só ela, toda iluminada, onde se reza a novena para louvar Nossa Senhora da Conceição - louvar, somente, porque o povo está feliz e não pede nada.

Gente pacata, a da Bahia. A incomparável doçura do povo rende os nove dias da Conceição da Praia, sem uma cena de sangue, sem uma briga de sopapo. Discutir discutem, porque quem é baiano tem que bater boca a vida inteira. Mas, nada de estragar a roupa e a pele do outro. No Recife, em festas mais humildes (só de barraquinhas de prendas e carrosséis), a confusão era tanta e depois de certa hora, exército, polícia e povo se entendiam tão pouco, que o jeito era o tiroteio. Feliz de quem pode estar na Bahia, a 8 de dezembro, e assistir a uma Conceição da Praia. Noite e dia, o zabumba comendo, o povo cantando, dançando e, como anotou o samba de Caymmi: “o sol está queimando, mas ninguém dá fé".

Em janeiro é a festa do Bonfim. Gente, comida e alegria são as mesmas. O lugar, porém, é mais bonito e o ritual tem aquela nota aguda e chocante da lavagem da igreja, quando o povo canta e dança no templo, derramando extrato, loção e água no mosaico. O arcebispo - hoje, cardeal - muitas vezes já conseguiu proibir essa cerimônia, apontandoa como profanação à casa de Deus. Mas, são tantos os protestos, que se vê na obrigação de ceder sempre. As festas de rua da Bahia são uma longa história a contar. 


\section{O piano (publicada no jornal Última Hora em 11/6/1952, inédita em livro)}

Chovia na minha rua e tocavam-se valsas de Chopin. A casa do lado, de D. Marocas Filgueira, tinha dois meninos e duas meninas, todos dentuços, que sabiam de cor o adágio da "Sonata ao luar", de Beethoven. Apesar da chuva, eu ia espiar, por uma fresta na janela, o jeito daqueles meninos magros, espetados na ponta do cóccix, meio debruçados nas estantes, dando gosto e esperanças à família pacata da rua da União - em algum tempo, rua Rodolfo Araújo, em homenagem ao meu avô - musicando a tarde chuvosa. E me deu aquela vontade enorme de tocar piano. Falei em casa, contrataram Dona Arlinda Rocha e comecei a aprender. Meus dedos eram duros e exercícios não me falavam ao coração. Odiei o primeiro dia da "Marcha turca", de Mozart. Fui largando, largando, até crescer sem tocar Chopin. É o mal que mais me dói. Das coisas que queria ter sido e que não fui, pianista é a que mais lamento. É por isso que, hoje, ao jovem e pálido repórter que nos vem entrevistar, respondo todo malfeliz: "Eu escrevo programas porque não consegui tocar Chopin". Queria tocar aquelas valsas que ficaram na rua chuvosa, nas paredes dos sobrados molhados, nos dedos dos meninos dentuços que, provavelmente, já morreram de tísica.

9. Pensa, Pedro (publicada no suplemento da revista A Noite Ilustrada, inédita em livro)

Eu te escrevo para pedir que não venhas, Pedro. Vai ser bonito, se chegares num dia claro, de céu azul, de praia cheia de gente. Será um deslumbramento a moça saindo do mar com um maiô tão pouco e o busto tão muito - e se deitar na areia, a rir das tuas ombreiras e das bocas das tuas calças. Sentirás o que eu senti, há doze anos, e escreverás a todos os teus amigos. Mas é melhor que não venhas. Será uma alegria apertar a mão da estrela do rádio, pensar uma coisa bem agradável, dizer e perder o fôlego. À noite, irás fazer a ronda dos bares de Copacabana, conhecerás os poetas, cronistas e pintores. Verás a moça do cinema, uma outra do teatro, verás gente de livro e de jornal. Dirás: será mesmo aquele o Rubem Braga? E o Braga te dirá uma frase bem curta, para que tu não entendas e ainda te sintas feliz. De que te servirá a apresentação ao poeta Bandeira se, com toda certeza, ele não vai gostar dos teus versos? Para que o tempo e a emoção de entregar os originais do teu livro de contos ao escritor Álvaro Lins, na esperança de uma edição José Olímpio? 
Depois, quando passar o ineditismo, quando vires a rua e as gentes, os automóveis e a polícia - tudo sofrendo, Pedro - vais sentir saudade da tua rede, do jardim da tua casa e saudade de ti, quando eras puro. Não troques o ensopadinho da tua casa, a conversa da família em volta de ti, as horas certas de almoço e jantar, pelo restaurante francês que te obrigará a comer sempre o que não pretendias, sozinho numa mesa ou ao lado de uma mulher que não te quer muito. Não deixes o teu quarto - com o teu guarda-roupa, tua estante de livros e aquela cadeira onde há sempre um paletó - pelo cômodo ruim que vais ter em Copacabana. Não te deixes deslumbrar pela palavra "apartamento" como eu me deslumbrei, há doze anos, a ponto de esquecer a palavra "sobrado". Hoje, eu queria tanto voltar ao sobrado e não posso. Todo mundo vai dizer que eu fugi e todos estão de olho em mim. Vim andando ao longo da praia, vim deixando, na areia, as marcas das minhas botinas e todos me seguem, e todos me descobrirão, e todos sairão correndo e gritando, se eu tentar escapar: pega o ladrão! Pega o ladrão!

Fica, Pedro. Tua cidade é tão linda. Se o que te inquieta é o sossego, agita-te dentro de ti mesmo. Depois, em volta de ti. Cria um caso, rouba a mulher do outro, foge para o mato e, quando voltares, sorri para quem te ameaçou de morte. De noite, vai à boite, pede uma "bebida fechada", acende o teu cigarro e todos te olharão empolgados. Faze de ti um ídolo daí e não ouvirás o chamado do navio, que some no fim do mar, nem o voo do avião, te chamando todo dia.

Fomos uns dez e viemos na mesma leva, Pedro. Acreditamos em páginas de revistas, telegramas de jornais e notícias de rádio. Fomos na conversa dos que vinham passar tempo e voltavam contando coisas, falando sem esta sinceridade com que te digo, agora, verdades tão cruas. É verdade que experimentamos uma porção de alegrias, que nos deslumbramos centenas de vezes. Mas, agora? Tudo o que acontece é reprise, com os mesmos personagens, o cenário mesmo, causando-nos a mesma saciedade que te causa, aí, a repetição do teu dia.

Arranja um jeito, faze uma força e fica, Pedro. Não venhas pela moça de maiô, pela boite que acaba de manhã, nem pela vontade de vencer na vida. Vida não é páreo e, se é, ninguém vence. Esbaforidos, imprestáveis, chegamos todos empatados. Se vieres e se um dia pensares que venceste, vais ver que ganhas muito e vives pouco. Tentarás voltar, mas, atrás de ti denunciando, estarão as marcas dos teus pés, na areia da praia, e haverá um bandão de gente louca para gritar: pega o ladrão! Pega o ladrão! 
Pensa, Pedro: valerá a pena?

10. Carta de mãe (publicada no semanário Comício em 29/8/1952, inédita em livro)

Quando nascestes, eras tão volumoso que a parteira te trouxe, após o banho, ergueu-te à altura do seio materno, dizendo-me isto:

- Toma-o: bota vinte litros!

Nessa noite, crianças morreram de difteria, mulheres deram à luz três filhos mortos e ninguém nasceu vivo - só tu. Na manhã seguinte, choveu muito e o homem do cuscuz não passou.

Como vês, és um pouco diferente dos outros e tens que tomar uma porção de cuidados pelos caminhos da vida. Tua primeira babá pôs pimenta em teus olhos e tentou quebrar tua moleira com um bilro de fazer renda. A segunda, a que se chamava Florinda, aproveitando um momento em que não havia ninguém por perto, deu-te um conhaque Macieira para beber. Aos dois meses, tiveste que usar óculos escuros por causa de uma irritação causada pela pimenta. Custaste muito a falar a tua primeira palavra: foi "feijão". Quando saíste de casa, levaste muita bênção e pouco dinheiro - mesmo porque, se escolhesses pouca bênção e muito dinheiro, ias me deixar em falta. Mas deves estar lembrado do quanto choramos abraçados e quantas vezes te recomendei um milhão de cuidados. Pedi que não dormisses sem a tua touca, que não bebesses água fria depois do café, e que não te metesses com mulheres cheirosas de olhos pidões.

Hoje, é a quinta vez que te escrevo, para pedir que não te metas a cronista de jornal. Cinco cartas te mandei e cinco vezes não deste a mínima importância aos cuidados de tua mãe. De que te serve o jornal? Tu começas a escrever, dizem que és muito engraçado e, depois, não sei por que, o dono do jornal te despede. Tu não sofres, porque és mesmo um caráter grosso, mas te abismas em pensar como depois de receberes tantas felicitações dispensam tua colaboração.

Faze o que sempre te pedi. Fica em teu rádio.

Se sabes fazer programas musicais, se inventas histórias e ganhas o de que viver, por que ainda te metes em jornal? Aqui, cobrindo-te de bênçãos e rezando a Deus pelos teus minutos, 


\section{É A TUA}

11. As três fotografias (publicada na revista Manchete em 31/1/1953, recolhida no livro Pernoite)

A gente assiste ao cigarro se gastando, ouve os carrilhões da vizinhança, vê a chegada das noites e não se apercebe de que tudo isso é o tempo, andando. Os espelhos são de uma discrição fabulosa e não nos contam nada, de manhã, quando lhes perguntamos as coisas. Mas, quem sabe de nós é o retrato $3 \times 4$ da carteira de identidade. Toma o teu, espia bastante para ele, amigo, e verás que horas são, nos teus cabelos, na preguiça dos teus olhos e no corte vincado da tua boca.

Aqui estou eu, diante de mim, em três fotografias coladas nos documentos que me dão trânsito livre pela vida em fora: a carteira de identidade, a de chofer e o passaporte.

- Como vais tu, rapazola do Recife, em março de 1940? Eras um herói e vivias de muitas esperanças. Mandaste fazer uns ternos, uma porção de camisas e inventaste de comprar um chapéu. Depois, recebeste uma passagem do Almirante Jaceguai, uns abraços no tombadilho e muitos adeuses no cais. Um daqueles lenços era o da tua namorada, que, um mês depois, já nem se lembrava de ti. Mas, o mundo era generoso e te daria outra. À bordo fizeram uma roda de moças e contaste umas histórias inventadas, que alcançaram muito sucesso. Houve quem não acreditasse nos teus anos e mostraste a carteira de identidade. Acharam que tu eras um prodígio e, de lá para cá, até hoje, não fizeste outra coisa, senão inventar histórias para engabelar e conquistar os outros.

Agora, sabes dirigir automóvel, tens um bigode de carta de baralho (rei de espadas) e os teus olhos são penetrantes. Tua boca é de quem já provou beijos mais maduros. O que se vê do teu corpo - os ombros e o peito - é de gente que faz exercício, que cuida de si, pensando nos outros. Estavas na Bahia e gostavas de ver quem passava de navio. Vinha gente do Norte e do Sul, descia, saía contigo para olhar igrejas, praias e antiquários. Contavas uma porção de histórias e todos achavam muita graça. Ia contigo ao almoço na melhor comida da terra e ao banho de praia mais serena. Davas uma ordem e os atabaques de um candomblé começavam a bater, embora não fosse o tempo. Pai de Santo te levava ao pegi e dava explicações para os teus convidados. Depois da função, ainda meio 
transidas, as ogans vinham sorrir e te abraçar. Os teus amigos se encantavam com o teu prestígio. O teu show era tão completo e, dele, falavam tanto que, tempos depois, quem fosse passar em Salvador já te mandava telegrama, porque percorrer a cidade, sem ser pela tua mão, até nem tinha graça. E assim conheceste uma porção de gente - jornalistas, poetas, moças, políticos, artistas, viajantes de perfumarias e laboratórios. Na época das festas, estavas sempre com os capoeiristas e sambeiros, na Conceição da Praia, no Bonfim e na Ribeira. Na tarde de Iemajá, ias, com os pescadores, e levavas uma braçada de rosas para Janaína. Não acreditavas em nada daquilo, mas, era uma festa de flores e canções, que te enchia de muita beleza. Além disso, os pescadores e mestres de saveiros gostavam de ti e não perdoariam a tua falta, a 2 de fevereiro. Esta fotografia foi tirada em 1946. Teu jeito, diante do que está na carteira de identidade, é de um homem que já viveu um pouco e ainda pensa em viver muito mais.

Dá uma espiada, agora, no retrato do teu passaporte. É recente. Que é daquele meio sorriso de vitória, que é do bigode de tendências esquerdistas? E os ombros, e o peito de nadador? Onde deixaste os teus cabelos, que nunca foram belos, mas eram tantos, a ponto de te dar trabalho de manhã, com pente e escova? E os teus olhos? Estão cheios de tristeza. Os outros não notam, porque eles são pequenos e ninguém acredita que tristeza muita possa caber dentro deles. Mas, volta aos dois antigos retratos e vê o jeito e o brilho do teu olhar - vivo, mandão, crente e aventureiro. O de hoje nada mais faz que pedir. São olhos como as tuas canções, que essa gente canta e nelas se mistura, sem se lembrar de ti, sem se aperceber de que cada uma é história tua, sem ao menos te agradecer pelo que disseste. Não estás morto, eu sei, mas, feneceste, moço. A culpa não é do Almirante Jaceguai, que saiu contigo, ensinando-te a ser vagabundo. Mas é do carrilhão do vizinho gemendo os quartos de hora: é das tuas dores e das dores dos outros, que te comovem tanto.

Em São Paulo, na mesa escondida no fundo de um bar, viajaste através de ti mesmo, durante longos anos. Teu documento de identidade, tua carteira de motorista e teu passaporte foram portos de escala e neles pensastes estas coisas. Naquela hora, porém, apesar das dezenas de pessoas, que entravam, bebiam, falavam e saíam - ignorando-te uma certeza te salvou: longe, devia haver alguém que estava pensando em ti. E, se não houvesse era só porque estavas meio bêbedo... e ninguém gosta de pensar nos bêbedos. 
12. Everaldino com saudades (publicada na Revista da Semana em 12/6/1954, inédita em livro)

Everaldino, nome da Bahia, mãos e cabelos de melhor baiano. Encontrá-lo num restaurante da noite, em São Paulo, com ele comer carne e arroz, era uma coisa assim igual a estar no Café das Meninas, em Salvador. Seu ar e sua voz macia baianizavam por completo o salão, onde paulistas friorentos comiam. Contava suas histórias. Saiu da Bahia, como taifeiro, e foi andar pelo mundo.

Várias coisas cometeu pela vida afora, até ser escafandrista, no Golfo da Biscaia, trabalhando para um barcaceiro grego, que se chamava Papaulus. Sem querer, sem provocar, ficou amante de Maria, mulher de Papaulus, descendente de espanhola e - disse Everaldino - "a dos olhos cinzentos". Não sabe o que o levou para ela: talvez tenha sido o olhar, da cor das tardes chuvosas, da cor dos nevoeiros no mar. Talvez tenha sido a mão macia, que lhe afagou a cabeça, numa noite de febre. Talvez tenha sido simplesmente a solidão de um baiano exilado, largado por caminhos que só vira em nome - sem sonhálos - nas aulas de geografia do primeiro ano de ginásio. Não fora (disso tinha certeza), apenas, pelo prazer de trair.

Papaulus era um homem grave e vagaroso. Não perguntava nem contava histórias. Um dia, era tarde, viu Maria sair de um abraço do amante e desaparecer no corredor, que dava para a cozinha, consertando os cabelos. Sentou, pediu (a Everaldino) que lhe trouxesse a garrafa de Genebra, começou a beber e avisou que haveria mergulho na manhã seguinte. Everaldino preferiu sair para embriagar-se na rua, em companhia de pescadores seus amigos. Só voltou na hora em que tinham de sair para o mar. Sem dizer nada, foram os dois para o ponto onde seria o mergulho. Teriam que refixar uma boia - avisara o chefe - e, olhando com dureza os olhos do baiano, ajustou-lhe o redondo e feio capacete de escafandrista. Everaldino compreendeu que ia para a morte e sentiu o fundo do mar como um consolo e um descanso, uma punição e uma eternidade. Escorregou, devagar, pelas beiras do barco e sumiu-se.

Passaram-se os primeiros minutos, passou o tempo normal de imersão. Poderia ter tocado a campainha, apelado para o perdão do grego, mas não quis. Esperaria a morte, dentro do capacete de ferro. As algas e os peixes eram visões de despedida. E a transparência do verde lhe enchia de beleza o último dos mundos aos seus olhos. Foi 
quando sentiu um puxavante e, devagar, começou a ascender. Papaulus podia tê-lo deixado morrer e seria ali, sem denúncias, sem punição. Mas, não quisera. Trazia o mergulhador outra vez para o barco e, num gesto de grandeza, apertava-lhe a mão (sem sorrir, olhando-o outra vez com dureza) premiando-lhe a coragem de não ter pedido para salvar-se. Everaldino conta que, da praia mesmo, tomou rumo de viagem. Nem fora embora quisesse tanto - olhar, pela última vez, os olhos cinzentos de Maria.

Dali, andando sempre pelo mar, foi ser baterista de uma orquestra cubana, em Singapura. Eram seis músicos e, de cubano mesmo, só havia o pianista, que se chamava Juan de Luca. O maraqueiro era francês, o pistonista italiano e tanto o guitarrista como o rapazote da clarineta eram argentinos. Deixou a orquestra, um ano depois, para aventurar com tráfico de tóxicos, em Lourenço Marques. Everaldino me contava essas coisas mastigando, fazendo pausas como se quisesse gozar cada saudade, rindo de um ou outro pormenor que lhe vinha à lembrança. Por exemplo: Annie, a francesa que vendera toda a roupa de dentro para almoçarem juntos. E lamentava-se: "não conheço Paris; não passei do Havre".

Dez anos depois, voltava à Bahia como clandestino. As ruas eram as mesmas, a vista do mar, olhada das janelas dos fundos, em um sobrado da rua Chile, também era a mesma: saveiros, barcaças, o forte de S. Marcelo, a rosa dos ventos encravada no ladrilho da escola dos marinheiros. Mas, os amigos, que tinham sido três, tinham ido correr mundo também. Um estava no Rio - soubera - vendendo essência de extrato francês.

Mais um navio levou Everaldino, de terceira classe, até onde o dinheiro dava: Vitória do Espírito Santo. De lá, para seguir viagem, teve que lutar, num circo, contra um canguru, por trezentos mil réis. Empatou.

Perguntei-lhe, então, de tudo o que tinha feito, de que tinha gostado mais. Respondeu-me que só foi realmente feliz quando era farol de caricaturista, em Roma. Posava, nos cafés, para um jovem italiano chamado Adolpho, que sabia fazer seu perfil muito bem feito. Acabamos de comer. O garção trazia a nota que, com gorjeta, dava cem mil réis. Everaldino fez questão de pagar. Na saída, pediu-me duzentos emprestados. Despediu-se e, bem jantado, com crédito no restaurante e cem mil réis no bolso, dobrou na esquina da rua Aurora. Fiquei olhando-o, com inveja de um homem vivedor. Alguém bateu no meu ombro e tirou-me do êxtase. Era Dermival Costa Lima, que chegava em passo vagaroso. 
13. O caso (amoroso) de Pedro das Flores (publicada no jornal Última Hora em 6/11/1959, inédita em livro)

No "Romance policial de Copacabana", há histórias que mereciam ser contadas com fundo musical de violão. Aquela "Serenata do adeus", por exemplo, do poeta Vinicius, seria a ária ideal, para se contar, com as mais líricas palavras da língua, o caso amoroso do Pedro das Flores.

Pedro das Flores, o mais romântico entre os homens noturnos de Copacabana. Sua vida é quieta e bonita. Pelo menos aparentou, até hoje. Em cada acontecimento, havia uma rosa, uma margarida ou uma orquídea. Sai de noite. Vai de bar em bar. Em cada mesa, onde encontra um casal de namorados, deixa, timidamente, uma flor. O namorado paga, se quiser, quanto quiser, porque Pedro diz sempre que "as flores não têm preço". Mas, o feijão, sim... por isso Pedro guarda no bolso, sem olhar, os 50 e 100 cruzeiros por botão de rosa, que deixa nas mesas dos namorados.

Pena que a passagem de um Pedro das Flores pela delegacia, sendo, como é, uma notícia lírica, encontre um repórter tresnoitado, sem tranquilidade de tempo e sossego, para escrever a crônica merecida. É uma história diferente das outras.

Pedro vivia com uma mulher, havia 34 anos. Fartaram-se um do outro. Desgastaram-se, mutuamente. Ela pediu para ir embora. Pedro consentiu e, num gesto de gratidão, entregou 50 mil cruzeiros à companheira. Passaram-se os dias e a mulher começou a fazer falta - na casa e no coração de Pedro. Ah, florista, sua história é uma letra de samba já pronta. Só faltam as rimas, que Billy Blanco deverá fazer, como ninguém.

Ontem, Pedro compareceu ao $2^{\circ}$ DP. Quer a mulher de volta, de qualquer maneira. Com ou sem pecados. Quer que a polícia de Copacabana lhe traga o que era seu.

Pedro, você andou mal. Apesar de ver por aí tanta coisa, tanta história de amor dos outros, você errou, Pedro, em causa própria. Viu muito, mas aprendeu pouco. É sempre assim. Mulher a gente só manda embora depois de procurá-la bem em todos os cantos do coração (em todos os cantos da carne) e não encontrar. Mesmo assim, a gente não manda embora. A gente é que vai. E quem vai aprende o caminho de tornar... para que, um dia, numa agonia de saudade... É necessário ser-se reticencioso, ao escrever certas coisas, Pedro. Você precipitou, florista. Deixou que sua boca falasse antes do seu coração. E agora? É deixar a moça ir. Você já sabe onde ela está e ela lhe mandou dizer 
que se sente feliz. Portanto, não adianta a polícia. De nada servirão seu nome e o dela no Livro de Ocorrências. De nada. Para nada. Mande-lhe flores, com um recado (mesmo de mentira) que está feliz. Isso sim fica-lhe bem. Não adianta ser o mendigo de sensações impossíveis. Vá sua vida, pelos bares, pelas boates, como se nada houvesse mudado. Uma flor, um sorriso, uma frase de carinho para todos os namorados. Não deixe que ninguém descubra, em seu ar revelador, o grande sonâmbulo da noite. Porque os namorados e as flores não têm nada a ver com isso - continuarão. E você não tem outra coisa a fazer senão continuar. Obrigado por este capítulo do "romance". Perdão pela indiscrição de escrevê-lo. Em sua homenagem, porém, os outros casos, muito mais policiais que o seu, ficarão para ser contados amanhã. Coragem, Pedro.

\section{NOTA NECESSÁRIA}

$\mathrm{Na}$ tarde de ontem, começou a constar no Livro de Ocorrências do $2^{\circ}$ DP $\mathrm{o}$ comparecimento de Pedro das Flores, que recorria à polícia de Copacabana para que fosse localizada sua ex-mulher. As diligências tiveram êxito, mas a pessoa procurada, além de negar-se a voltar ao seu ex-companheiro, exibiu a carta assinada pelo queixoso, onde havia uma espécie de atestado liberatório, documento dos mais ricos e originais até agora encontrados por este repórter.

14. Legenda (publicada no jornal Diário da Noite em 29/11/1961, inédita em livro) Subamos a montanha, para mais alto. Tão alto que não nos possam mais chamar. Tão alto que nos esqueçam. Tão alto que eu veja a lagoa do tamanho de um orvalho. Tão alto que, lá embaixo, o presente se perca aos olhos e se transforme numa lembrança imprecisa. Tão alto que o passado fique, de repente, incerto e impresumível, como o futuro. Tão alto que possamos ver e sentir as primeiras luzes e as primeiras paredes do futuro. Chegar ao futuro de madrugada, pela primeira vez, como a uma branca cidade adormecida.

Quero estar tão perto de ti que eu não te veja. Tão perto, tão em ti, que eu te esqueça. É necessário que eu te esqueça um dia, que eu te perca um dia, dentro dos meus braços. E que me esqueças, por eu te pertencer, como uma camisa. Tu e eu. Eu sem mim. Tu sem ti. Ambos despertos, mas sem ser, sem ter, sem estar. Tu e eu, equidistantes do desejo e da saciedade. Tu e eu, durante... e o tempo sem som, desincumbido de nós.

Seremos tão sós que esquecerás o meu nome e eu esquecerei o teu. Para que é preciso ter um nome? Para saber, afinal, quem sofreu mais? Quem ganhou, quem perdeu? Quem irá merecer o milagre ou o castigo? Estaremos tão alto, tão unidos, tão sós, tão 
insubsistentes mesmo que os nossos corpos, sem fronteiras, dormirão do mesmo sossego, da mesma fadiga, do mesmo silêncio.

15. A ressaca (publicada em O Jornal em 14/8/1964, inédita em livro)

Está sendo difícil pra mim sair da cama. Muito. Acontece que ontem houve reunião em casa de amigos e, como fazia frio, bebi. Se não fizesse frio, beberia também, porque era "Dia do papai", consequentemente, meu dia, no que diz respeito não só a Maria Rita e Antônio Filho mas a todos os órfãos permanentes e temporários da vida. Bebi e, já que estava bebendo, dei cabo de uma garrafa. Aqui está Antônio, na cama, sem a menor possibilidade de levantar-se, escrevendo essas notas por conta de suas obrigações com Assis Chateaubriand e João Calmon.

O que é a ressaca? Na maioria dos homens o dia seguinte de um pileque e dor de cabeça, boca amarga, pés inchados. Em mim, nada dói. A ressaca é simplesmente um profundo estado de culpa. Todas as culpas caem sobre mim, desde as primeiras. Sinto-me culpado, por exemplo, de ter enfeiado o corpo de minha mãe, durante os meses em que fui gestado. De ter-lhe causado as dores das vésperas e a dor sublime de 17 de março de 1921. Fui a criança que mais doeu na família. Pobre dona Diva! E continuei doendo. E "douo" ainda hoje, por viver tão exposto às mortes da vida.

Esperanças, Diva! Daqui pra frente, embora não me sinta capaz de evitar-me os desvarios, evitarei ao máximo que eles lhe atinjam. Aqui estou eu, sem coragem para um só gesto. José Aparecido telefona e se queixa da minha influência nefasta em sua vida pós-revolução. Em dia de ressaca, aceito e assumo todas as culpas que me impõem. Sim, sou eu o culpado de todos os males.

E continuo sem poder levantar-me. Sem querer também. O homem de caráter é aquele que, mesmo podendo, não deseja levantar-se. Eu tenho muito caráter. Hoje, irei encontrar uma moça clara. Pelo meu gosto não iria. Tenho medo dela e de mim, também. Tenho medo de tudo quanto é mulher... e de mim, também. Sabe como é: no começo, tudo são flores. Depois, a gente gosta, vem os ciúmes... e adeus sossego. Vou encontrar uma moça clara e, com franqueza, preferia que ela fosse escura. Ou melhor: que ela não fosse. Mas, ela irá, eu direi o de sempre e acontecerá o de sempre. Riso, amor e perdição. Rir, rir, rir! Pobre moça! Pobre Maria! Mas que seja tudo por um Brasil melhor. 
Edith, minha cozinheira e diretora espiritual, trouxe a oração mais eficaz da Devoção a Santo Antônio. Chama-se "Cinco minutos diante de Santo Antônio" e começa nas disposições do meu padroeiro em relação a mim: "Sinto-me disposto a fazer tudo por ti, mas, filho, dize-me uma a uma todas as tuas necessidades".

Quero pouca coisa, meu padroeiro. Um pouquinho de dinheiro, para jantar com vinho, todas as noites, aqui no Bistrô. Coisa pouca. Uns 40 ou 50 contos para jantar com vinho. Queria, ainda, que o Walter Clark não me tratasse tão mal, preterindo-me, acintosamente, por amor a Nelson Rodrigues. Acho que é só, Santo Antônio. Saúde para dona Diva e para meus filhos. Os outros, todos os outros, já têm quem reze por eles.

Ah, sim. Ia esquecendo. Vê se melhora o bico de papagaio do José Aparecido. Melhorar. Curar, não precisa. No mais, que me passe essa ressaca. É só, Santo Antônio. Até amanhã. 


\section{Referências bibliográficas}

\section{DE ANTÔNIO MARIA}

MARIA, Antônio. O jornal de Antônio Maria. Rio de Janeiro: Saga, 1ª edição, 1968. . O jornal de Antônio Maria. São Paulo: Paz e Terra, $1^{\text {a }}$ edição, 1980. . Pernoite. Seleção de Leonardo Castilho e Sônia Mota. Rio de Janeiro: Martins Fontes/FUNARTE, $1^{\text {a }}$ edição, 1989.

. Com vocês, Antônio Maria. Seleção de Alexandra Bertola. Rio de Janeiro: Paz e Terra, $1^{\text {a }}$ edição, 1994.

. Crônicas. Excerto de Com vocês, Antônio Maria. Rio de Janeiro: Paz e Terra, $1^{a}$ edição, 1996.

. O diário de Antônio Maria. Organização de Joaquim Ferreira dos Santos. Rio de Janeiro: Civilização Brasileira, 1ª edição, 2002. . Benditas sejam as moças: as crônicas de Antônio Maria. Organização de Joaquim Ferreira dos Santos. Rio de Janeiro: Civilização Brasileira, 1ª edição, 2003. - Seja feliz e faça os outros felizes: crônicas de humor de Antônio Maria. Organização de Joaquim Ferreira dos Santos. Rio de Janeiro: Civilização Brasileira, $1^{\text {a }}$ edição, 2005.

. "Prefácio". In: PARANHOS, Myrthes. Coisas do mar: receitas culinárias. Rio de Janeiro: José Álvaro Editor S.A., 1ª edição, 1963.

\section{SOBRE ANTÔNIO MARIA}

ANDRADE, Carlos Drummond de. "Testemunha da noite". Correio da Manhã. Rio de Janeiro, 18 ago. 1964.

CAMPOS, Paulo Mendes. “Antônio Maria, sua noite durou quinze anos”. Manchete, n. 1.181, Rio de Janeiro, 07 dez. 1974, pp. 38-41.

CARVALHO, Hermínio Bello de. "Pernoite: nota explicativa". In: Pernoite. Seleção de Leonardo Castilho e Sônia Mota. Rio de Janeiro: Martins Fontes/FunARTE, $1^{\text {a }}$ edição, 1989, pp. XI-XII. 
CLAUDIO, José. “Antônio Maria irradiando feijoada”. In: Suplemento Cultural do Diário Oficial de Pernambuco, Recife, 1989.

FENDRICH, Henrique. "Antônio Maria e o jornal". Rubem: revista da crônica. Disponível em <https://bit.ly/2Uye1c1 $>$. Acesso em 12 jan. 2020.

FERREIRA, Raquel França dos Santos. "Antônio Maria: crônicas, memórias e Rio de Janeiro". In: Outros tempos, v. 6, n. 7, jul., 2009, pp. 209-226.

FRANCIS, Paulo. "Meus encontros com o bom Maria". O Estado de S. Paulo. São Paulo, 1984.

LINS, Vera. "Antônio Maria: Baudelaire nas noites do Rio". In: Cronistas do Rio. Organização de Beatriz Resende. Rio de Janeiro: José Olympio/CCBB, $1^{\text {a }}$ edição, 1995 , pp. 117-130.

MATOS, Maria Izilda Santos de. "Pelas noites do Rio de Janeiro: roteiro boêmio de Antônio Maria”. In: Corpos e emoções: história, gênero e sensibilidades. São Paulo: EManuscrito, 2018.

MELLO, Zuza Homem de. “Antônio Maria e Fernando Lobo". In: Música com Z: artigos, reportagens e entrevistas (1957-2014). São Paulo: Editora 34, $1^{\text {a }}$ edição, 2014, pp. 342-343.

MORAES, Vinicius de. “Antônio Maria: uma velha crônica”. In: Samba falado. Rio de Janeiro: Azougue, 2008, pp. 155-161.

NASCIMENTO, Débora. "Quando a noite era uma criança”. In: Bandeira B, revista da Bienal Internacional do Livro de Pernambuco, outubro de 2013.

NASSER, David. “Aventuras inéditas de um plantão noturno". In: Parceiro da Glória: 45 anos na música popular. Rio de Janeiro: José Olympio, 1983, pp. 30-33.

OLIVEIRA, José Carlos. "Antônio Maria”. In: O homem na varanda do Antonio's. Rio de Janeiro: Civilização Brasileira, pp. 89-90.

PHAELANTE, Renato. "Encarte”. In: MARIA, Antônio. A noite é grande - Antônio Maria. Direção artística de Hermínio Bello de Carvalho. Recife: BMG Ariola Discos Ltda., 1989, disco sonoro (32 $\mathrm{min}$.), 12 polegadas. 
RANGEL, Lúcio. “Ovalle e o outro”. O Mundo Ilustrado. Rio de Janeiro, 1959, p. 68.

SANTOS, Joaquim Ferreira dos. Antônio Maria: noites de Copacabana. Rio de Janeiro: Relume-Dumará, 1ª edição, 1996.

. Um homem chamado Maria. Rio de Janeiro: Objetiva, $1^{\text {a }}$ edição, 2006.

SIMON, Luiz Carlos. "Quando o jornal é a matéria: as crônicas de Antônio Maria". In: Duas ou três páginas despretensiosas: a crônica, Rubem Braga e outros cronistas. Paraná: Eduel, 2011.

SOUSA, Moacir Barbosa de. “Antônio Maria: o 'tomba' cardisplicente”. In: $E o$ rádio? Organização de Luiz Artur Ferraretto e Luciano Klöckner. Porto Alegre: Edipucrs, 2010, pp. 59-76.

ZÉ, Tom. "Secreto ritual amoroso: namorada-radiola". In: Tropicalista lenta luta. São Paulo: Publifolha, 2011, pp. 91-92.

\section{SOBRE CRÔNICA}

A CRÔNICA A PARTIR DE 1930. Estação Literária, v. 11. Londrina: Universidade Estadual de Londrina, jan./jul. 2013.

ARRIGUCCI JR, Davi. “Braga de novo por aqui”. In: Enigma e comentário: ensaios sobre literatura e experiência. São Paulo: Companhia das Letras, $1^{a}$ edição, 1987, pp. 2950.

. "Fragmentos sobre a crônica". In: op. cit., pp. 51-66.

. “Onde andará o velho Braga?”. In: Outros achados e perdidos. São Paulo: Companhia das Letras, $1^{\text {a }}$ edição, 1999, pp. 148-155.

BRAGA, Rubem. "Fala, amendoeira". Diário de Notícias. Rio de Janeiro, 19 set. 1957, Primeira Seção, p. 2.

BROCA, Brito. "Crônica na atualidade literária francesa". O Estado de S. Paulo. São Paulo, 13 set. 1958.

CAMPOS, Gilse. "O território livre da crônica". Jornal do Brasil. Rio de Janeiro, 18 ago. 1973. 
CANDIDO, Antonio (et al.). A crônica: o gênero, sua fixação e suas transformações no Brasil. Campinas: Editora da UNICAMP; Rio de Janeiro: Fundação Casa de Rui Barbosa, $1^{\text {a }}$ edição, 1992.

CANDIDO, Antonio. "A vida ao rés-do-chão". In: Recortes. Rio de Janeiro: Ouro sobre Azul, $3^{\text {a }}$ edição, 2004, pp. 26-34.

. "Dois cronistas". In: Textos de intervenção. São Paulo: Editora 34/Duas Cidades, 2002, pp. 205-210.

. "Drummond prosador". In: Recortes. Rio de Janeiro: Ouro sobre Azul, $3^{\mathrm{a}}$ edição, 2004, pp. 13-23.

; CASTELLO, José Aderaldo. "Rubem Braga". In: Presença da literatura brasileira III: modernismo. São Paulo: Difusão Europeia do Livro, $2^{a}$ edição, 1967, pp. $358-371$.

COUTINHO, Afrânio. "Ensaio e crônica". In: A literatura no Brasil, v. 6. Rio de Janeiro: José Olympio; Niterói: Eduff, 1986.

. "Personalidade da crônica". Diário de Notícias. Rio de Janeiro, 8 dez. 1957, Suplemento Literário, p. 3. O artigo foi recolhido no livro Introdução à literatura no Brasil. Rio de Janeiro: Editora Distribuidora de Livros Escolares LTDA., $1^{a}$ ed., 1975.

DIMAS, Antonio. "Ambiguidade da crônica: literatura ou jornalismo?". In: Revista Littera, $\mathrm{n}^{\mathrm{o}}$ 12, Rio de Janeiro, set.-dez. 1974, pp. 46-51.

FERREIRA, Raquel França dos Santos. "Crônicas, jornais e Rio de Janeiro na década de 1950”. In: Encontro de História Anpuh-Rio. Rio de Janeiro, 2008.

FISCHER, Luís Augusto. “A crônica, prima irmã do ensaio”. In: Inteligência com dor: Nelson Rodrigues ensaísta. Porto Alegre: Arquipélago Editorial, $1^{\text {a }}$ edição, 2009, pp. $65-95$.

GLEDSON, John. “Apresentação”. In: Conversas de burros, banhos de mar e outras crônicas exemplares. Organização de John Gledson. Lisboa: Cotovia, 2006, pp. 11-35.

LIMA, Alceu de Amoroso. Estudos: quinta série. Rio de Janeiro: Civilização Brasileira, 1933, p. 83. 
LINHARES, Temístocles. "Cronistas escritores”. O Estado de S. Paulo, São Paulo, 20 out. 1957. Suplemento Literário, p. 4.

MASSI, Augusto. “Chez Braga”. In: BRAGA, Rubem. Retratos parisienses. Seleção de Augusto Massi. Rio de Janeiro: José Olympio, $1^{\text {a }}$ edição, 2013, pp. 9-22.

OTSUKA, Edu Teruki. “Divagação sobre a crônica”. Inédito, 2010.

PAES, José Paulo. “Crônica”. In: MOISÉS, Massaud; PAES, José Paulo. Pequeno dicionário de literatura brasileira. São Paulo: Cultrix, 1980, pp. 129-131.

PRADO, Décio de Almeida. "Tentativa de crônica sobre Rubem Braga”. In: Seres, coisas, lugares: do teatro ao futebol. São Paulo: Companhia das Letras, $1^{\text {a }}$ edição, 1997, pp. 83-91.

PORTELLA, Eduardo. "A cidade e a letra". In: Dimensões, I. Rio de Janeiro: José Olympio, $1^{\text {a }}$ edição, 1958.

. “Até onde a crônica é literatura?”. Jornal do Brasil. Rio de Janeiro, 13 jan. 1968.

RESENDE, Beatriz (et al). Cronistas do Rio. Rio de Janeiro: José Olympio/CCBB, $1^{\text {a }}$ edição, 1995.

RÓNAI, Paulo. "Um gênero brasileiro: a crônica". In: Crônicas brasileiras: a portuguese reader. Organização de Alfred Hower and Richard A. Preto-Rodas. Flórida: Center for Latin American Studies, University of Florida, 5a edição, 1978.

RONCARI, Luiz. "A estampa da rotativa na crônica literária". In: Boletim Bibliográfico da Biblioteca Mario de Andrade, vol. 46, nº 1-4, jan. dez. 1985, pp. 9-16. . "A crônica: duas ou três coisas que penso dela". Caderno Folhetim da Folha de S.Paulo. São Paulo, 9 jan. 1983.

SÁ, Jorge de. A crônica. São Paulo: Editora Ática, 6ª edição, 2005.

SIMON, Luiz Carlos. Duas ou três páginas despretensiosas: a crônica, Rubem Braga e outros cronistas. Paraná: Eduel, 2011.

SOARES, Marcus Vinicius Nogueira. A crônica brasileira do século XIX: uma breve história. São Paulo: É Realizações, $1^{\text {a }}$ edição, 2014. 
. "Uma flor murcha: a crônica brasileira entre o jornal e o livro". Revista da Anpoll, no 38, Florianópolis, jan./jun., 2015.

WERNECK, Humberto. "Um gênero tipicamente brasileiro". In: Boa companhia: crônicas. Organização de Humberto Werneck. São Paulo: Companhia das Letras, $1^{\text {a }}$ edição, 2005, pp. 7-12.

\section{MÚSICA E AUDIOVISUAL}

A NOITE É UMA CRIANÇA! Um musical de bolso sobre Antônio Maria e as noites de Copacabana. Núcleo Informal de Teatro. Roteiro de Marcos França. Rio de Janeiro: Sala de Som Records, 2008, disco sonoro (44 min.).

BRASILEIRO, PROFISSÃO ESPERANÇA. Com Clara Nunes e Paulo Gracindo. Texto de Paulo Pontes sobre crônicas de Antônio Maria. Direção de Bibi Ferreira. Rio de Janeiro: EMI-Odeon, 1974, disco sonoro (37 min.), 12 polegadas.

ESTÚDIO F. Especial “Antônio Maria”. Roteiro de Cláudio Felício e Luiz Sérgio Lima e Silva. Apresentação de Paulo César Soares. Produção da Funarte e da Rádio Nacional. Rio de Janeiro: Rádio Cultura Brasil, 18 out. 2014. Programa de rádio.

MANSA, Marisa Gata. Encontro com Antônio Maria. Rio de Janeiro: CID, 1997, disco sonoro (48 $\mathrm{min}$.).

MARIA, Antônio. Antônio Maria. Coleção "História da Música Popular Brasileira", v. 36. Produção artística de J. L. Ferrete e Elifas Andreatto. Rio de Janeiro: RCA Victor, 1971, disco sonoro, 10 polegadas (Relançado pela Abril Cultural na coleção "Nova História da Música Popular Brasileira” em 1978, v. 43, 10 polegadas).

; LOBO, Fernando. Antônio Maria \& Fernando Lobo. Coleção "História da Música Popular Brasileira", série "Grandes compositores”, São Paulo: Abril Cultural, 1983, disco sonoro, 12 polegadas.

MEMÓRIA: ANTÔNIO MARIA. Direção de Eloy Santos. Rio de Janeiro: TVE-RJ, 22 dez. 1991. Programa de TV.

PEREIRA, Albuquerque. A vida começa aos oitenta. Documentário sobre a Rádio Clube de Pernambuco. Recife: Rádio Clube de Pernambuco, 1999. 
ABREU, Alzira Alves de. A imprensa em transição: o jornalismo brasileiro nos anos 50. Rio de Janeiro: FGV, 1996.

COSTA, Cecília. Diário Carioca: o jornal que mudou a imprensa brasileira. Rio de Janeiro: Fundação Biblioteca Nacional, 2011.

LOUZADA, Silvana. "Ascensão e queda de O Cruzeiro e Manchete". Observatório da Imprensa, 2003. Disponível em: 〈https://bit.ly/2OlZY4B>. Acesso em 25 fev. 2019.

PINHEIRO JR. A Última Hora (como ela era): história e lenda de uma convulsão jornalística contada por um atuante repórter do jornal de Samuel Wainer. Rio de Janeiro: Mauad X, 2011.

RIBEIRO, Ana Paula Goulart. "Jornalismo, literatura e política: a modernização da imprensa carioca nos anos 1950”. In: Estudos Históricos, v. 1, n. 31. Publicação do Programa de Pós-Graduação em História, Política e Bens Culturais da Escola de Ciências Sociais. Rio de Janeiro: FGV, 2003, pp. 147-160.

SODRÉ, Nelson Werneck. História da imprensa no Brasil. Rio de Janeiro: Mauad, $1^{a}$ edição, 1999.

\section{SOBRE RÁDIO}

AZEVEDO, Lia Calabre de. No tempo do rádio: radiodifusão e cotidiano no Brasil, 1923-1960. Tese (Doutorado em História) - Instituto de História, Universidade Federal Fluminense, 2002.

BESSA, Silvia. "Rádio Clube, a pioneira do Brasil, comemora 100 anos". Diário de Pernambuco. Recife, 06 abr. 2018. Disponível em <https://bit.ly/355VHJi $>$. Acesso em 17 nov. 2019.

. "Nem speaker, nem locutor: falador". Diário de Pernambuco. Recife, 22 ago. 2018. Disponível em 〈https://bit.ly/2urTDPi>. Acesso em 7 fev. 2020.

CABRAL, Sérgio. No tempo do Almirante: uma história do rádio e da МРB. Rio de Janeiro: Francisco Alves, 1990.

Antonio Carlos Jobim: uma biografia. Rio de Janeiro: Lazuli, $1^{\text {a }}$ edição, 2008. 
VIRGILIO, Paulo. "Primeira transmissão de rádio no Brasil completa 90 anos". EBC. Rio de Janeiro, 07 set. 2016. Disponível em 〈https://bit.ly/2qZWaOz〉. Acesso em 17 nov. 2019.

. "Rádio Nacional é invadida por militares por dar voz à resistência ao golpe". EBC. Rio de Janeiro, 31 mar. 2014. Disponível em 〈https://bit.ly/2U6iyAG >. Acesso em 13 mar. 2020.

\section{SOBRE ENGENHOS E USINAS}

ANDRADE, Manuel Correia de. História das usinas de açúcar de Pernambuco. Recife: Fundação Joaquim Nabuco/Massangana, 1989.

BARBOSA, Gladisson. Usinas de Pernambuco. Disponível em <www.usinasdepernambuco.blogspot.com>. Acesso em 6 nov. 2019.

MOURA, Severino. Senhores de engenho e usineiros: a nobreza de Pernambuco. Recife: Fiam/CEHM/Sindaçúcar, 1998.

RODRIGUES, Maria de Lourdes Neves Baptista. Engenhos de Pernambuco. Disponível em: 〈www.engenhosdepernambuco.blogspot.com.br $>$. Acesso em 6 nov. 2019.

\section{TESES E DISSERTAÇÕES}

ANTONIO, Luciano. A cidade nas crônicas de Antônio Maria. 2015. Tese (Doutorado em Letras) - Literatura Brasileira e Outras Literaturas Vernáculas, Universidade Estadual de Londrina, 2015.

BEUCLAIR, Marcelo Gomes. A palavra seduzida: aspectos discursivos na crônica de Joaquim Ferreira dos Santos e Antônio Maria. 2011. Tese (Doutorado em Letras) Instituto de Letras, Universidade Estadual do Rio de Janeiro, Rio de Janeiro, 2011.

FERREIRA, Raquel França dos Santos. Antônio Maria: visões sobre o cotidiano do Rio de Janeiro na década de 1950. 2003. Dissertação (Mestrado em História) Departamento de História, PUC-Rio, Rio de Janeiro, 2003.

GASPAR, Samantha dos Santos. Rubem Braga e o semanário Comício: cidade, política e imprensa no segundo governo Vargas. 2012. Dissertação (Mestrado em 
Antropologia Social) - Faculdade de Filosofia, Letras e Ciências Humanas, Universidade de São Paulo, São Paulo, 2012.

IRENO, Rafael da Cruz. Crônicas da guerra na Itália: estudo sobre o estilo de Rubem Braga e a história dos pracinhas. 2016. Dissertação (Mestrado em Teoria Literária e Literatura Comparada) - Faculdade de Filosofia, Letras e Ciências Humanas, Universidade de São Paulo, São Paulo, 2016

KAMEDA, André Tadao. Rubem Braga nos anos 1950 e 1960: integração nacional, modernização e autonomia da crônica. 2018. Dissertação (Mestrado em Teoria Literária e Literatura Comparada) - Faculdade de Filosofia, Letras e Ciências Humanas, Universidade de São Paulo, São Paulo, 2018.

VONK, Arthur. Ao rés-do-chão, sem chão: Drummond e a crônica moderna brasileira. 2013. Dissertação (Mestrado em Teoria Literária e Literatura Comparada) Faculdade de Filosofia, Letras e Ciências Humanas, Universidade de São Paulo, 2013.

\section{VEÍCULOS DE IMPRENSA}

A NOITE ILUSTRADA (RJ).

A NOITE (RJ).

CIDADE DO SALVADOR (BA).

COMÍCIO (RJ).

DIÁRIO CARIOCA (RJ).

DIÁRIO DA NOITE (RJ).

DIÁRIO DE PERNAMBUCO (PE).

FLAN (RJ).

FOLHA DA MANHÃ (PE).

MANCHETE (RJ).

O CRUZEIRO (RJ).

O GLOBO (RJ).

O JORNAL (RJ). 
O MUNDO ILUSTRADO (RJ).

O SEMANÁRIO (RJ).

RADIOLÂNDIA (RJ).

REVISTA DA SEMANA (RJ).

REVISTA DO RÁDIO (RJ).

ÚLTIMA HORA (RJ).

VIDA DOMÉSTICA (RJ).

BIBLIOGRAFIA GERAL

ANDRADE, Carlos Drummond de. Confissões de Minas. São Paulo: Cosac Naify, 2011.

; BANDEIRA, Manuel. O Rio de Janeiro em prosa e verso. Rio de Janeiro: José Olympio, 1965.

ANYSIO, Chico. Sou Francisco. Rio de Janeiro: Rocco, 1ª edição, 1992.

ARRIGUCCI JR, Davi. Humildade, paixão e morte: a poesia de Manuel Bandeira. São Paulo: Companhia das Letras, $2^{\mathrm{a}}$ edição, 2009.

BANDEIRA, Manuel. Poesia completa e prosa. Rio de Janeiro: Nova Aguilar, 2009. . Flauta de papel. Rio de Janeiro: Alvorada, 1ª edição, 1957.

. Crônicas da província do Brasil. Organização de Júlio Castañon Guimarães. São Paulo: Cosac Naify, 2006.

BLOCH, Arnaldo. Os irmãos Karamabloch. São Paulo: Companhia das Letras, $1^{\text {a }}$ edição, 2008.

BRAGA, Rubem. Ai de ti, Copacabana. Rio de Janeiro: Editora do Autor, $1^{\text {a }}$ edição, 1960.

CANDIDO, Antonio. “A Revolução de 1930 e a cultura”. In: A educação pela noite. Rio de Janeiro: Ouro sobre Azul, 6 ${ }^{\text {a }}$ edição, 2011, pp. 219-241.

. Literatura e sociedade: estudos de teoria e história literária. Rio de Janeiro: Ouro sobre Azul, 11 a edição, 2010. 
. "Ficção e confissão". In: Ficção e confissão: ensaios sobre Graciliano Ramos. Rio de Janeiro: Ouro sobre Azul, $3^{\text {a }}$ edição, 2006.

CARDOSO, Ivan. "Entrevista com João Cabral de Melo Neto". Caderno Folhetim da Folha de S.Paulo. São Paulo, 24 abr. 1987.

CARVALHO, Arthur. "Manquitolando II". In: A menina e o gavião: 200 crônicas escolhidas. Recife: Cepe, 2015, pp. 371-372.

CARVALHO, Marco Antonio de. Rubem Braga: um cigano fazendeiro do ar. São Paulo: Biblioteca Azul, 2a edição, 2013.

CASTELlO, José. Vinicius de Moraes: o poeta da paixão. São Paulo: Companhia das Letras, $1^{\text {a }}$ edição, 1994.

CASTRO, Ruy. Chega de saudade: a história e as histórias da Bossa Nova. São Paulo: Companhia das Letras, $1^{\text {a }}$ edição, 1990.

. A noite do meu bem: a história e as histórias do samba-canção. São Paulo: Companhia das Letras, $1^{a}$ edição, 2015.

Querido poeta: correspondência de Vinicius de Moraes. São Paulo: Companhia das Letras, 2003, pp. 214-216 e pp. 243-244.

O anjo pornográfico: a vida de Nelson Rodrigues. São Paulo: Companhia das Letras, 1994.

CAYMMI, Stella. Dorival Caymmi: o mar e o tempo. São Paulo: Editora 34, $1^{\text {a }}$ edição, 2001.

COLEÇÃO REVISTA DA MÚSICA POPULAR. Rio de Janeiro: Funarte/Bem-te-vi, $1^{\mathrm{a}}$ edição, 2006.

ENCICLOPÉDIA DA MÚSICA BRASILEIRA. São Paulo: Art Editora; Publifolha, $3^{\mathrm{a}}$ edição, 2000.

FAOUR, Rodrigo. Angela Maria: a eterna cantora do Brasil. São Paulo: Record, $1^{\text {a }}$ edição, 2015.

GASPARI, Elio. A ditadura envergonhada. São Paulo: Companhia das Letras, 2002. 
HARAZIM, Dorrit. “Chegou o verão”. Piauí, n. 27. São Paulo, dez. 2008. Disponível em: 〈https://bit.ly/3bHLSUN>. Acesso em 16 mai. 2020.

LACERDA, Carlos. Depoimento. Rio de Janeiro: Nova Fronteira, $3^{\text {a }}$ edição, 2007.

LAFETÁ, João Luiz. 1930: a crítica e o Modernismo. São Paulo: Duas Cidades; Editora 34, $2^{a}$ edição, 2000.

. “Estética e ideologia: o Modernismo em 30”. In: A dimensão da noite.

Organização de Antonio Arnoni Prado. São Paulo: Duas Cidades/Editora 34, $1^{\text {a }}$ edição, 2004.

LAGO, Mário. Bagaço de beira-estrada. Rio de Janeiro: José Olympio, $1^{\text {a }}$ edição, 2012.

LEAL, Claudio. "Riachão, o sambista feliz". Terra Magazine. São Paulo, 26 out. 2008.

LEÃO, Danuza. Quase tudo. São Paulo: Companhia das Letras, $1^{\text {a }}$ edição, 2005.

LOBO, Fernando. À mesa do Vilariño. Rio de Janeiro: Record, $1^{\text {a }}$ edição, 1991.

MARQUES, Ivan Francisco. "Confissões de Minas e Passeios na ilha, de Carlos Drummond de Andrade”. Remate de Males v. 31, n. 1-2, 2012, pp. 361-367.

MATOS, Maria Izilda Santos de. Dolores Duran: experiências boêmias em Copacabana nos anos 50. Rio de Janeiro: Bertrand Brasil, $1^{\text {a }}$ edição, 1997.

MELLO, Zuza Homem de. Copacabana: a trajetória do samba-canção (1929-1958). São Paulo: Editora 34/Edições Sesc, 1ª edição, 2017.

MESQUITA, Cláudia. De Copacabana à Boca do Mato: o Rio de Janeiro de Sérgio Porto e Stanislaw Ponte Preta. Rio de Janeiro: Edições Casa de Rui Barbosa, 2008.

MONTEIRO, Karla. Samuel Wainer: o homem que estava lá. São Paulo: Companhia das Letras, $1^{\text {a }}$ edição, 2020.

MORAIS, Fernando. Chatô: o rei do Brasil. São Paulo: Companhia das Letras, $1^{\text {a }}$ edição, 1994.

NETO, João Cabral de Melo. Obra completa. Organização de Marly de Oliveira. Rio de Janeiro: Nova Aguilar, 1994. 
OLIVEIRA, Francisco de. "Nordeste: a invenção pela música". In: Decantando a República: inventário histórico e político da canção popular brasileira. Vol. 3: “A cidade não mora mais em mim”. Organização de Berenice Cavalcante, Heloisa Starling e José Eisenberg. Rio de Janeiro: Nova Fronteira; São Paulo: Fundação Perseu Abramo, 2004.

OLIVEIRA, José Carlos. Diário da patetocracia: crônicas brasileiras, 1968. Rio de Janeiro: Graphia, $1^{\mathrm{a}}$ edição, 1995.

PHAELANTE, Renato. MPB - Compositores pernambucanos. Coletânea bio-músicofonográfica: 100 anos de história. Recife: Cepe, $1^{\text {a }}$ edição, 2010.

PITOL, Sergio. El arte de la fuga. Barcelona: Anagrama, 1ª edição, 1997.

PORTO, Sérgio. O homem ao lado. Rio de Janeiro: José Olympio, 1ª edição, 1958.

RAMOS, Guerreiro. Introdução crítica à sociologia brasileira. Rio de Janeiro: Editorial ANDES Limitada, 1ª edição, 1957, p. 184.

RESENDE, Beatriz. Lima Barreto e o Rio de Janeiro em fragmentos. Belo Horizonte: Autêntica Editora, 2a edição, 2016.

RIO, João do. A alma encantadora das ruas. Organização de Raúl Antelo. São Paulo: Companhia das Letras, $1^{\text {a }}$ edição, 2008.

RODRIGUES, Nelson. A vida como ela é... Rio de Janeiro: Nova Fronteira, $3^{\text {a }}$ edição, 2012.

SABINO, Fernando. O tabuleiro de damas. Rio de Janeiro: Record, $2^{\text {a }}$ edição, 1999.

SIMAS, Luiz Antonio. O corpo encantado das ruas. Rio de Janeiro: Civilização Brasileira, $4^{\mathrm{a}}$ edição, 2020.

SOARES, Jô. O livro de Jô: uma autobiografia desautorizada, v. 1. São Paulo: Companhia das Letras, $1^{\text {a }}$ edição, 2017.

VENTURA, Zuenir. Cidade partida. São Paulo: Companhia das Letras, $1^{\text {a }}$ edição, 1994.

WAINER, Samuel. Minha razão de viver: memórias de um repórter. Rio de Janeiro: Record, $1^{\text {a }}$ edição, 1988. 